Historic, Archive Document

Do not assume content reflects current scientific knowledge, policies, or practices. 


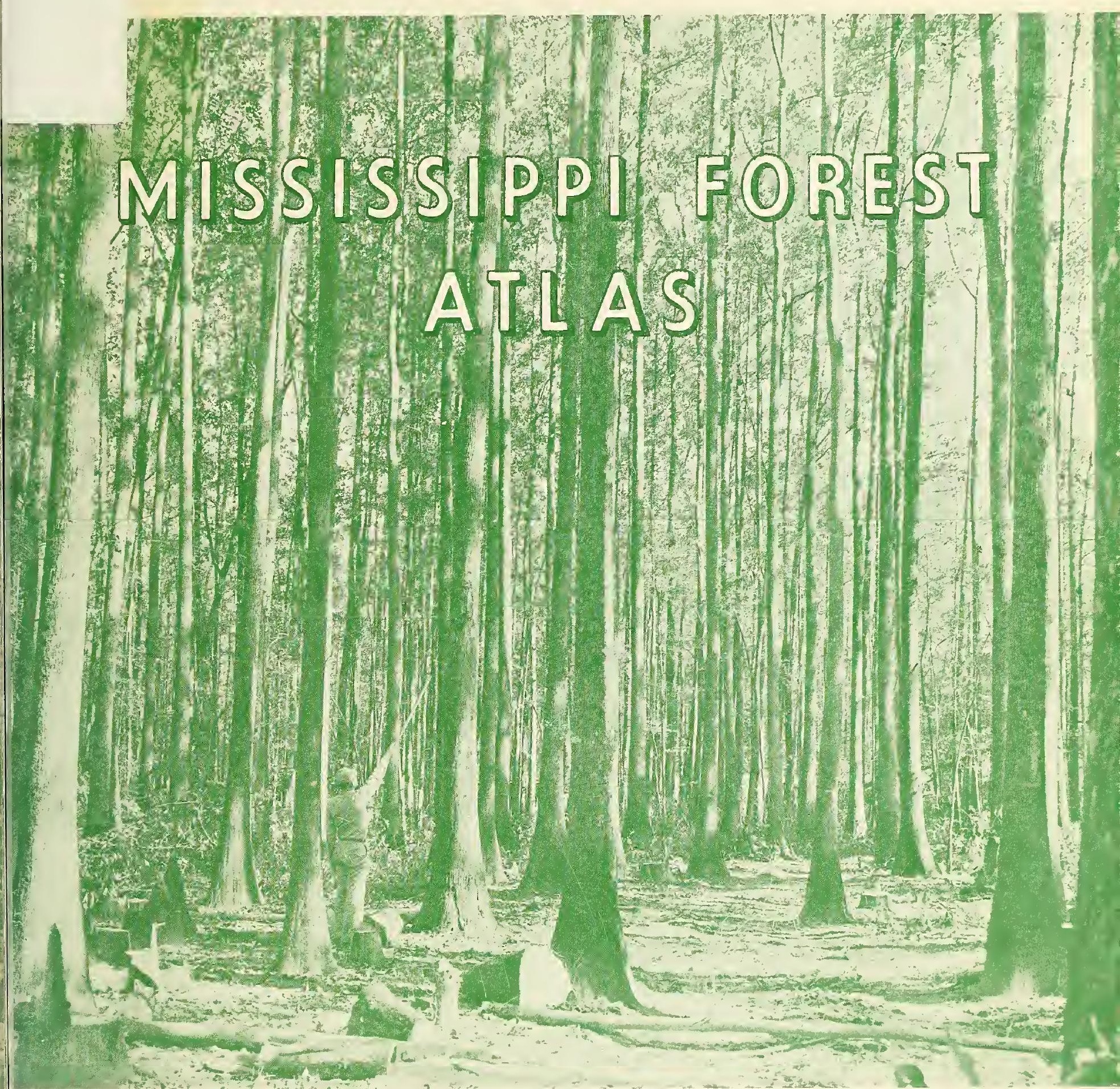

Prepared by

SOUTHERN FOREST EXPERIMENT STATION

FOREST SERVICE, U.S.DEPT. OF AGRICULTURE

for the

MISSISSIPPI INDUSTRIAL AND TECHNOLOGICAL RESEARCH COMMISSION 


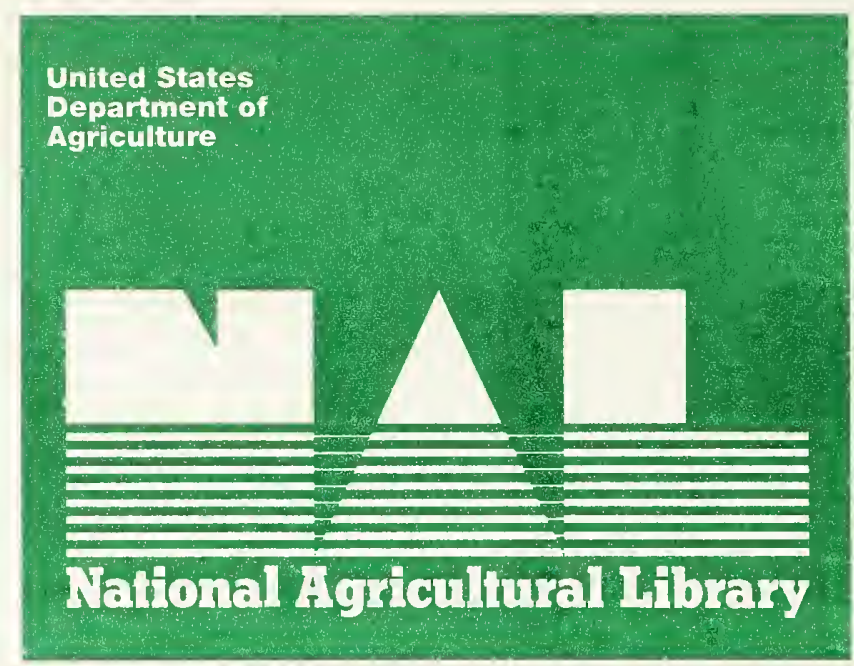

This Small Business study, "Mississippi Forest Atlas," has been conducted and prepared under the direction of Director Henry H. Leveck, Project Supervisor for Mississippi State University, and Dr. A. D. Suttle, Jr., Project Director for Mississippi Industrial and Technological Research Commission.

The research was financed by a grant made by the Small Business Administration, United States Government, under the authority of Public Law 699 (85th Congress).

Only a limited number of copies of this report have been printed. It is available for reference in any of the Small Business Administration offices throughout the United States or at many reference libraries. Copies of the report also may be obtained without charge directly from Mississippi Agricultural Experiment Station, State College, Mississippi.

Summaries of this study are being printed and will be available in reasonable quantities. These summaries may be secured from SBA field offices or from the Small Business Administration, Washington 25, D. C.

The Small Business Administration assumes no responsibility for the accuracy of the data contained herein, nor does it necessarily endorse any opinions, conclusions, or recommendations which may be a part of this report.

John E. Horne

Administrator

Smail Business Administration 


\section{MISSISSIPPI FOREST ATLAS}

Herbert S. Sternitzhe

Prepared by

SOUTHERN FOREST EXPERIMENT STATION

under a Small Business Administration grant

awarded to the

MISSISSIPPI INDUSTRIAL AND TECHNOLOGICAL RESEARCH COMMISSION

Project Director

H. H. LEVECK

Director, Mississippi Agricultural Experiment Station 



\section{Contents}

Mississippi forests: an industrial resource

Timber resources _- 1

Opportunities for forest industry expansion

Accuracy of the survey _._- 4

Definitions of terms

Forest resource maps

1. Commercial forest land

2. Major forest-type groups

3. Change in commercial forest area, 1948-57 10

4. Forest-industry ownership 11

5. Change in number of growing stock trees, 1948-57

6. Pine sawtimber

7 Ash sawtimber 14

8. Cottonwood sawtimber

9. Willow sawtimber 16

10. White elm sawtimber 17

11. Tupelo and blackgum sawtimber

12. Sweetgum sawtimber 19

13. Hickory sawtimber 20

14. Pecan sawtimber

15. Sweetbay and magnolia sawtimber 22

16. Yellow-poplar sawtimber

17. Red oak sawtimber - 24

18. White oak sawtimber

19. Hackberry sawtimber

20. Sycamore sawtimber

21. Beech sawtimber 28

22. Hardwood sawtimber in standard factory lumber logs ____ 29

23. Average volume per acre of pine sawtimber in softwood types _- 30

24. Average volume per acre of hardwood sawtimber in softwood types

25. Average sawtimber volume per acre in hardwood types

26. Relationship of growth and cut of softwood sawtimber 33

27. Relationship of growth and cut of hardwood sawtimber

28. Output of pine pulpwood, 1959

29. Output of industrial softwood (except pulpwood), 1959

30. Output of hardwood pulpwood, 1959

31 . Output of industrial hardwood (except pulpwood), 1959

Tables _- 39

1. Sawtimber volume by species ..._. 1

2. Growing stock volume by species group and county 40

3. Growing stock volume by diameter group and county _.__ 42

4. Sawtimber volume by species group and county _.__ 44

5. Sawtimber volume by diameter group and county _-_____ 46

6. Land area and commercial forest by county 48 


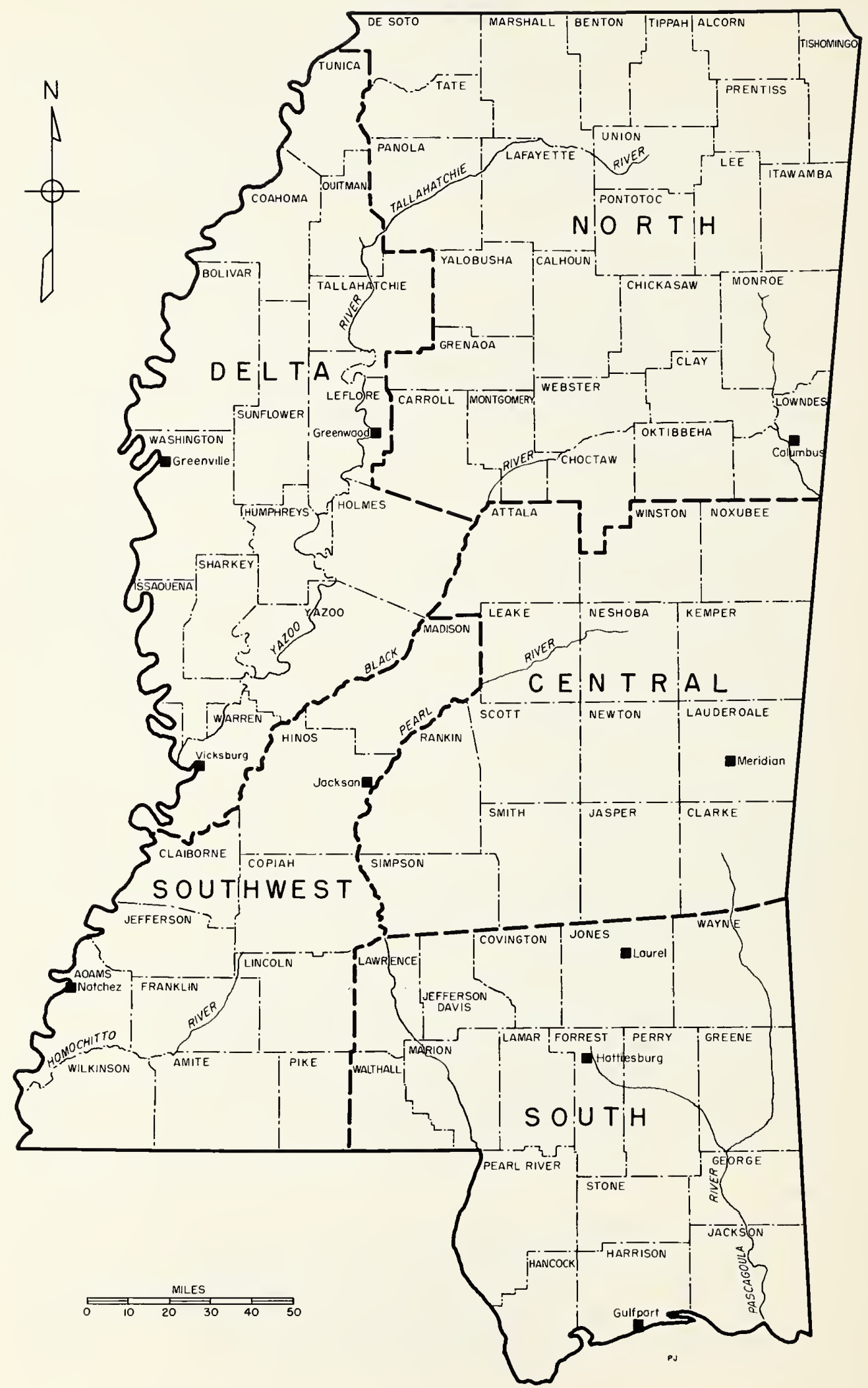

Forest Survey regions in Mississippi. 


\section{Mississippi Forests: An Industrial Resource}

In the search for resources to support industrial expansion in Mississippi, it is logical to turn to the forests. The area occupied by forests in Mississippi exceeds the combined acreage in all other land uses. Each year tremendous quantities of pine and hardwood are taken from these forests and made into a wide variety of products.

This report provides information to assist managers of wood-using industries and consulting foresters in appraising locations and categories of standing timber that may offer possibilities for development. It is based mainly upon data gathered during the most recent Forest Survey of Mississippi, which was completed in 1957 by the Southern Forest Experiment Station. It also draws upon the previous survey of 1948 in order to show the changes that have been occurring. The information is largely in the form of generalized maps that describe various aspects of the forest situation, such as the geographic distribution of timber volume, woodland area, and output of timber products.

\section{TIMBER RESOURCES}

Forests predominantly of longleaf and slash pine characterize the lower Coastal Plain and comprise 2 million of Mississippi's 17.2 million woodland acres. Extending north from the coastal region, loblolly and shortleaf pine cover 4.6 million acres. Another 2.7 million acres of uplands are occupied by oak, hickory, and other hardwoods in mixture with various pines. In the Delta and along rivers and streams throughout the State are stands of bottom-land hardwoods that aggregate 3.8 million acres. Upland hardwood forests, largely concentrated in a zone bordering the eastern edge of the Mississippi River alluvial plain, total 4.1 million acres.
As is shown in table 1, pine makes up 51 percent of the sawtimber inventory in Mississippi forests. Other softwoods-cypress and redcedar-total scarcely 2 percent. Of the hardwood volume, oaks account for 36 percent, gums 27 percent, hickories 9 percent; and the remaining 28 percent consists of other hardwoods, with yellow-poplar, elm, cottonwood, magnolia, willow, ash, beech, sycamore, and hackberry ranking in the order named.

Table 1. Sawtimber volume by species

\begin{tabular}{l|c}
\hline \multicolumn{1}{c|}{ Species } & Volume \\
\hline & Million board feet \\
Pine & $12,972.3$ \\
Other sof twoods & 565.1 \\
Red oaks & $2,544.6$ \\
White oaks & $1,730.0$ \\
Pecan & 354.7 \\
Other hickories & 781.0 \\
Sweetgum & $1,934.8$ \\
Tupelo and blackgum & $1,318.2$ \\
Cottonwood & 453.5 \\
Willow & 318.5 \\
Soft maples & 89.5 \\
Yellow-poplar & 498.9 \\
Sweetbay and magnolia & 327.6 \\
White elm & 258.9 \\
Other elms & 228.1 \\
Ash & 271.8 \\
Hackberry & 161.7 \\
Beech & 241.5 \\
Sycamore & 240.5 \\
Other hardwoods & 255.5 \\
Total & $25,546.7$ \\
\hline
\end{tabular}

In general, quality specifications are more demanding for hardwood than for pine. Among the several industrial uses of hardwoods, the manufacture of standard factory lumber predominates. Suitability of logs for this purpose, therefore, may be taken as one measure of the 
variability as well as the utility of the current hardwood inventory.

Nearly 9 billion board feet of Mississippi's standing hardwood is in logs of standard factory lumber grade. Of this, some 30 percent is in grades 1 and 2-the logs most generally in demand by sawmills, veneer plants, and other industries needing clear material. The 6 billion board feet of grade 3 volume simply consist of the lowest grade of logs that are suitable for conversion into standard lumber, in the sense that they are capable of yielding practical proportions of clear cuttings.

These grades, developed by the U.S. Forest Products Laboratory, take into account the diameter, length, and amount of defects in individual logs. ' Studies have shown that they dependably predict the lumber grade outturn of logs of specified grade. For nearly all species tested, the yield of No. 1 Common and better lumber in grade 1 logs varies from 65 to 80 percent; in grade 2 logs from 40 to 64 percent; and in grade $3 \operatorname{logs}$ from 13 to 36 percent.

The remaining 3 billion board feet of hardwood inventory is in tie and timber logs-logs with so many sound defects that they will not produce worthwhile amounts of clear material, when sawn wholly into lumber. They are presently suited, however, for such uses as heavy structural material, crating, and crossties.

Both the relative density and the dispersion of the timber within the State vary widely by species (see figs. 6-22). Broadly speaking, the greatest concentration of pine sawtimber is in the southeastern and southwestern sections. Among hardwoods, oaks greatly exceed all others not only in volume but in extent of distribution. Hickory, sweetgum, and blackgum also range widely, the latter two attaining their best development in the bottom lands. Yellow-poplar is thinly scattered east of the Delta. Ash and white elm, though widely dispersed, are most common in the western part of the State. Cottonwood, willow, pecan, sycamore, and hackberry are most prominent in the Mississippi River bottoms. Magnolia is found mainly in the southeastern counties, beech, in the southwest.

For detailed specifications of log grades, see Hardwood log grades for standard Iumber: proposals and results. U.S. Forest Serv. Forest Prod. Lab. Rpt. D1737. 1949.
That Mississippi timber is suitable for many useful and marketable products is partly demonstrated by the number and variety of timberconnected industries operating in the Stateabout 1,000 sawmills, 7 woodpulp mills, and some 100 other plants manufacturing such items as veneer, cooperage, poles, handle stock, shuttle blocks, furniture dimension, and charcoal.

\section{OPPORTUNITIES FOR FOREST INDUSTRY EXPANSION}

What about opportunities for new industrial development based upon utilization of current timber resources?

Pulp and paper is presently the fastest growing segment of Mississippi's forest industry. In response to plant expansion within the State and in peripheral areas, pulpwood production (mainly pine) has risen to 2 million cords annually; 25 years ago the State's output was less than 300,000 cords. Opportunities for further increasing the pulpwood cut are promising. Not only is pine in measurably greater supply today than it was a decade ago, but current growth is well in excess of the annual harvest. Moreover, a 75-percent increase since 1948 in numbers of pines 2 to 4 inches in diameter points to further improvement in pulpwood supplies, if fire protection and other essential forestry programs are continued and strengthened.

Mississippi is also a top-ranking producer of southern pine poles. Most of the annual pole harvest is shipped to the 16 pressure treating plants in the State: One recent study indicated that more than two-thirds of the poles received at treating plants in the South are 16 to 35 feet in length. These lengths can be readily cut from pines 8 to 20 inches in diametersize classes that are now increasing in number in Mississippi. Nationwide, the number of utility poles in service has been rising and is expected to increase further. Too, in recent years a growing market has developed for poles used in barns, storage sheds, and other types of structures. Though demand for poles is expected to heighten, it will probably be met by greater output from existing firms rather than by new installations.

For the immediate future, possibilities for development of new industry based upon pri- 
mary conversion of sawtimber are obviously more limited for hardwood than for pine, in view of the heavy use already being made of such material. Nevertheless there are still localities where some slack can be found.

In the north Mississippi area embracing Calhoun, Itawamba, Lafayette, Lee, Marshall, Tate, Tippah, Tishomingo, and Union Counties, hardwood sawtimber volume has increased some 36 percent since 1948. More than half of the 2.9 million acres in these nine counties is forested. The area, which displays considerable physiographic variation, encompasses some excellent hardwood sites such as the brown loam soils in Lafayette, Tate, and Marshall Counties, as well as the alluvial soils along the Coldwater, Tallahatchie, Yacona, Yalabusha, and other waterways.

The 752 thousand acres of hardwood forests in the 9 counties average 1,300 board feet per acre. But in the bottom lands, which support two-fifths of the hardwood sawtimber, the average is over 2,200 board feet. By way of contrast, the statewide average of bottom-land sawtimber volume is only 1,700 board feet per acre. Of the 1.2 billion board feet of hardwood sawtimber in the 9 counties, 44 percent is oak, 27 percent is gum, and the rest is mainly in a variety of firm-textured species like hickory and ash.

Hardwood sawtimber volume has also risen during the past decade in Forrest, George, Greene, Hancock, Jackson, Pearl River, Perry, and Stone Counties. Forests occupy 78 percent of the 3 million acres of land area in these 8 southeast counties. Hardwood sawtimber volume-up 46 percent since 1948-now totals one billion board feet; two-thirds is on the 325 thousand acres of bottom-land forests, which average 2,400 board feet per acre. The bottoms are chiefly along the Pearl and Pascagoula Rivers and their tributaries.

The hardwood volume in the southeast is predominantly in soft-textured species that are suitable for conversion into veneer as well as lumber. Some 45 percent of the volume is gum, 26 percent other soft-textured species, and 29 percent firm-textured species, largely red oak.

The ownership pattern of the 8-county hardwood resource affords an indication of its relative availability. Some 9 percent of the volume is on public lands (chiefly national forest), while 13 percent is on forest industry holdings, and 78 percent on other types of private ownerships. Except for a somewhat lower proportion of public stumpage, this ownership pattern is much like that of the 9-county area cited earlier.

In sections where hardwoods are already being heavily used, near-term expanion of wood-using industry can come in part through more intensive utilization of the available raw material. Where it can be done economically, one means is by increasing secondary manufacture, so as to produce more finished products. Another is by making use of lower quality timber and perhaps of the leavings of sawmills, planing mills, and other plants.

Long-range possibilities for growth in secondary industry appear favorable. The movement, in fact, is already under way. Primary manufacturers have advanced it in the process of diversification and in undertaking further manufacture of their products. Independent secondary manufacture, too, has expanded, as witness the growth of the furniture industry at New Albany, Tupelo, Okolona, Eupora, Leland, Meridian, and elsewhere.

In conjunction with the expansion of the State's furniture industry, the particle-board market gives promise of continuing to grow. Manufacture of particle board involves mixing small fractions of wood with resins and compressing the mixture into boards of various thicknesses. These boards, which can be made from available low-grade hardwood, are used for a number of purposes, including wall panelling and core stock for furniture.

Basic to the security and expansion of both primary and secondary manufacture is good management of the timber resource. In anticipation of greater long-term demand for timber, pine management programs have already been expanded and intensified in many parts of the State, especially on forest-industry lands and public holdings. An additional motivation for the programs on industrial ownerships is the need for assured supplies of raw material to protect capital investments. Both public agencies and forest industries are also sponsoring programs of technical assistance to stimulate forestry on small ownerships. Although management is progressing more rapidly in pine 
than in hardwoods, educational efforts are developing a wider appreciation of the outstanding opportunities for managing industrial hardwoods on suitable sites. The recent increase in demand for pulping hardwoods may stimulate management too.

Mississippi's forest soils have the capacity to produce a much greater volume of wood than they are currently growing. It can be reasonably assumed that, with application of minimum forestry practices on all commercial timberlands, net annual growth might be raised eventually from 0.5 cord per acre to nearly 1 cord. This would permit the State to enjoy an even greater forest industry than it now does. A still higher average growth can probably be attained under intensive management. The prescription for continued forward movement includes minimizing wildfire, restocking idle land, and removing trees that have little or no utility. Given good timber resources, wood-using industry will thrive, and the two will perpetuate each other.

\section{ACCURACY OF THE SURVEY}

The data on forest acreage and timber volume in this report were secured in 1956-57 with a systematic sampling method involving a forestnonforest classification on aerial photographs and on-the-ground measurements of trees at sample points. The sample points were taken in pairs at and near the intersections of a grid of lines spaced 3 miles apart. Tally trees were selected with a 3.03 diopter prism.

Accuracy of the estimates may be affected by two types of errors. The first stems from the use of a sample to estimate the whole and from variability of the items being sampled. This type is termed sampling error; it is susceptible to a mathematical evaluation of the probability of error. The second type-often referred to as reporting or estimating errorderives from mistakes in measurement, judgment, arithmetic, or recording, and limitations of method or equipment. Effects cannot be appraised mathematically, but the Forest Survey constantly attempts to hold such error to a minimum by proper training and good supervision, and by emphasis on careful work.

Statistical analysis of the data indicates a sampling error of plus or minus 0.3 percent for the estimate of total forest area, 1.4 percent for total cubic volume, and 1.9 percent for total board-foot volume. When acreage and volume totals for the State are broken down by county and other subdivisions of the data, the possibility of error increases and is greatest for the smallest items. The order of this increase is suggested in the following tabulation, which shows the sampling error to which the estimates are liable two chances out of three.

\begin{tabular}{|c|c|c|c|c|c|}
\hline \multicolumn{2}{|c|}{ Forest area } & \multicolumn{2}{|c|}{ Cubic volume } & \multicolumn{2}{|c|}{ Board-foot volume } \\
\hline $\begin{array}{c}\text { Size of area } \\
\text { sampled }\end{array}$ & $\begin{array}{c}\text { Sampling } \\
\text { error }^{1}\end{array}$ & \begin{tabular}{|c|} 
Volume \\
sampled
\end{tabular} & $\begin{array}{c}\text { Sampling } \\
\text { error }\end{array}$ & $\begin{array}{l}\text { Volume } \\
\text { sampled }\end{array}$ & $\begin{array}{c}\text { Sampling } \\
\text { error }\end{array}$ \\
\hline $\begin{array}{c}\text { Thousand } \\
\text { acres }\end{array}$ & Percent & $\begin{array}{c}\text { Million } \\
\text { cu. ft. }\end{array}$ & Percent & $\begin{array}{c}\text { Million } \\
b d . f t .\end{array}$ & Percent \\
\hline 17,000 & 0.3 & 7,600 & 1.4 & 26,000 & 1.9 \\
\hline 10,000 & .4 & 6,000 & 1.6 & 20,000 & 2.1 \\
\hline 5,000 & .6 & 3,000 & 2.2 & 10,000 & 3.0 \\
\hline 2,000 & .9 & 1,000 & 3.8 & 5,000 & 4.3 \\
\hline 500 & 1.8 & 500 & 5.5 & 2,000 & 6.8 \\
\hline 100 & 3.9 & 100 & 12.2 & 300 & 17.5 \\
\hline
\end{tabular}

${ }^{1}$ By random-sampling formula.

2 Estimated by use of a procedure described by D. B. DeLury in Values and Integrals of the orthogonal Polynomials up to $\mathrm{n}=26$. Univ. Toronto Press, $33 \mathrm{pp}$. Toronto, Ont. 1950 .

County data on timber volumes have been included in the report in order to permit adding counties totalling enough volume to meet a desired degree of reliability. To obtain an estimate of growing stock with a sampling error of plus or minus 10 percent, data for enough counties must be added together to total about 150 million cubic feet. A comparable sampling error for sawtimber volume requires about 1,000 million board feet.

\section{DEFINITIONS OF TERMS}

\section{Forest Land Class}

Forest land.-Includes: (a) land which is at least 10 percent stocked by trees of any size and capable of producing timber or other wood products, or of exerting an influence on the climate or on the water regime; (b) land from which the trees have been removed to less than 10 percent stocking and which has not been developed for other use; (c) afforested areas.

Commercial forest land.-Forest land which is (a) producing, or is physically capable of producing, usable crops of wood (usually sawtimber), (b) economically available now or prospectively, and (c) not withdrawn from timber utilization. 
Noncommercial forest land.-Forest land (a) withdrawn from timber utilization through statute, ordinance, or administrative order but which otherwise qualifies as commercial forest land, and ( $b$ ) incapable of yielding usable wood products (usually sawtimber) because of adverse site conditions, or so physically inaccessible as to be unavailable economically in the foreseeable future.

\section{Tree Species}

Commercial species.-Includes species that normally have value for commercial timber products; excludes so-called weed or noncommercial species such as blackjack oak, scrub post oak, blue beech, and sourwood.

Softwoods.-Coniferous species, of which the most numerous are loblolly pine (Pinus taeda), shortleaf pine ( $P$. echinata), and longleaf pine ( $P$. palustris).

Hardwoods.-Broadleaved species, of which the most numerous are the oaks (Quercus spp.) and sweetgum (Liquidambar styraciflua).

\section{Softwood Forest Types}

Longleaf-slash pine.-Forests in which 50 percent or more of the stand is longleaf or slash pine, singly or in combination. Common associates include other southern pines, oak, and gum.

Loblolly-shortleaf pine.-Forests in which 50 percent or more of the stand is loblolly pine, shortleaf pine, or other southern yellow pines excepting longleaf or slash pine, singly or in combination. Common associates include oak, hickory, and gum.

Oak-pine.-Forests in which 50 percent or more of the stand is hardwoods, usually upland oaks, but in which southern pines make up 25-49 percent of the stand. Common associates include gum, hickory, and yellow-poplar.

\section{Hardwood Forest Types}

Oak-hickory.-Forests in which 50 percent or more of the stand is upland oaks or hickory, singly or in combination, except where pines comprise 25-49 percent in which case the stand would be classified oak-pine. Common associates include yellow-poplar, elm, maple, and black walnut.

Oak-gum-cypress.-Bottom-land forests in which 50 percent or more of the stand is tu- pelo, blackgum, sweetgum, oaks, or southern cypress, singly or in combination, except where pines comprise 25-49 percent, in which case the stand would be classified oak-pine. Common associates include cottonwood, willow, ash, elm, hackberry, and maple.

Elm-ash-cottonwood.-Forests in which 50 percent or more of the stand is elm, ash, or cottonwood, singly or in combination. Common associates include willow, sycamore, beech, and maple.

\section{Diameter}

D.b.h. (Diameter breast high).-Tree diameter in inches, outside bark, measured at 4-1/2 feet above ground.

Diameter class.- The 2-inch diameter classes extend from 1.0 inch below to 0.9 inch above the stated midpoint. Thus, the 12 -inch class takes in trees 11.0 inches to and including 12.9 inches d.b.h.

\section{Class of Timber}

Sawtimber trees.-Live trees of commercial species, at least 9.0 inches d.b.h. in softwoods and 11.0 inches d.b.h. in hardwoods, and containing at least a 12-foot merchantable butt log-or, if the butt $\log$ is a cull, at least 50 percent of the gross sawlog volume is in merchantable logs. To be merchantable, a log must meet the following requirements:

(a) In softwoods, logs that have a minimum 6-inch small-end diameter inside bark and that are at least one-third sound, with sweep or crook not exceeding twothirds the small-end diameter.

(b) In hardwoods, logs that have a minimum 8-inch small-end diameter inside bark and that meet the specifications of a standard lumber log or a tie and timber log.

Poletimber trees.-Trees of commercial species which meet regional specifications of soundness and form, and which are of the following diameters at breast height: softwoods 5.0 to 9.0 inches, hardwoods 5.0 to 11.0 inches. Such trees will usually become sawtimber trees if left to grow.

Seedling and sapling trees.-Live trees of commercial species less than 5.0 inches in 
diameter at breast height and of good form and vigor.

Cull trees.- Live trees of sawtimber or poletimber size that are unmerchantable for sawlogs now or prospectively because of defect, rot, or species.

\section{Volume}

Sawtimber volume.-Net volume in board feet, International 1/4-inch rule, of live sawtimber trees to a specified merchantable top.

Growing stock.-Net volume in cubic feet of live sawtimber and live poletimber trees from stump to a minimum 4.0-inch top diameter (of central stem) inside bark.

\section{Miscellaneous Definitions}

Net annual growth of sawtimber.-The change, resulting from natural causes, in net board-foot volume of live sawtimber on commercial forest land during a specified year.

Net annual growth of growing stock.-The change, resulting from natural causes, in net cubic-foot volume of growing stock on commercial forest land during a specified year.

Annual cut of sawtimber.-The net boardfoot volume of live sawtimber trees cut or killed by logging, and by cultural operations, on commercial forest land during a specified year.

Annual cut of growing stock.-The net cubicfoot volume of live sawtimber and poletimber trees cut or killed by logging, or by cultural operations, on commercial forest land during a specified year.

Timber products output.-The volume of timber products cut from both growing stock and other sources. 
Forest Resource Maps 


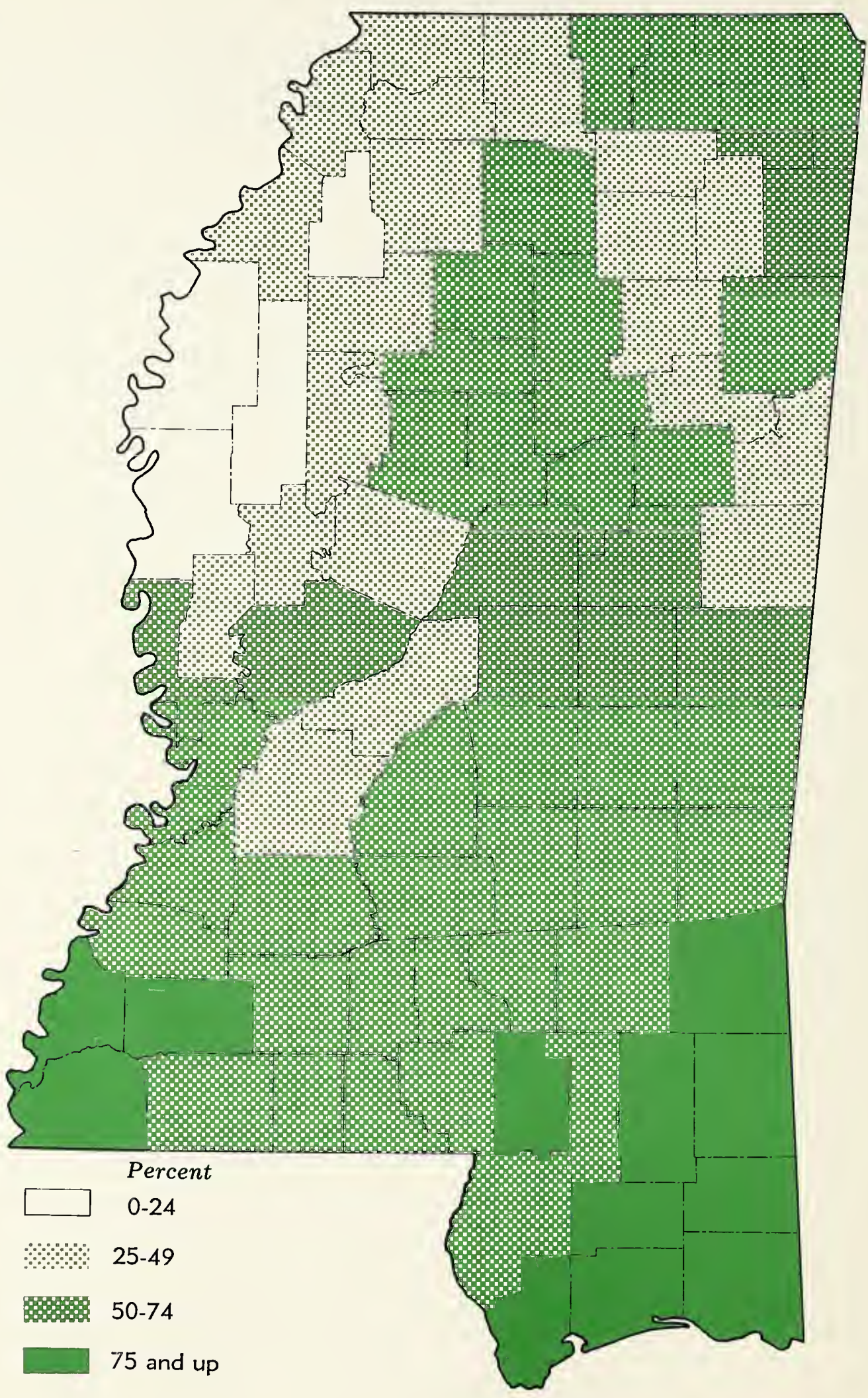

Figure 1. Proportion of commercial forest land. 


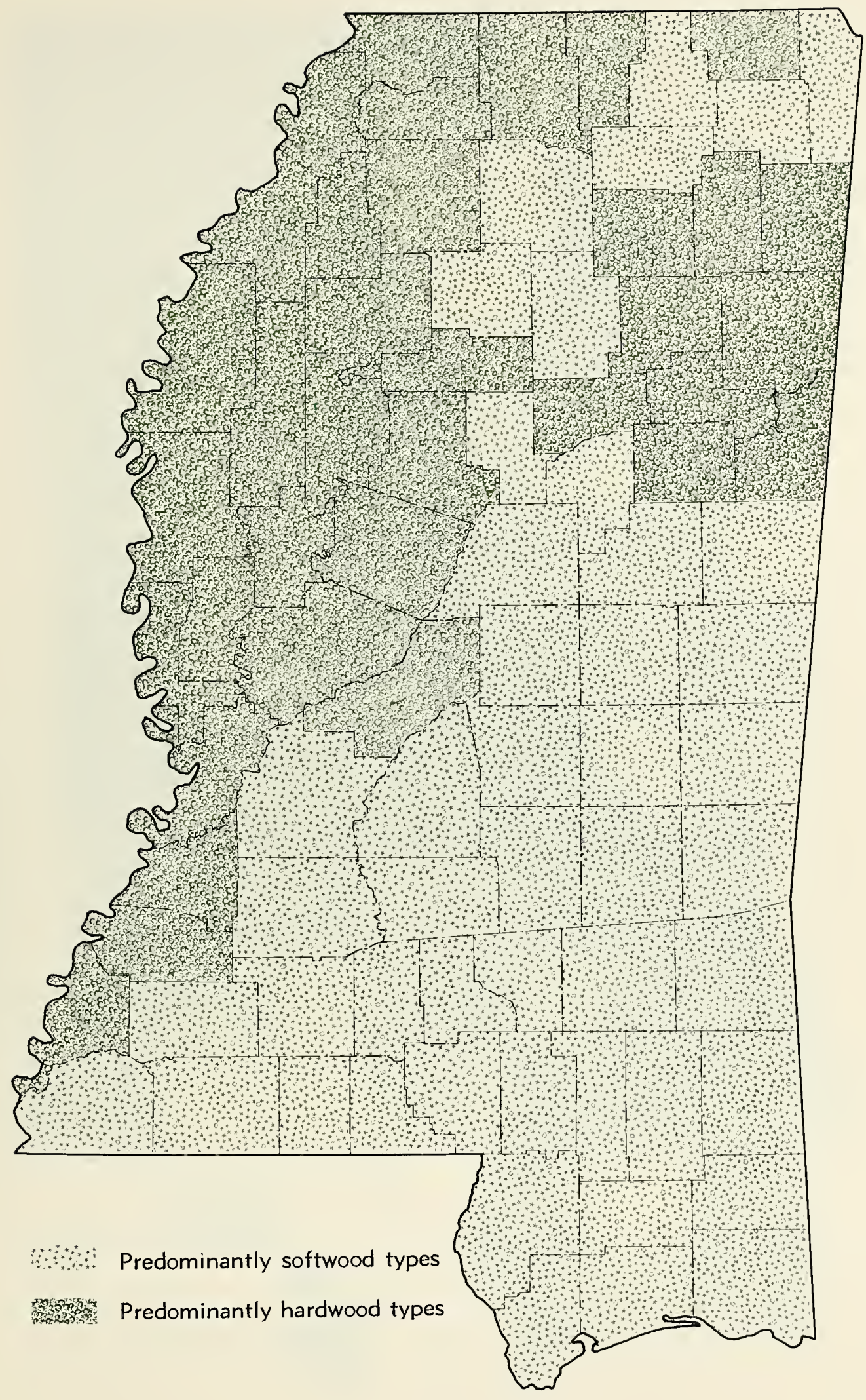

Figure 2. Distribution of major forest-type groups. 


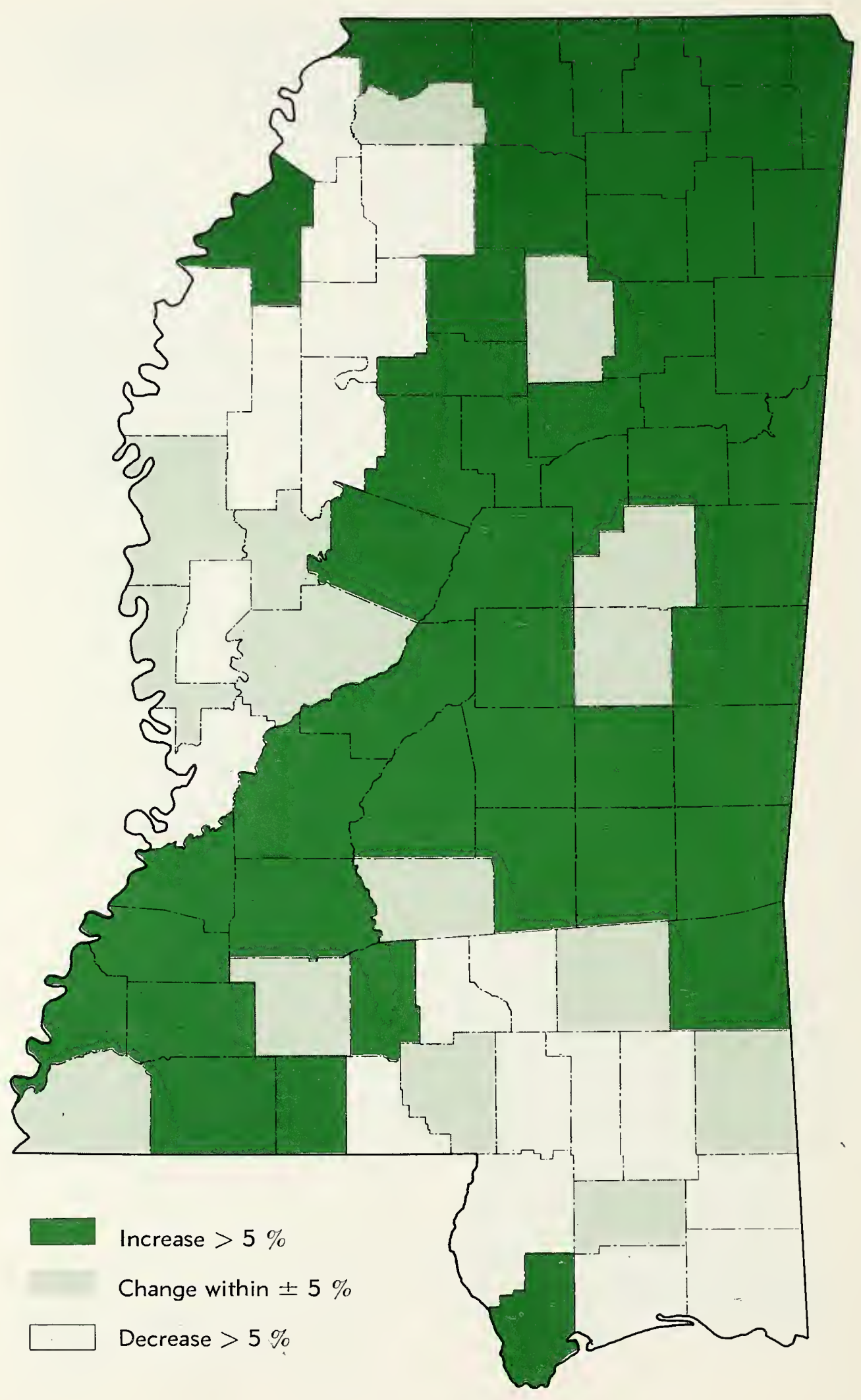

Figure 3. Change in commercial forest area between surveys (1948-57). 


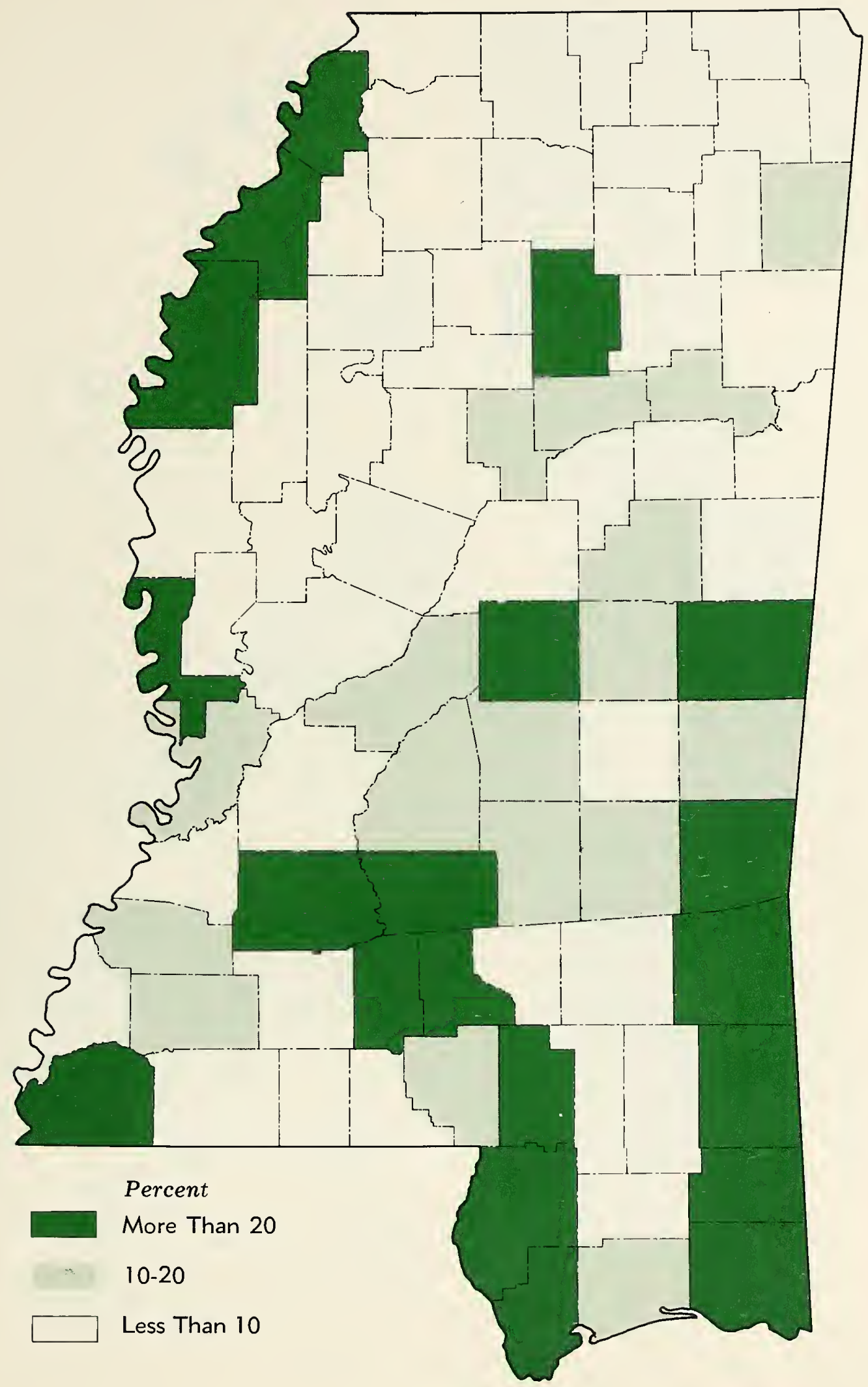

Figure 4. Proportion of commercial forest land in forest industry ownership. 


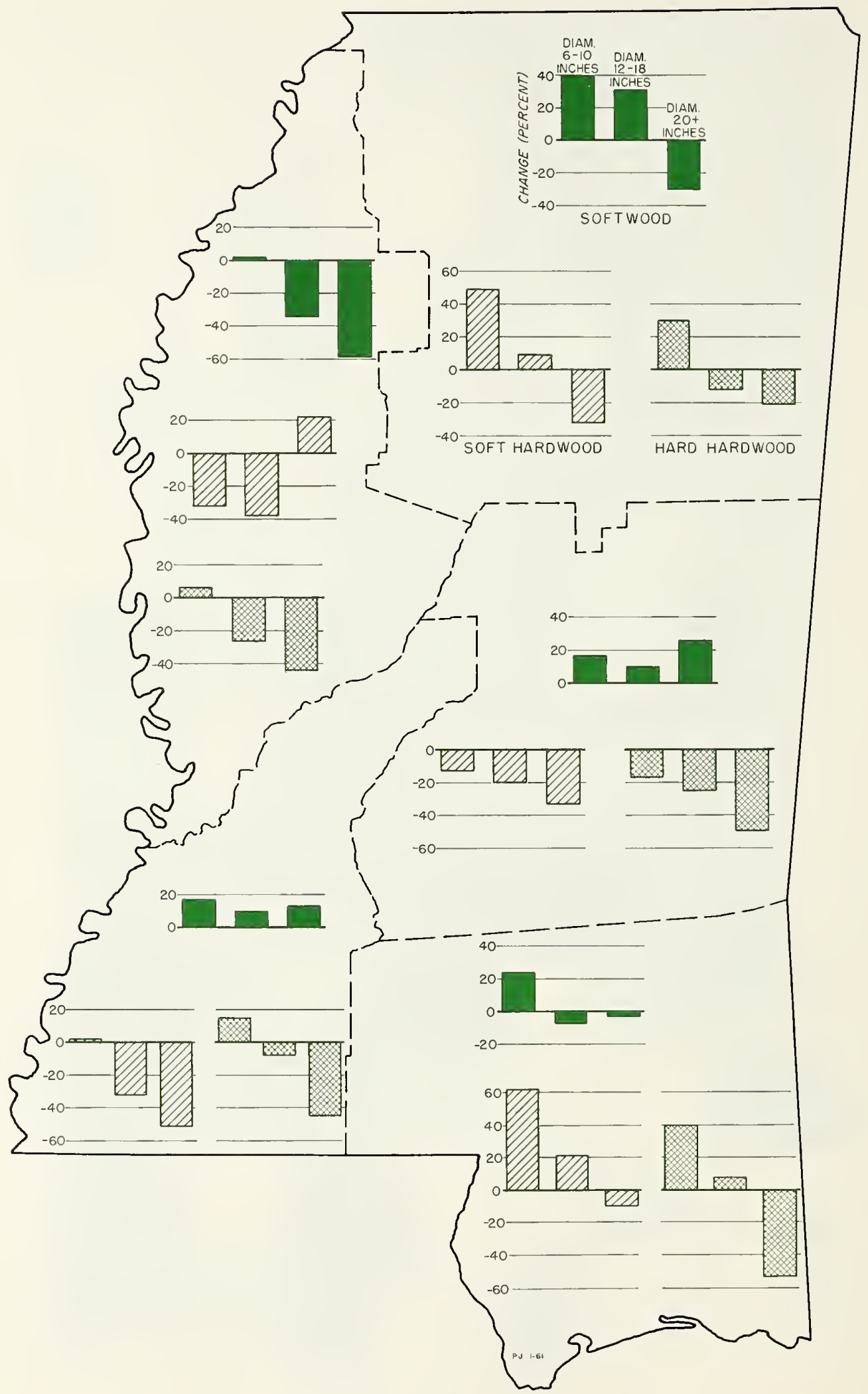

Figure 5. Change in number of growing stock trees between surveys (1948-57), by survey region, species group, and tree diameter class. 


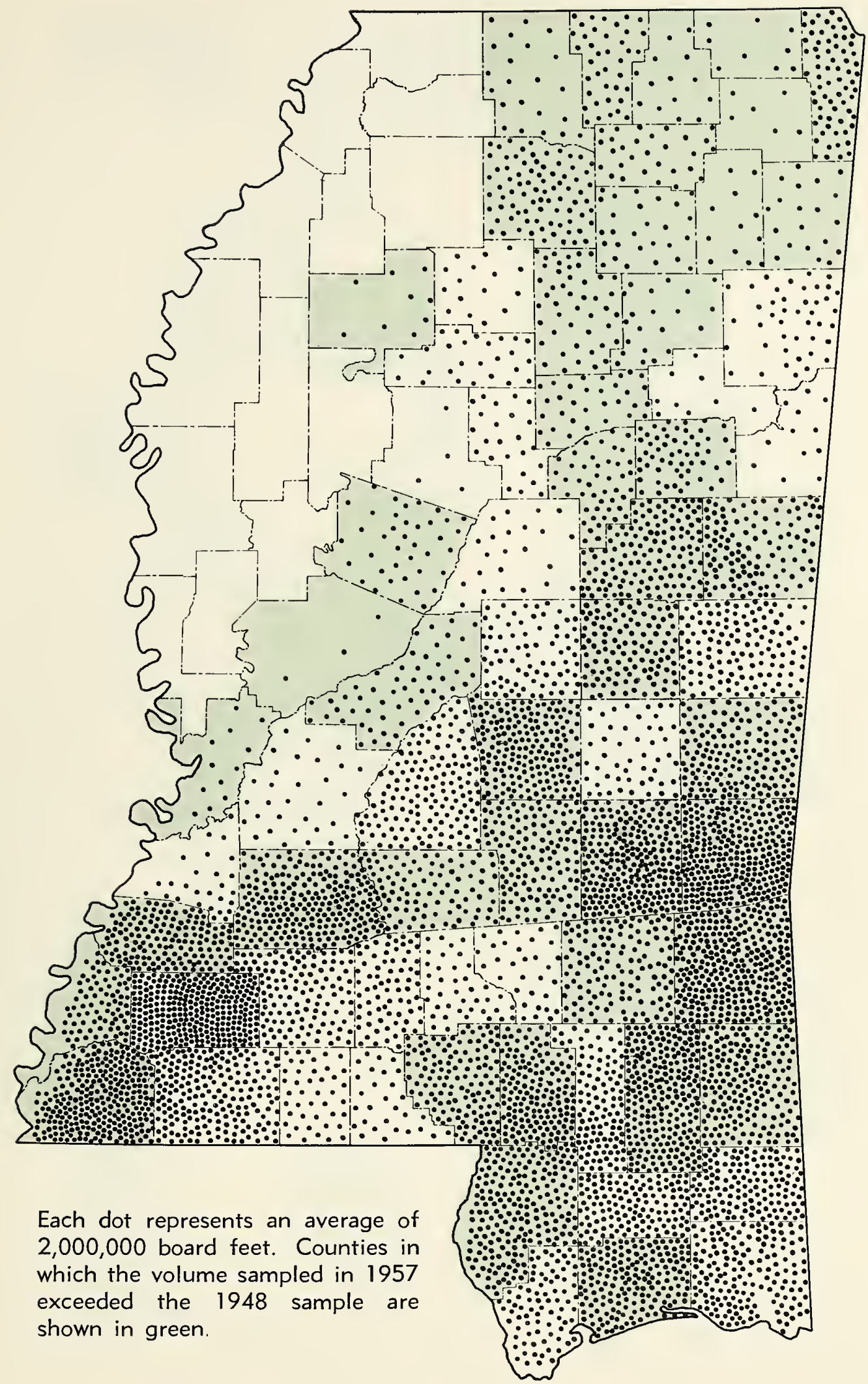

Figure 6. Pine sawtimber volume. 


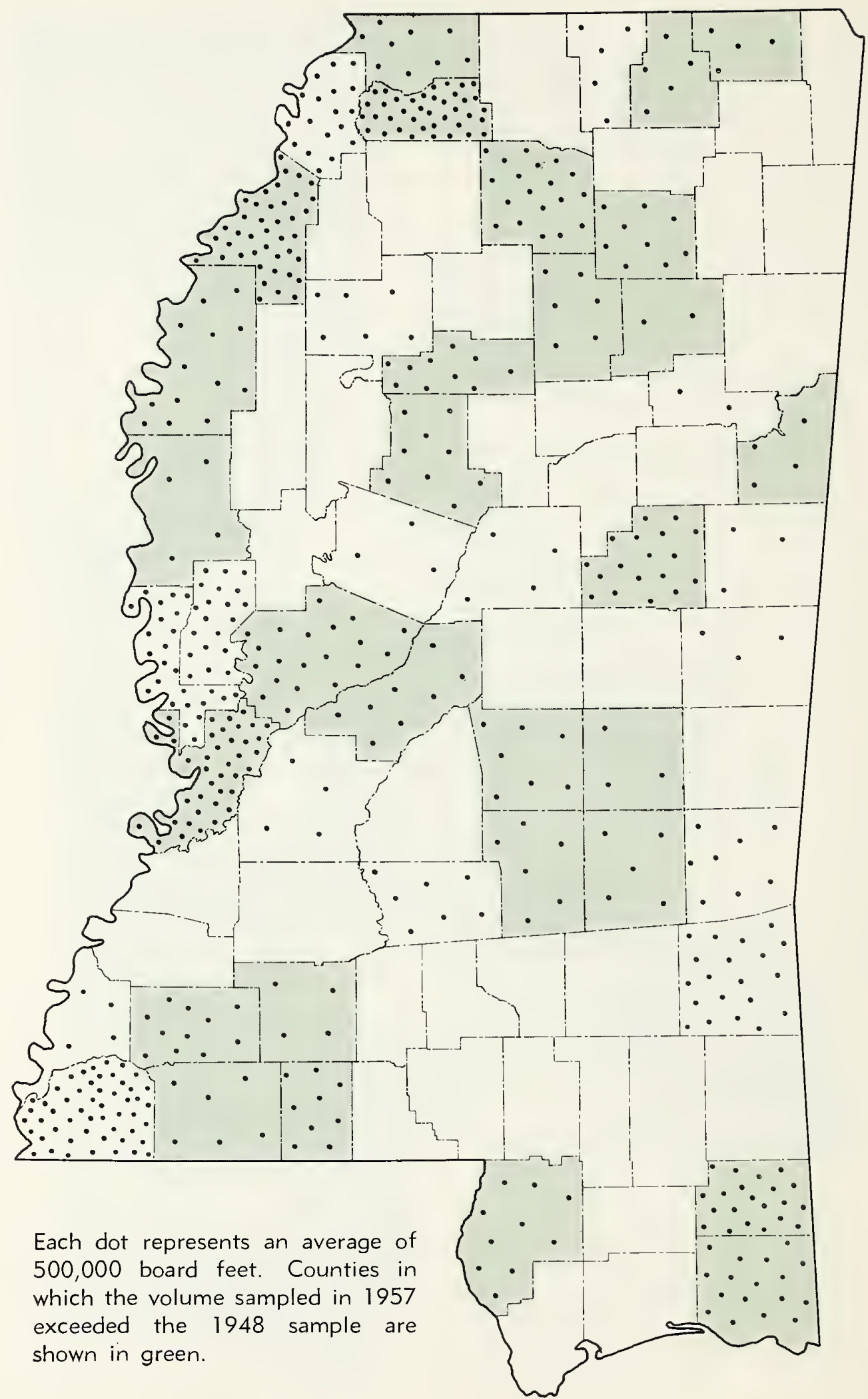

Figure 7. Ash sawtimber volume. 


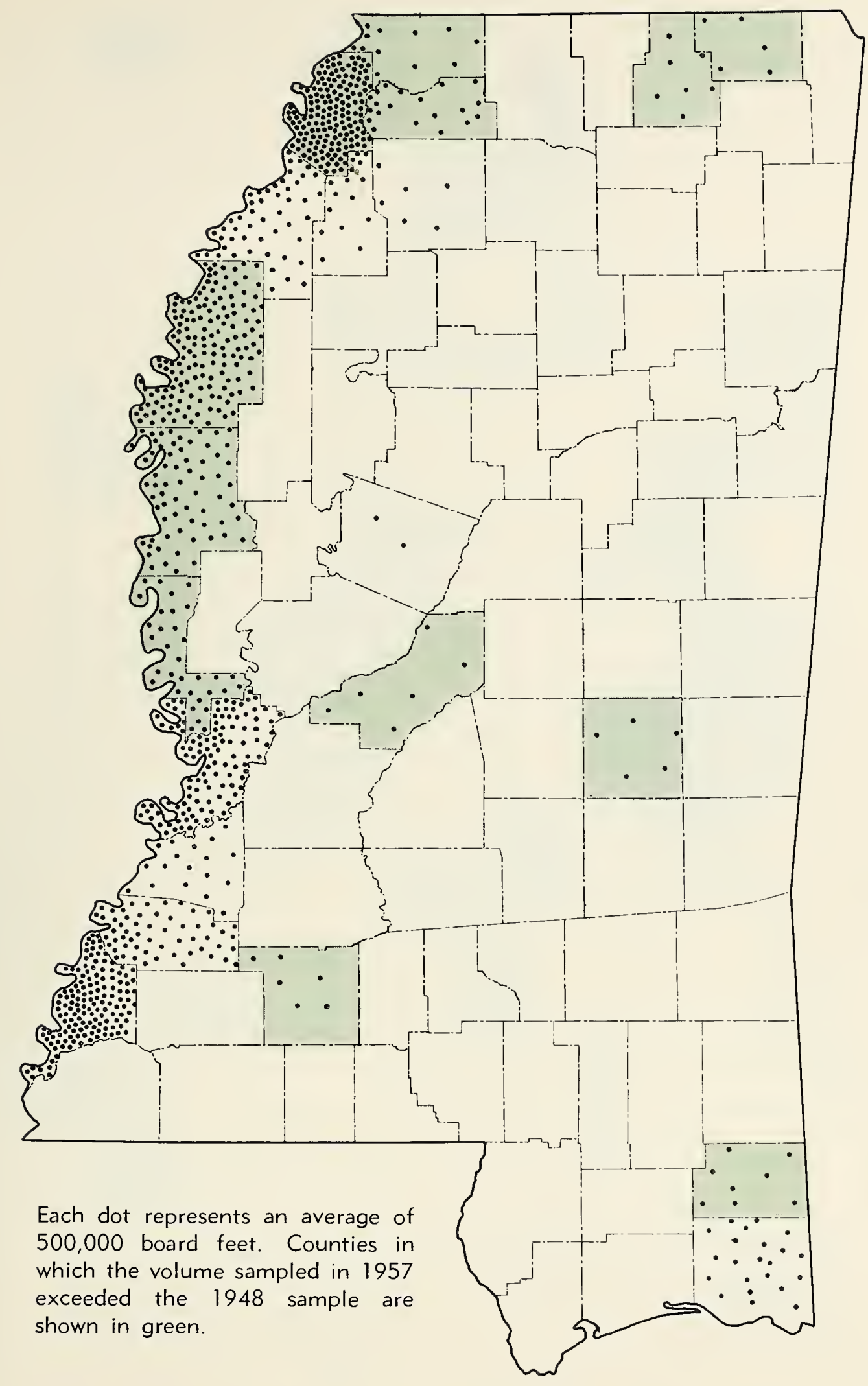

Figure 8. Cottonwood sawtimber volume. 


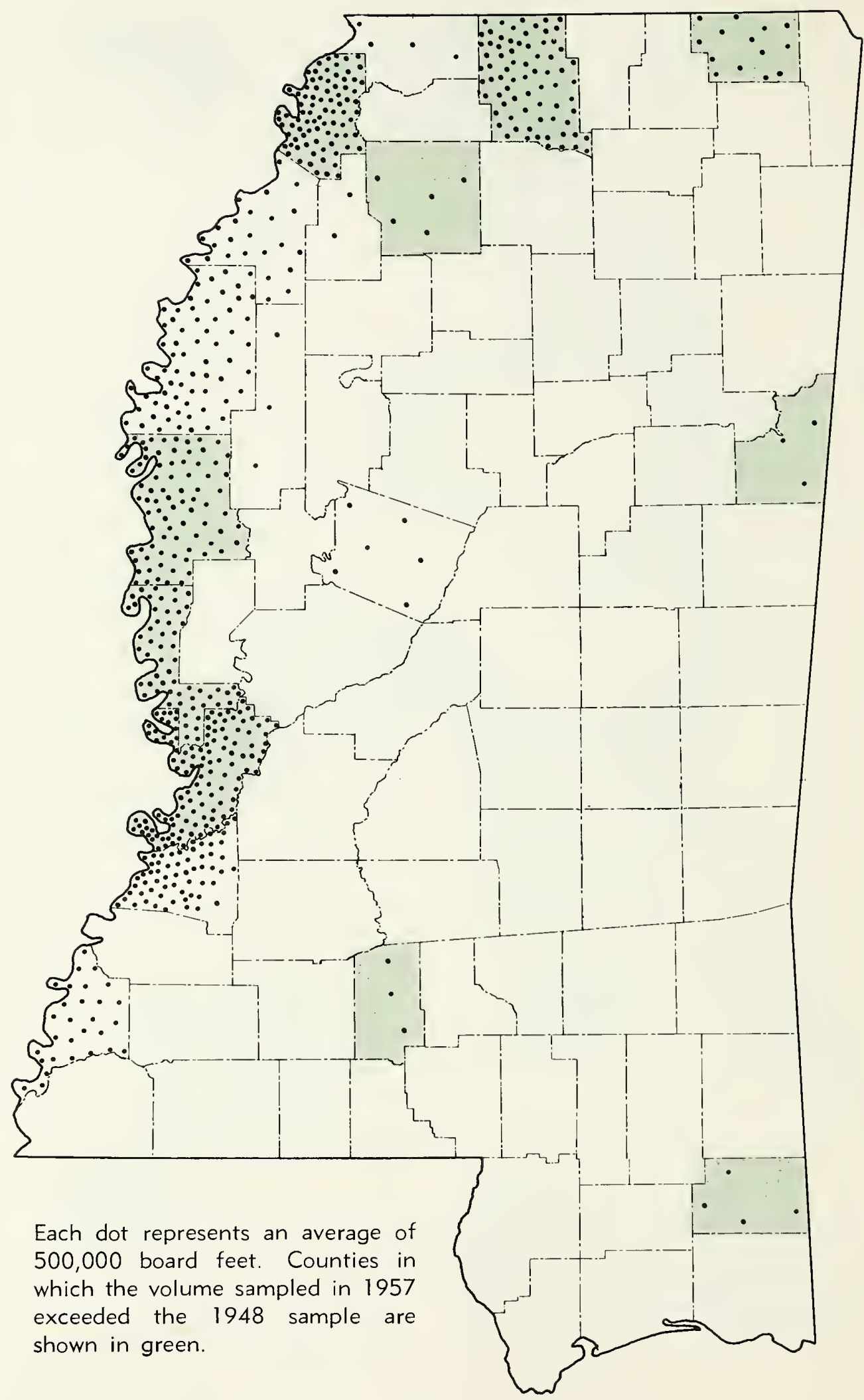

Figure 9. Willow sawtimber volume. 


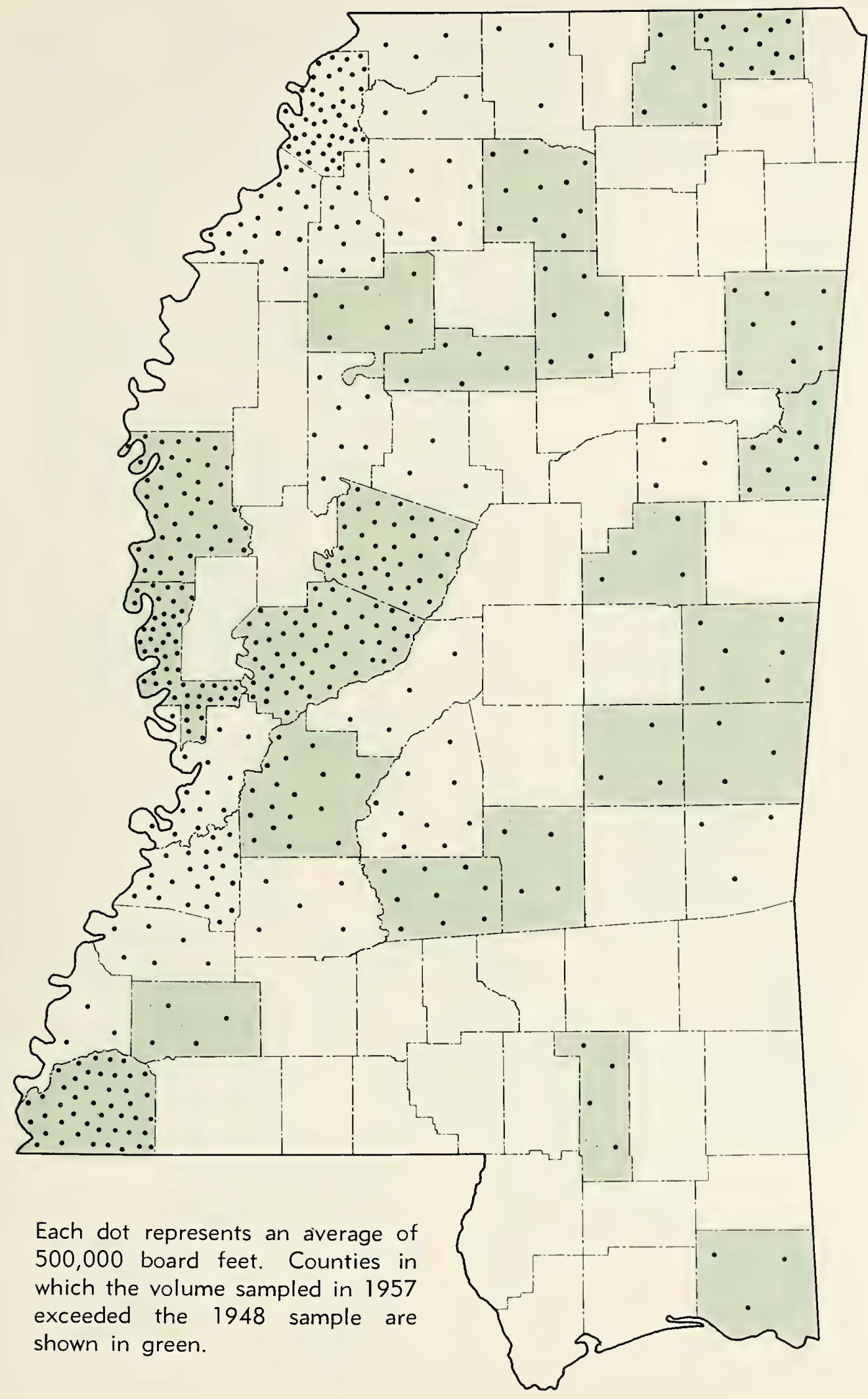

Figure 10. White elm sawtimber volume. 


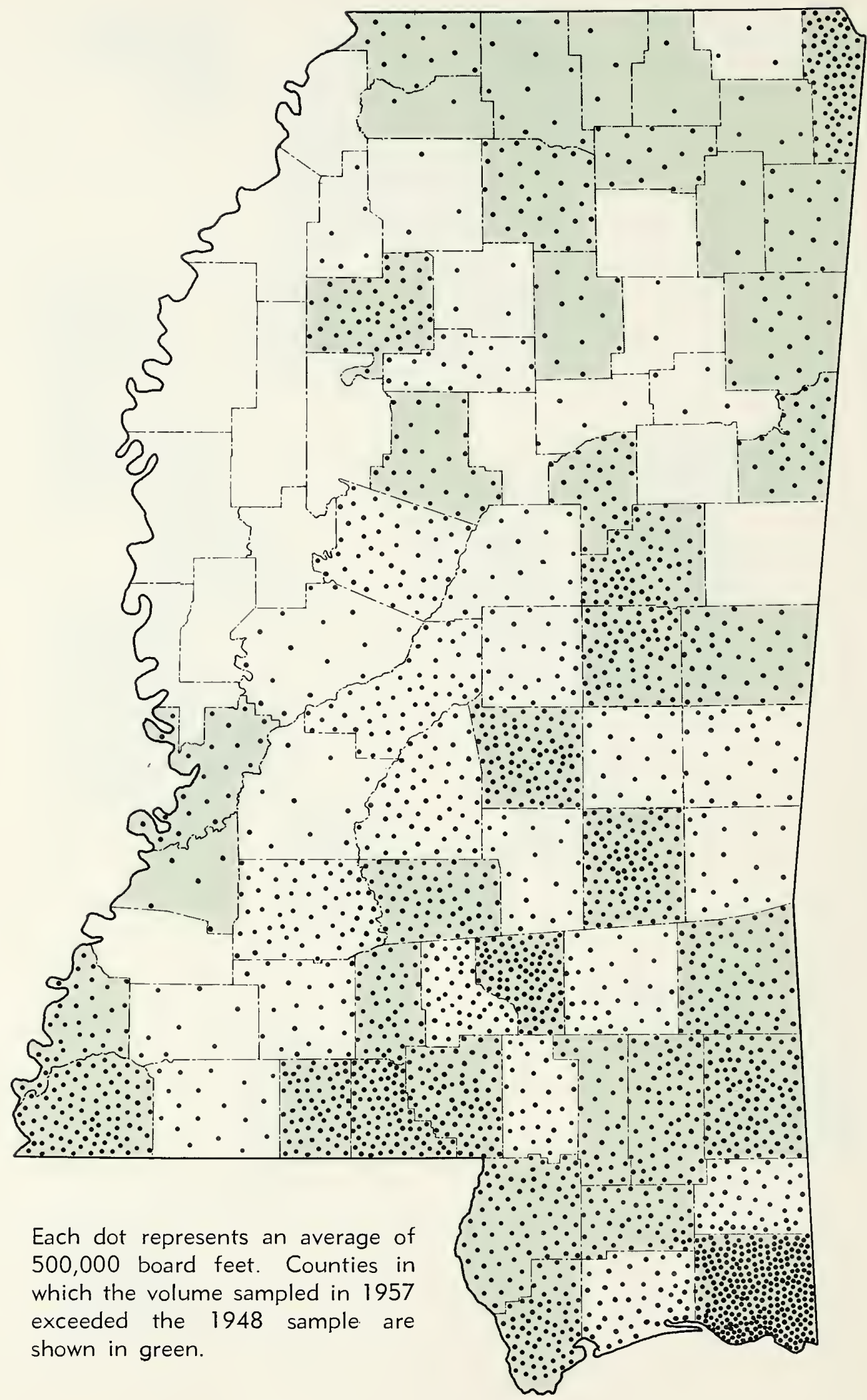

Figure 11. Tupelo and blackgum sawtimber volume. 


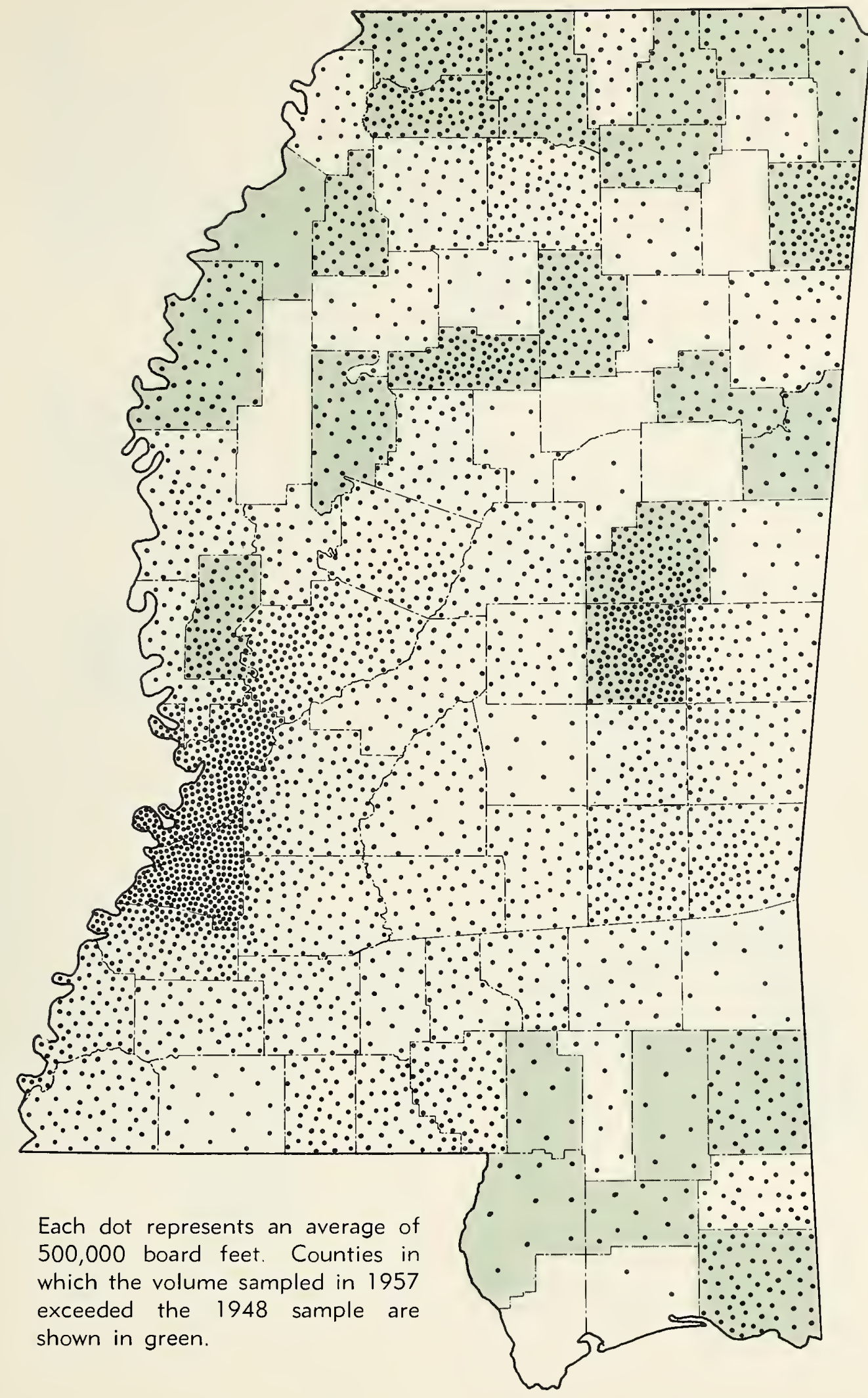

Figure 12. Sweetgum sawtimber volume. 


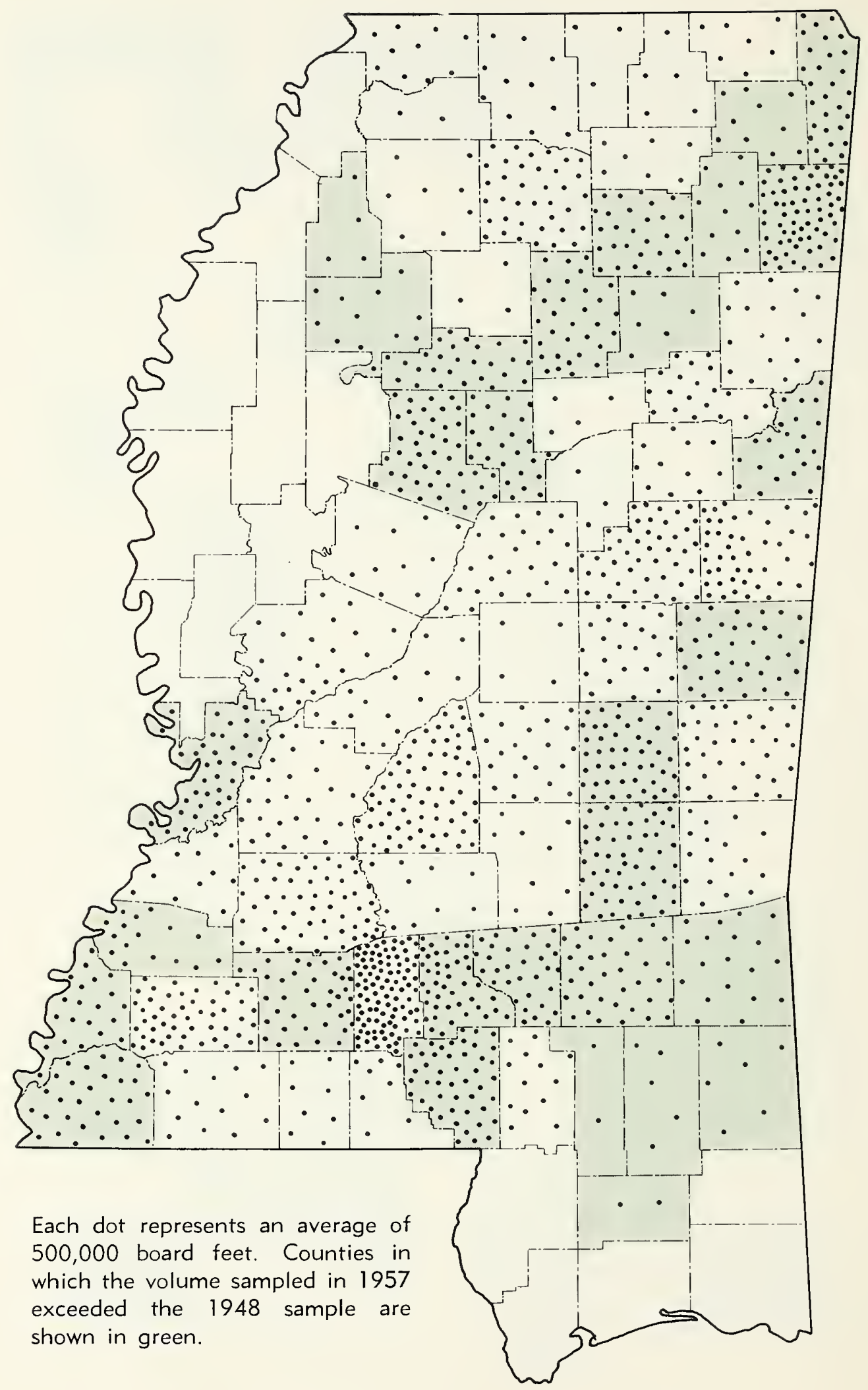

Figure 13. Hickory sawtimber volume. 


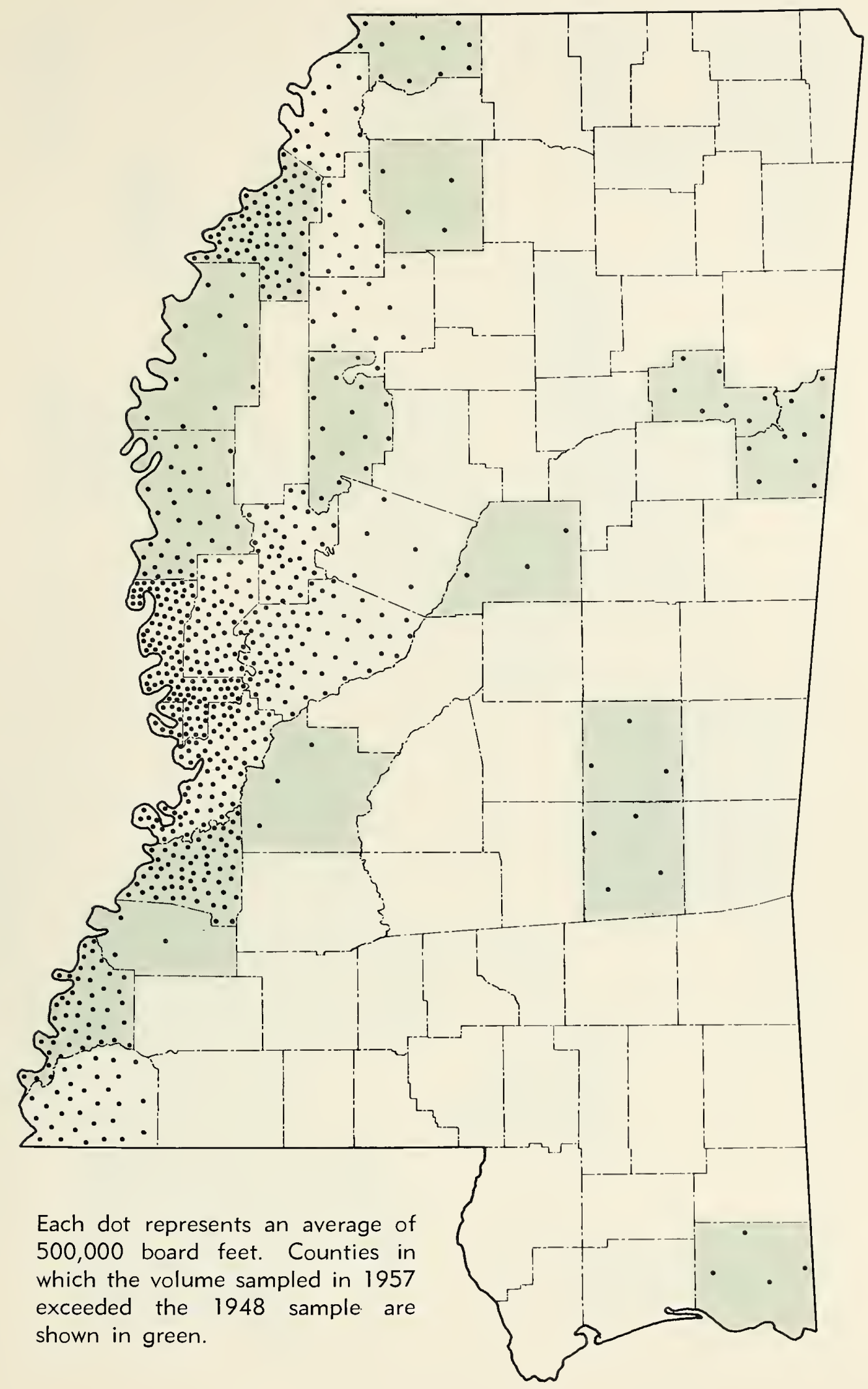

Figure 14. Pecan sawtimber volume. 


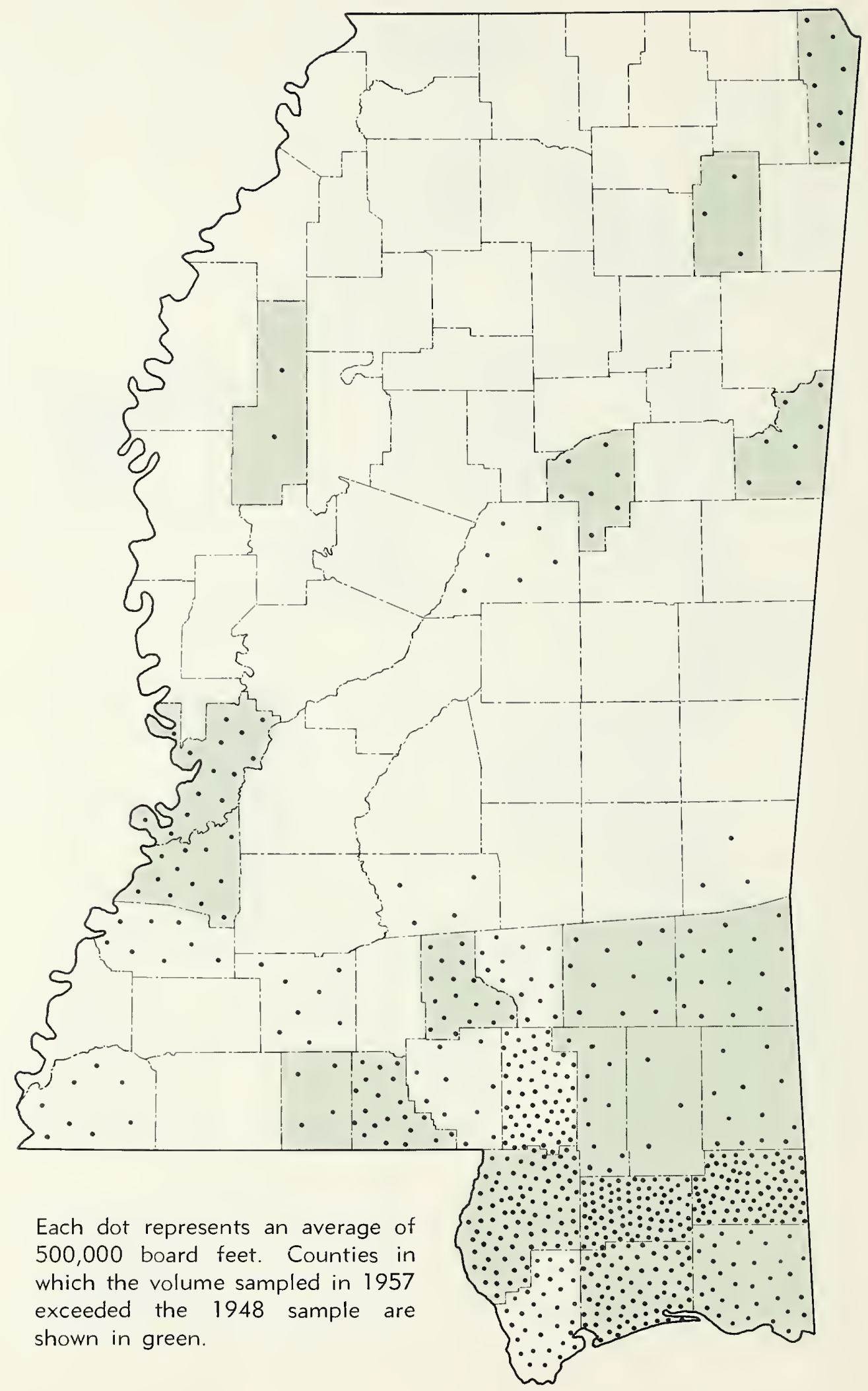

Figure 15. Sweetbay and magnolia sawtimber volume. 


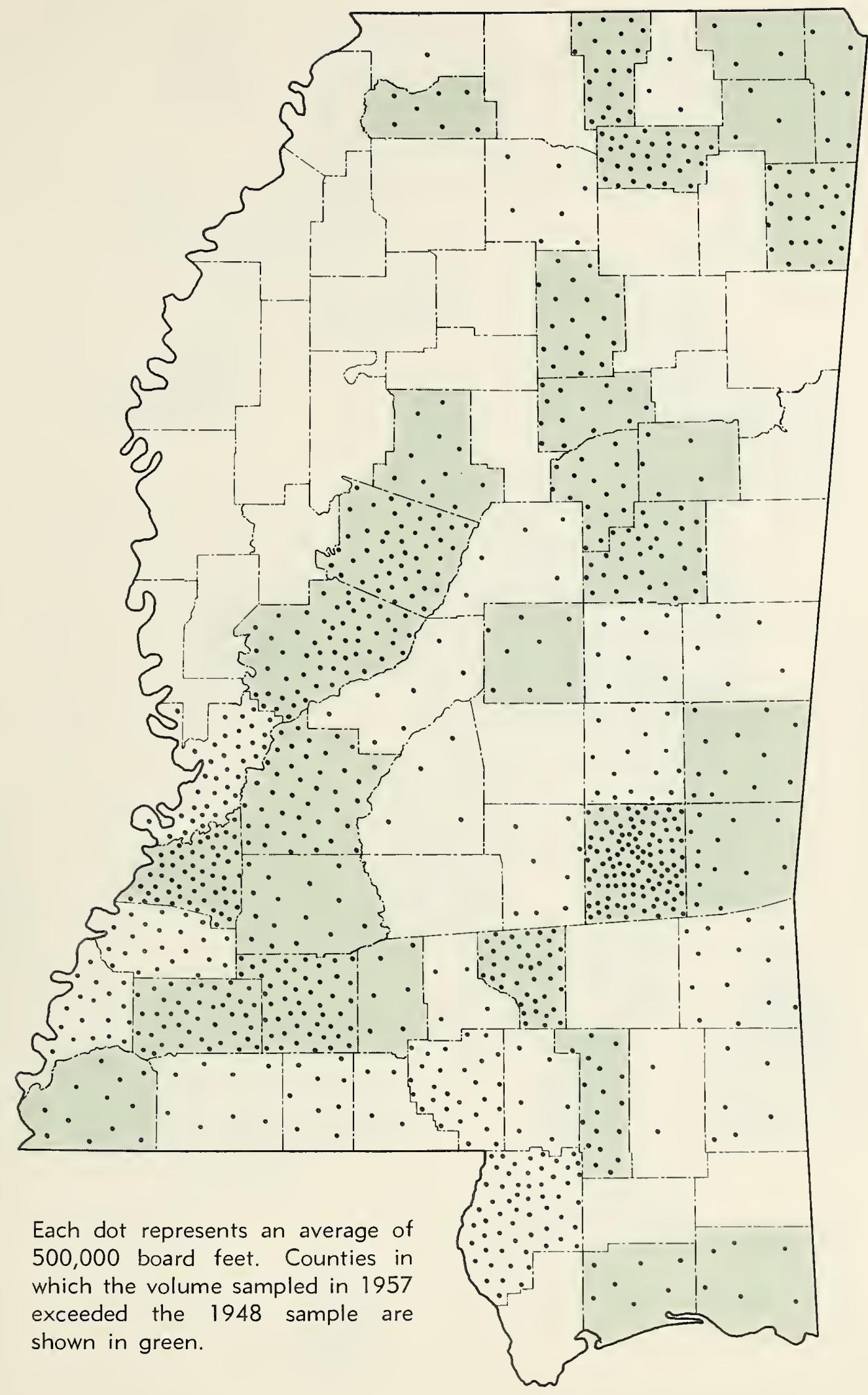

Figure 16. Yellow-poplar sawtimber volume. 


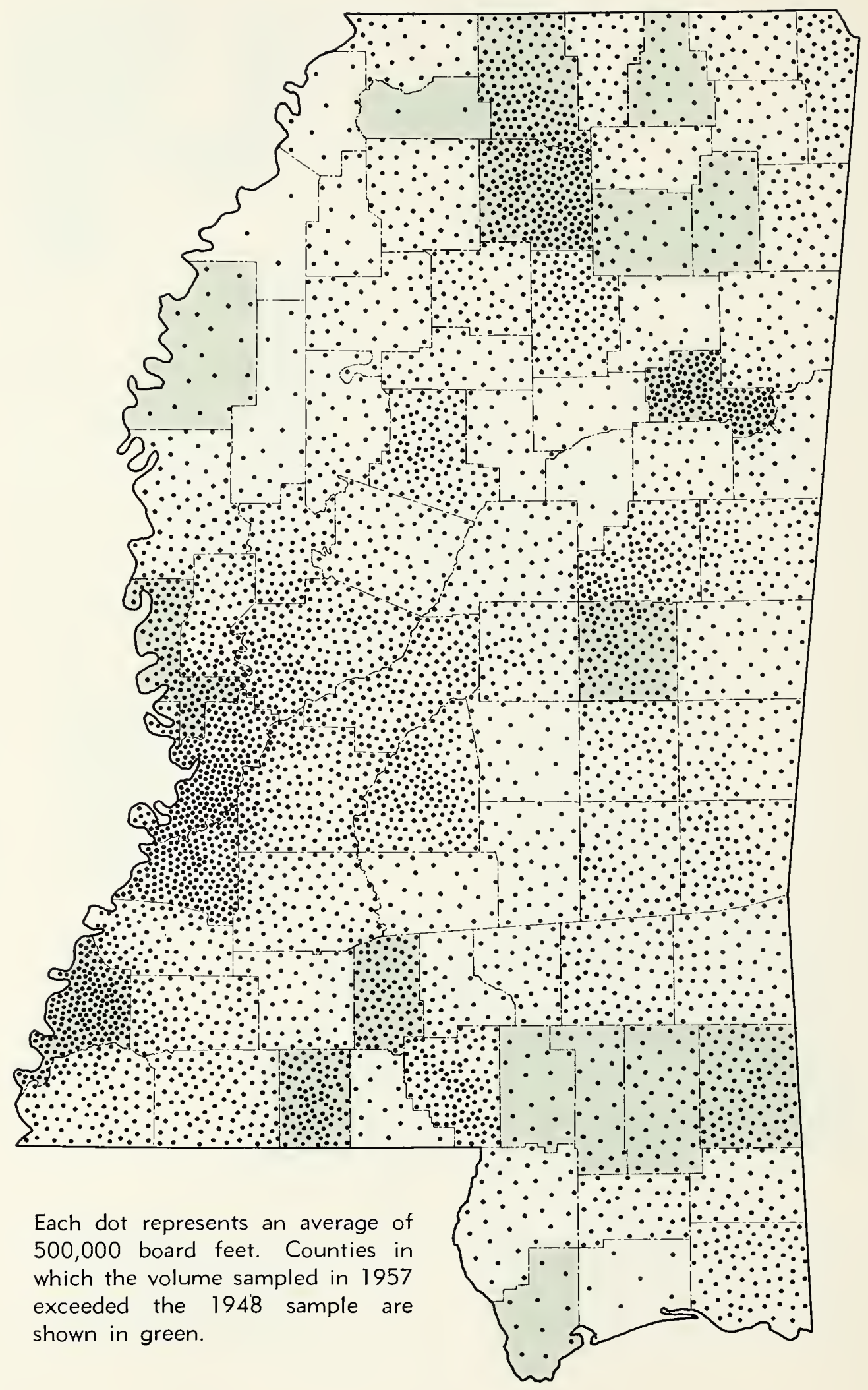

Figure 17. Red oak sawtimber volume. 


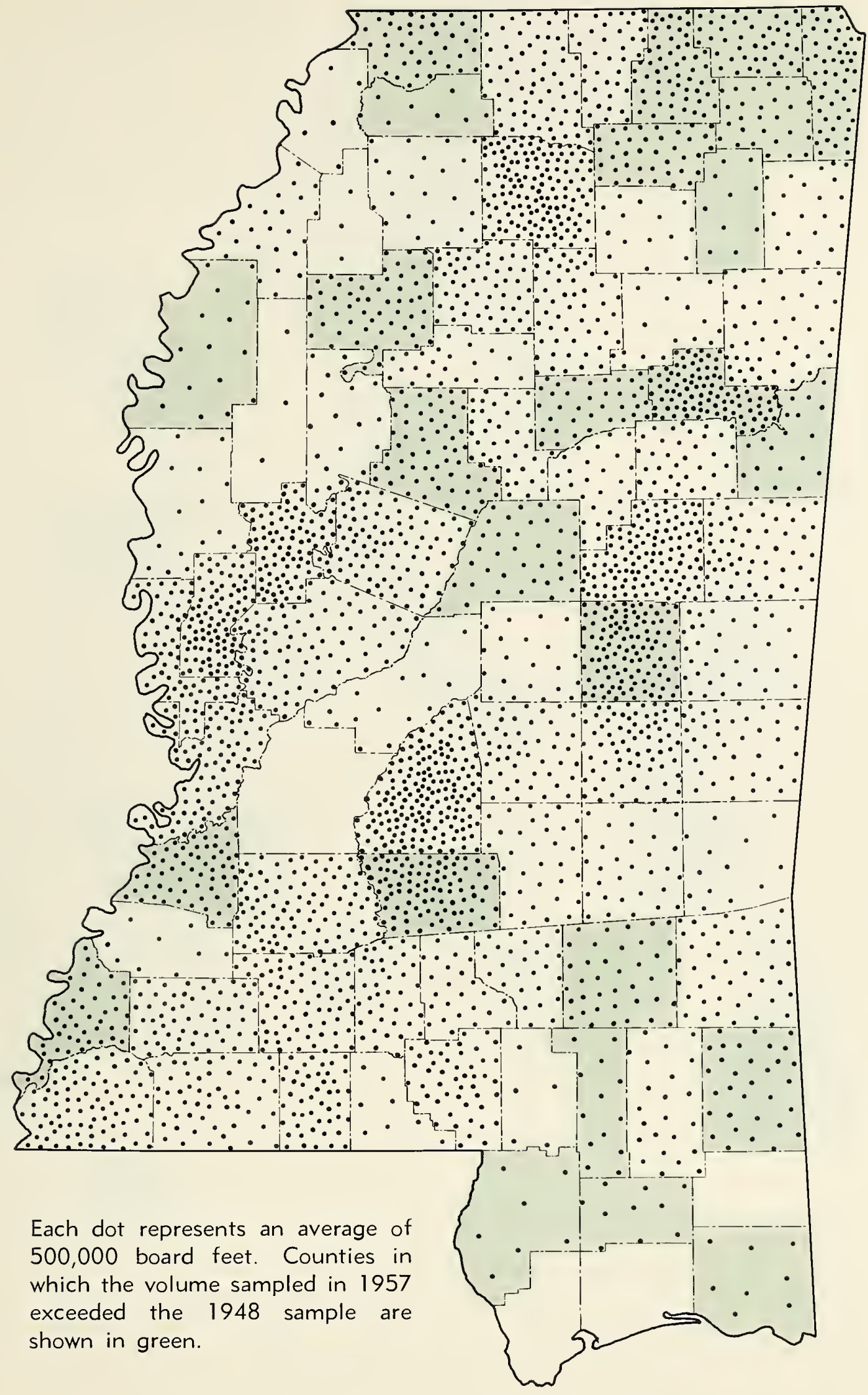

Figure 18. White oak sawtimber volume. 


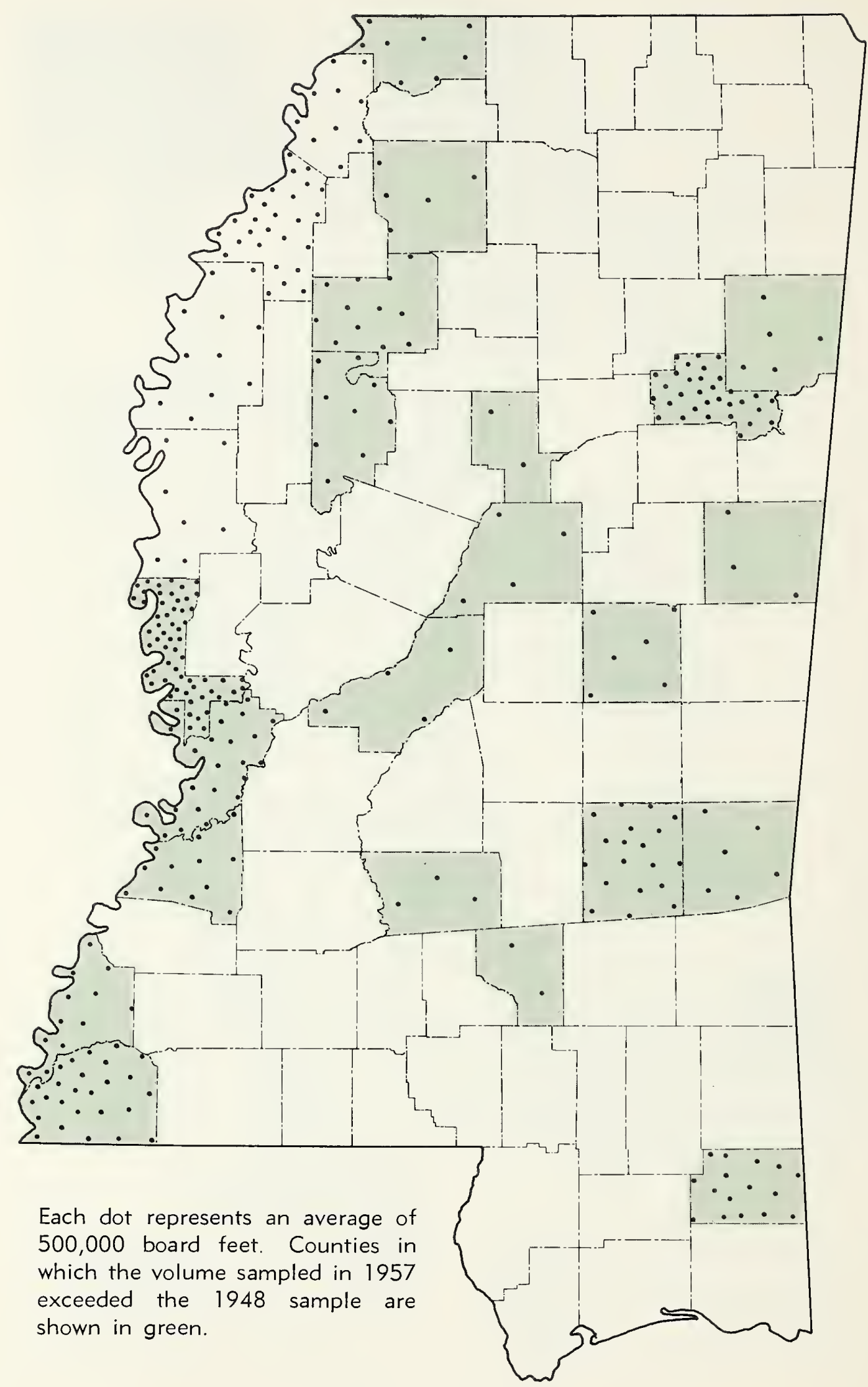

Figure 19. Hackberry sawtimber volume. 


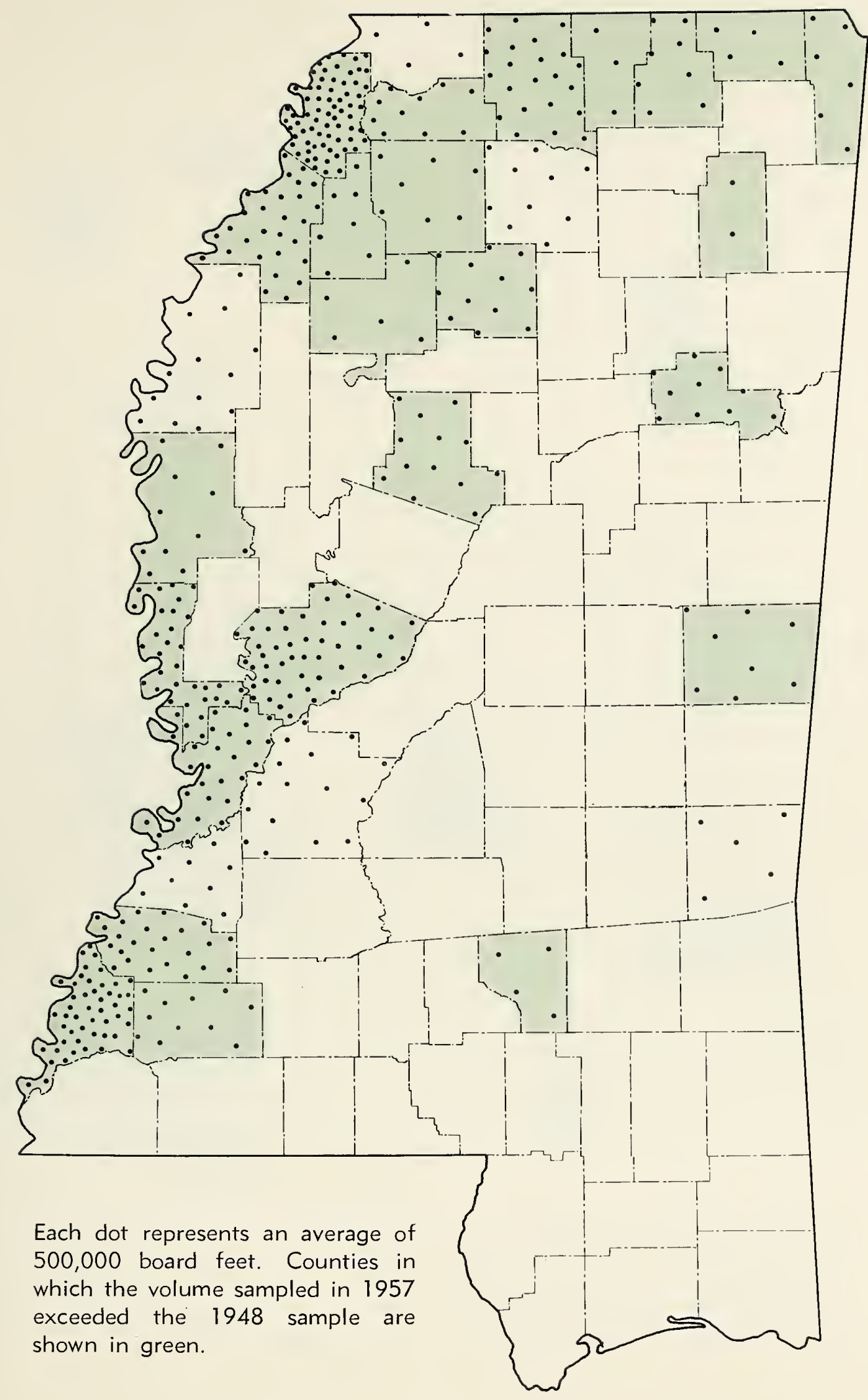

Figure 20. Sycamore sawtimber volume. 


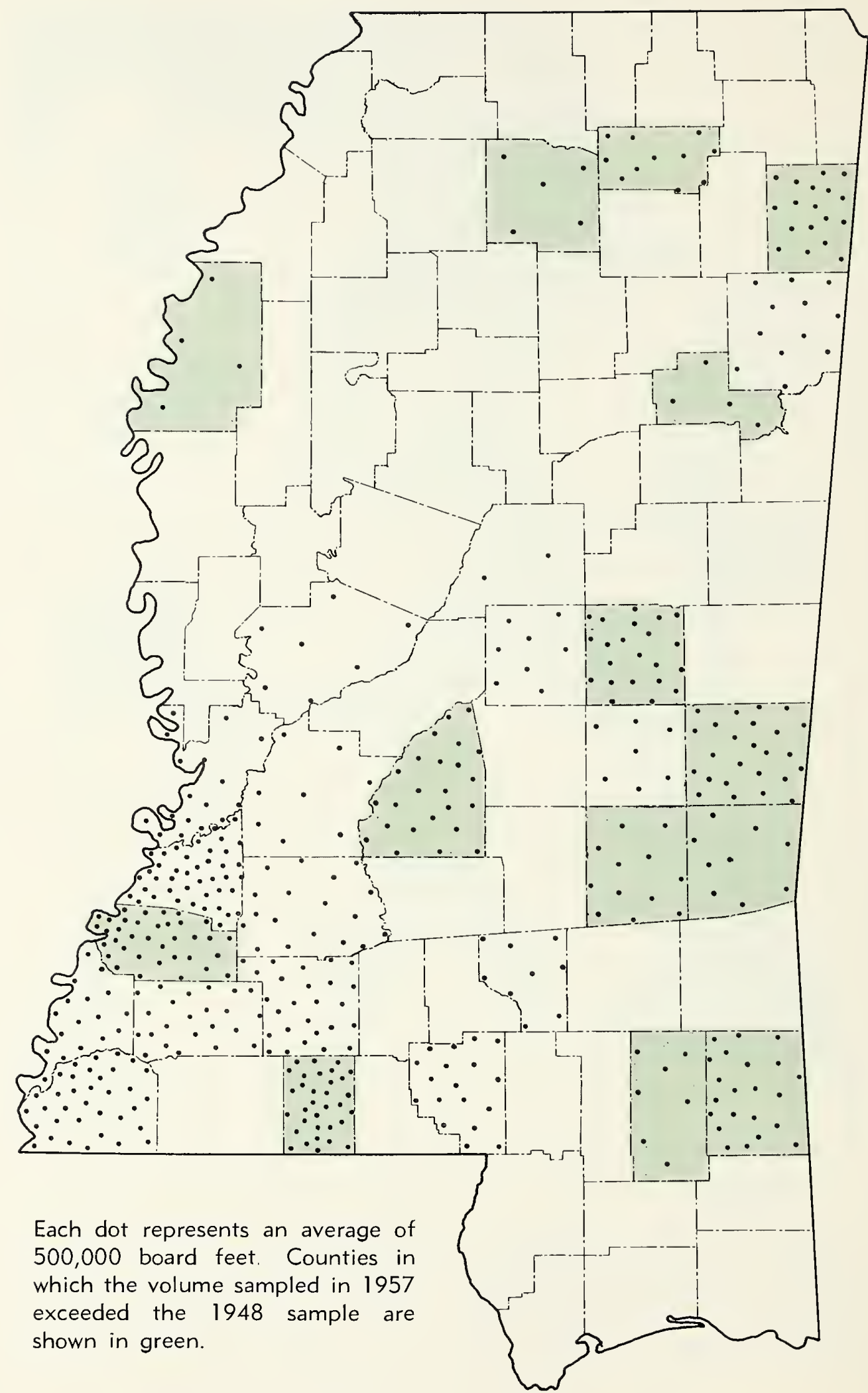

Figure 21. Beech sawtimber volume. 


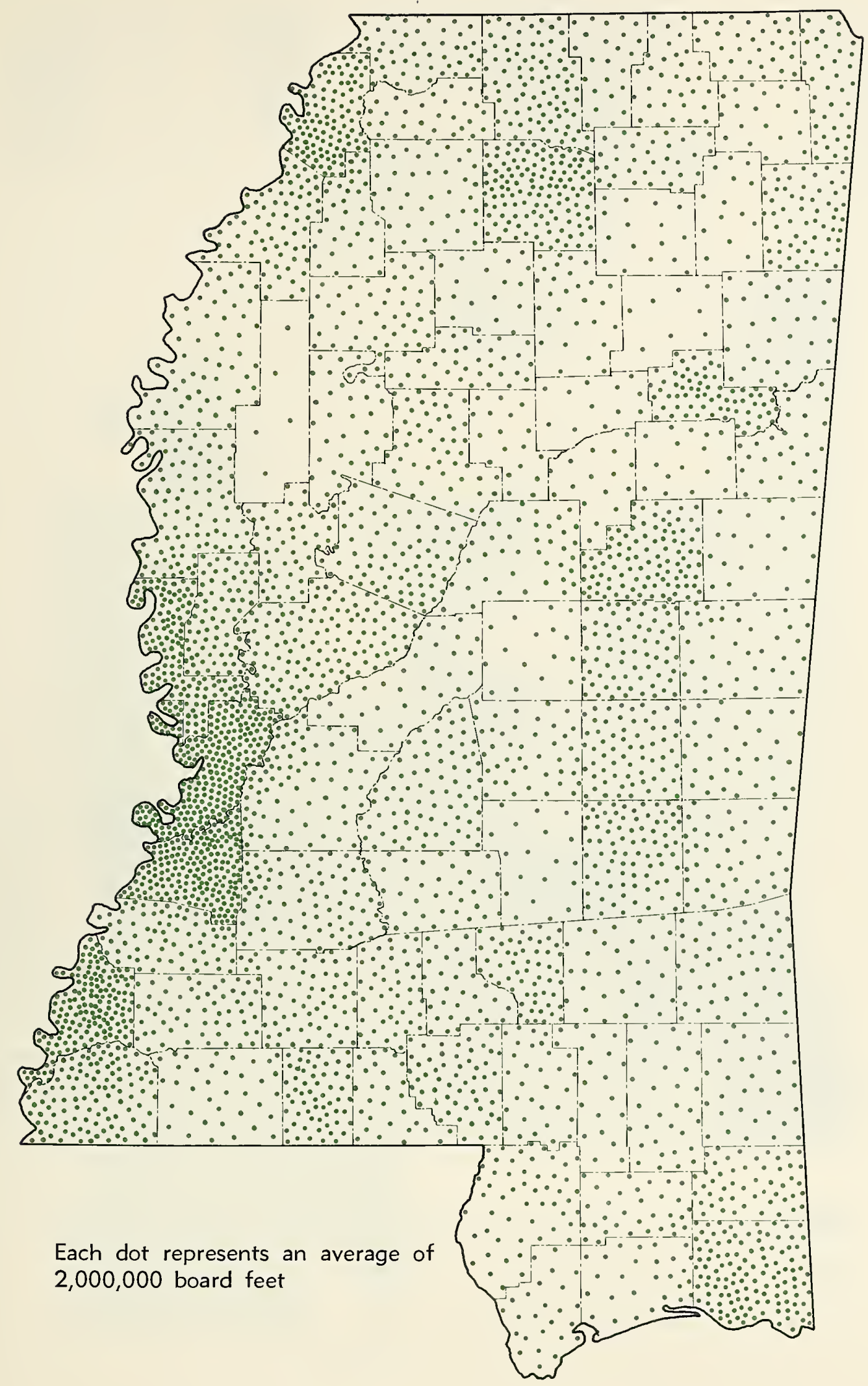

Figure 22. Hardwood sawtimber volume in standard factory lumber logs. 


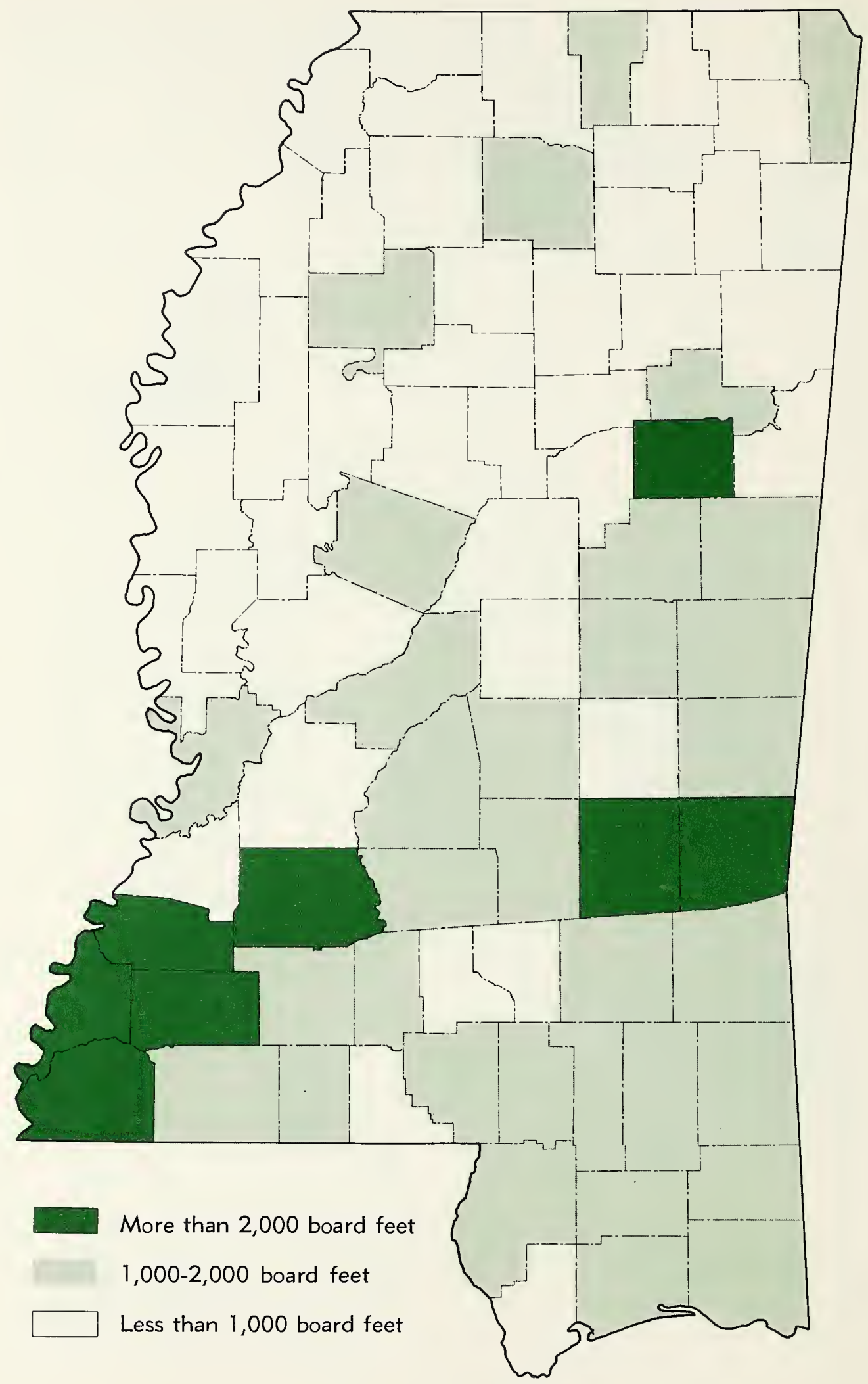

Figure 23. Average volume per acre of softwood sawtimber in softwood types. 


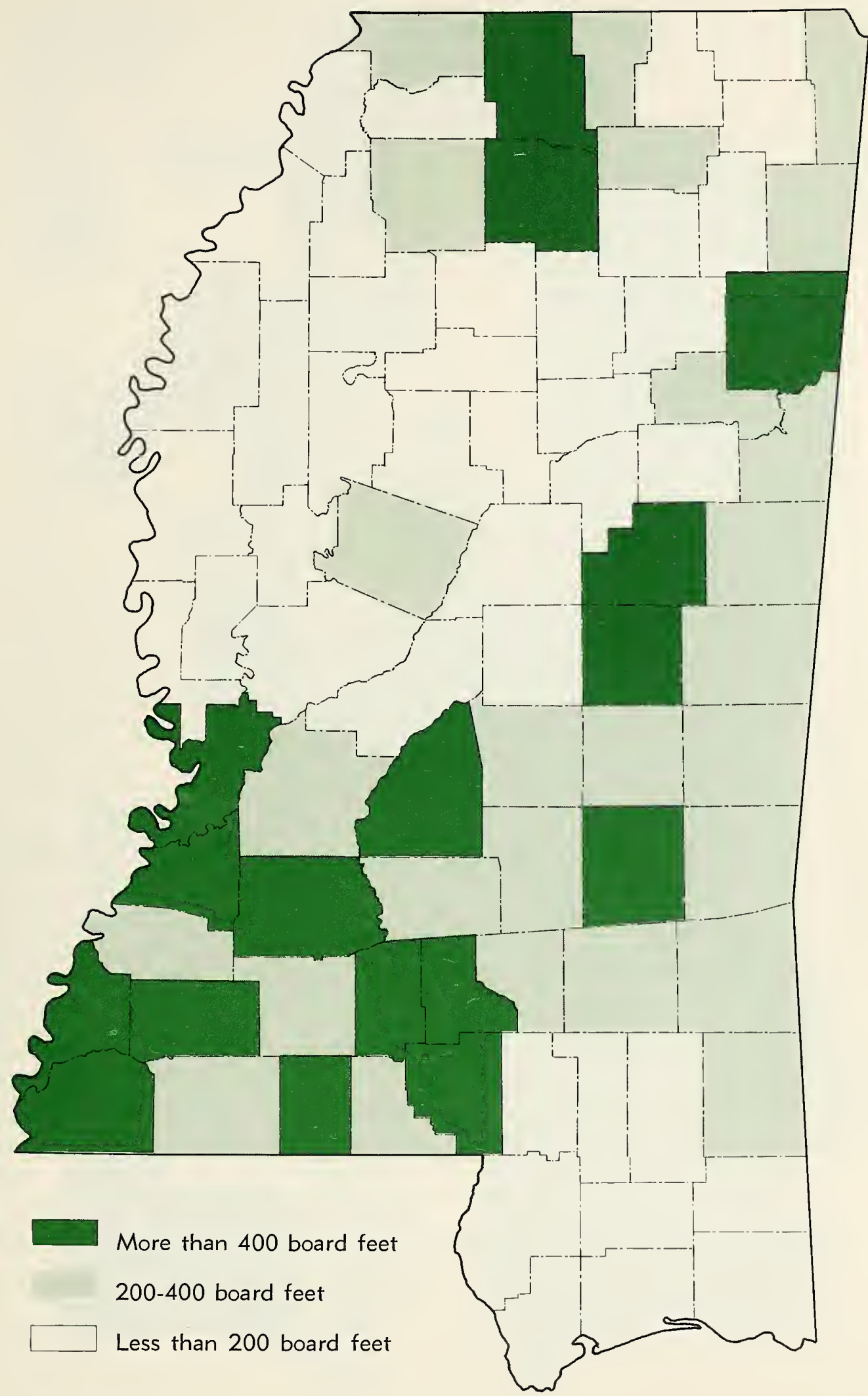

Figure 24. Average volume per acre of hardwood sawtimber in softwood types. 


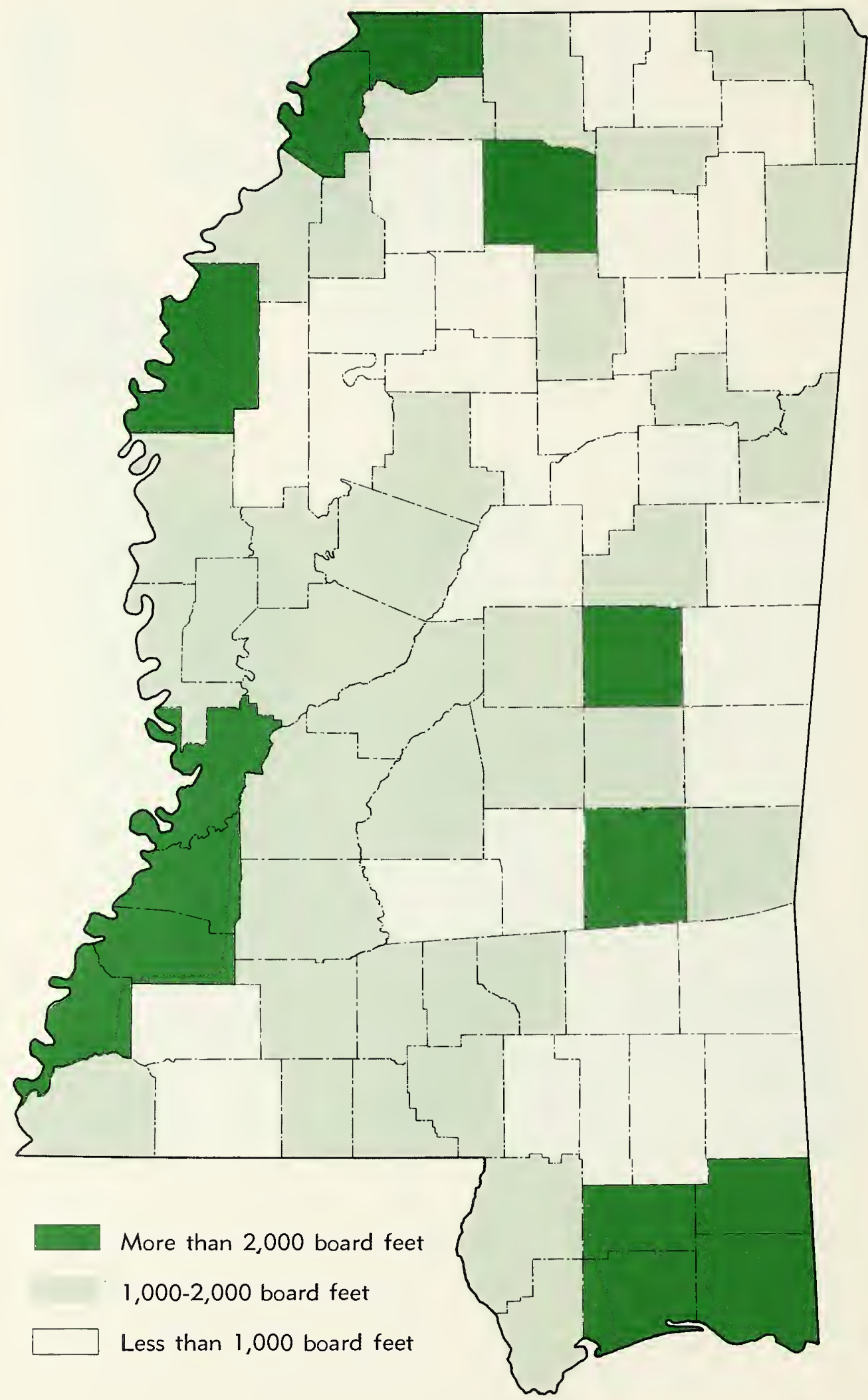

Figure 25. Average sawtimber volume per acre in hardwood types. 


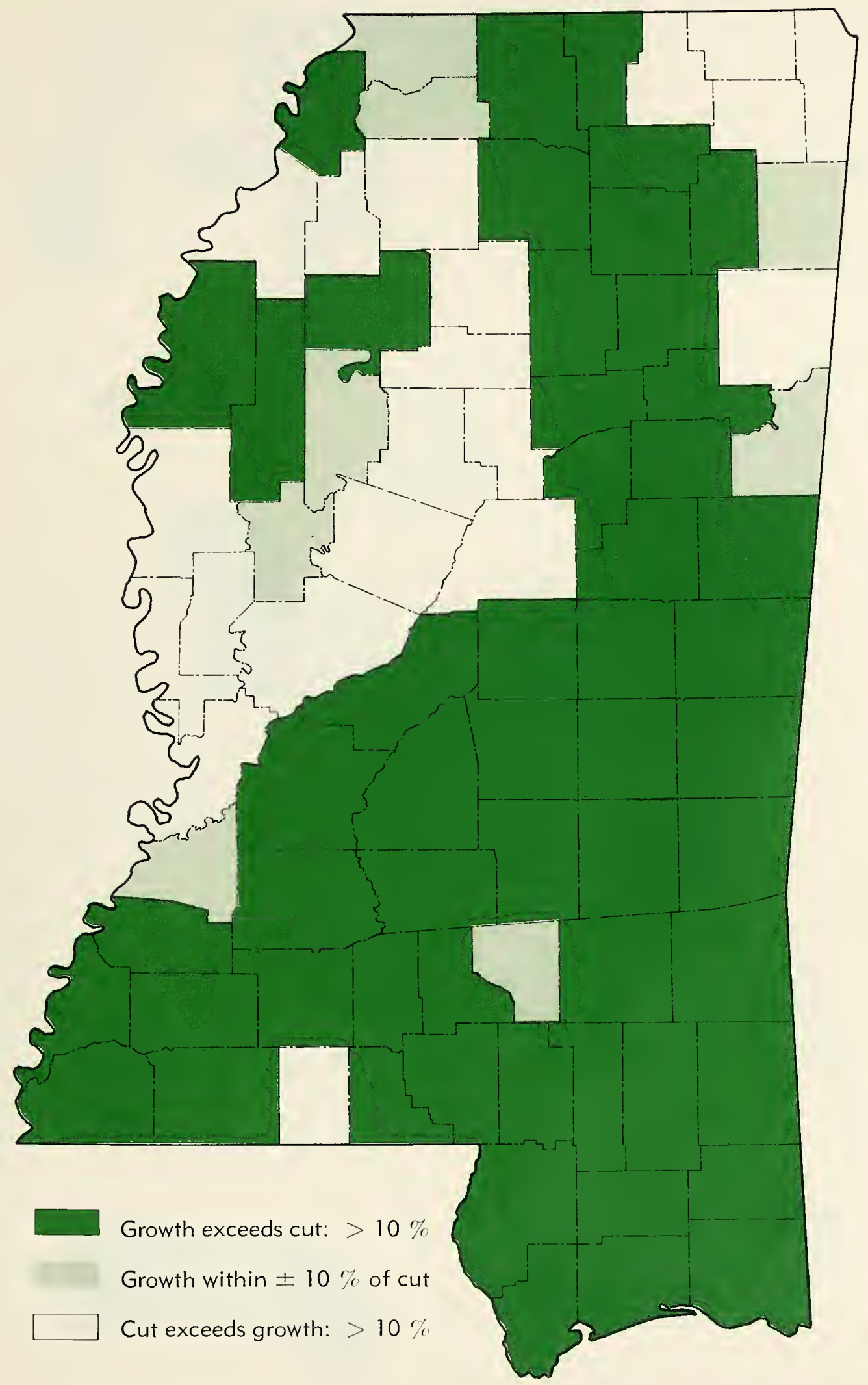

Figure 26. Relationship of growth and cut of softwood sawtimber volume, 1956. 


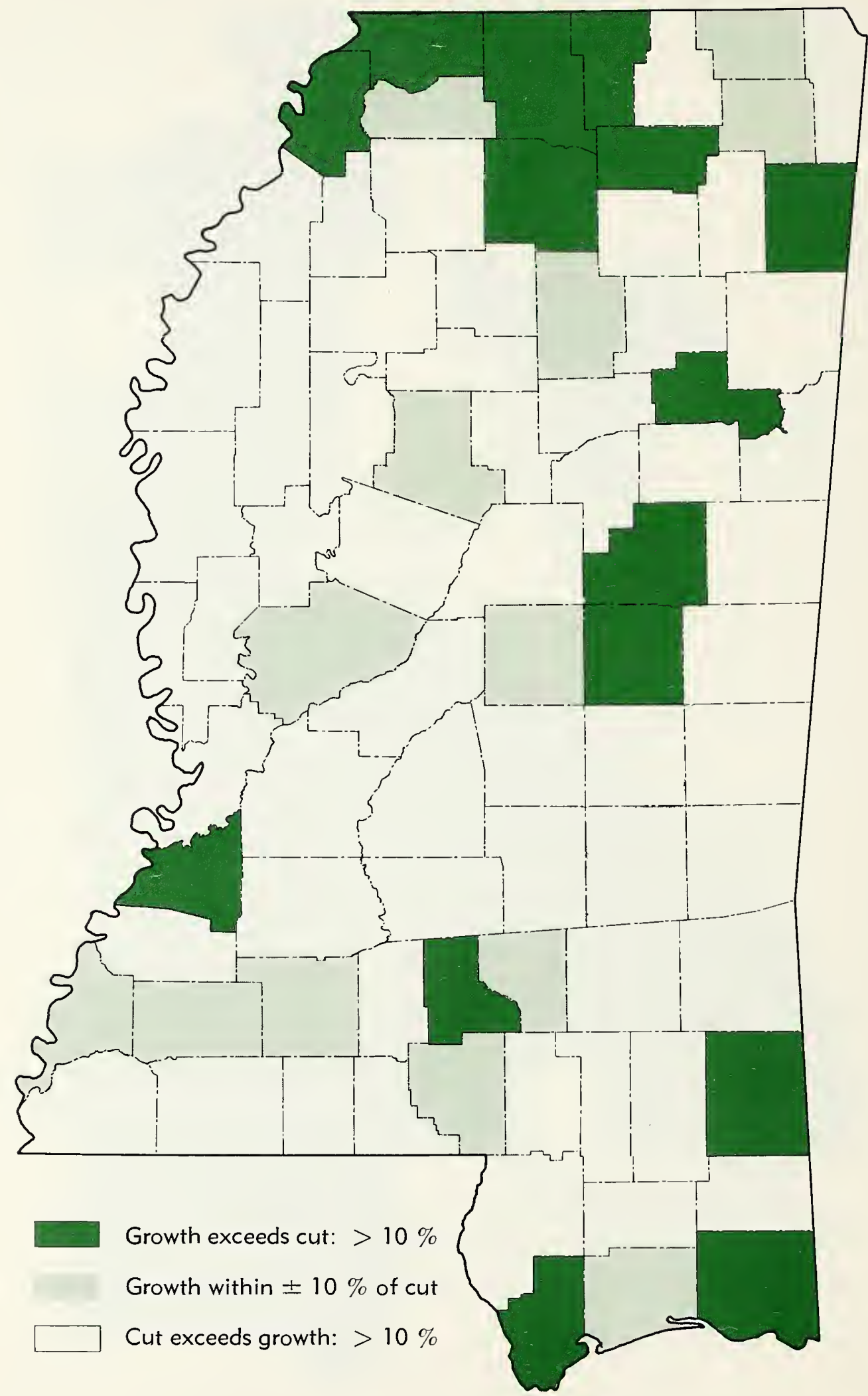

Figure 27. Relationship of growth and cut of hardwood sawtimber volume, 1956. 


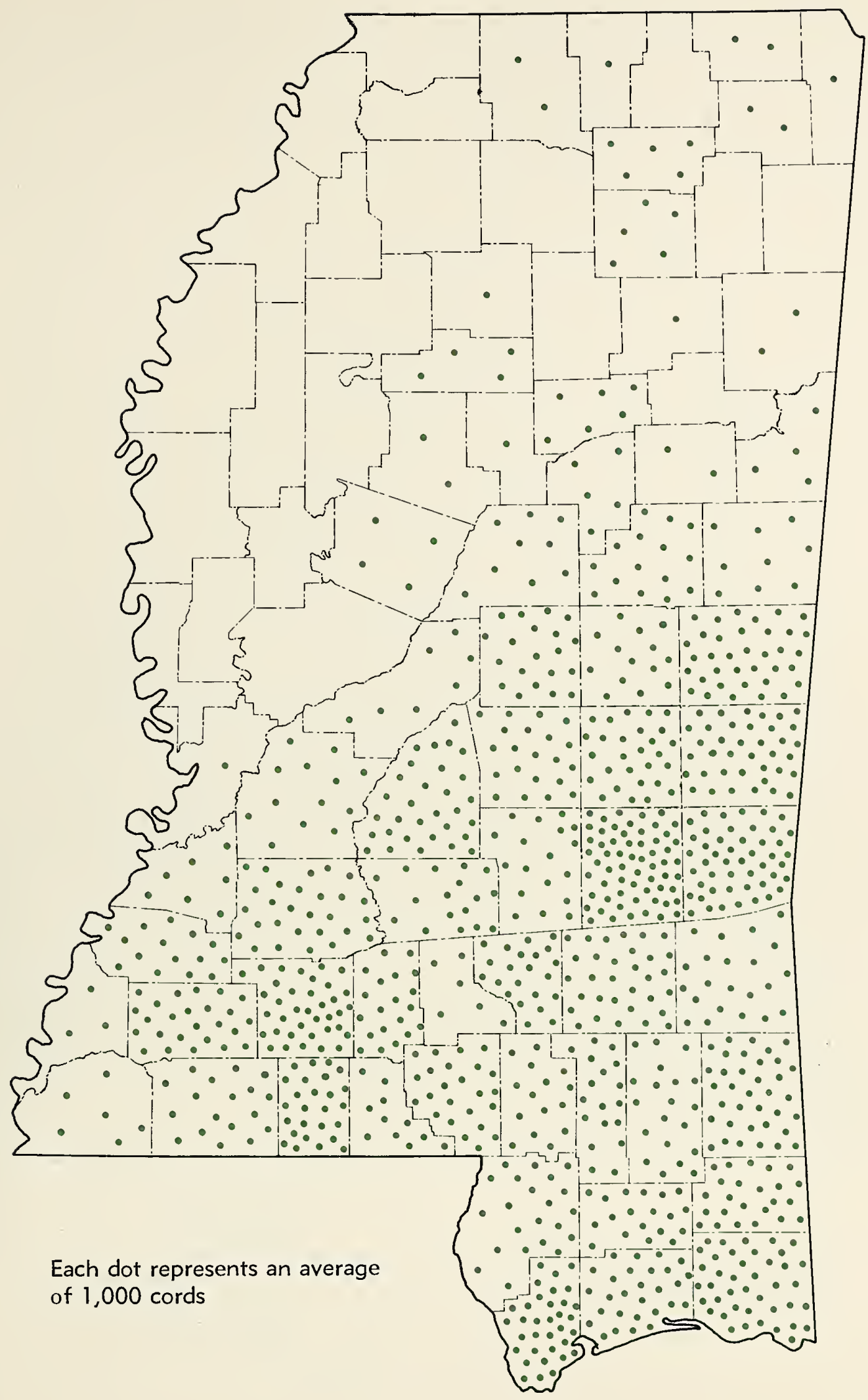

Figure 28. Output of pine pulpwood, 1959. Source: State Tax Commission. 


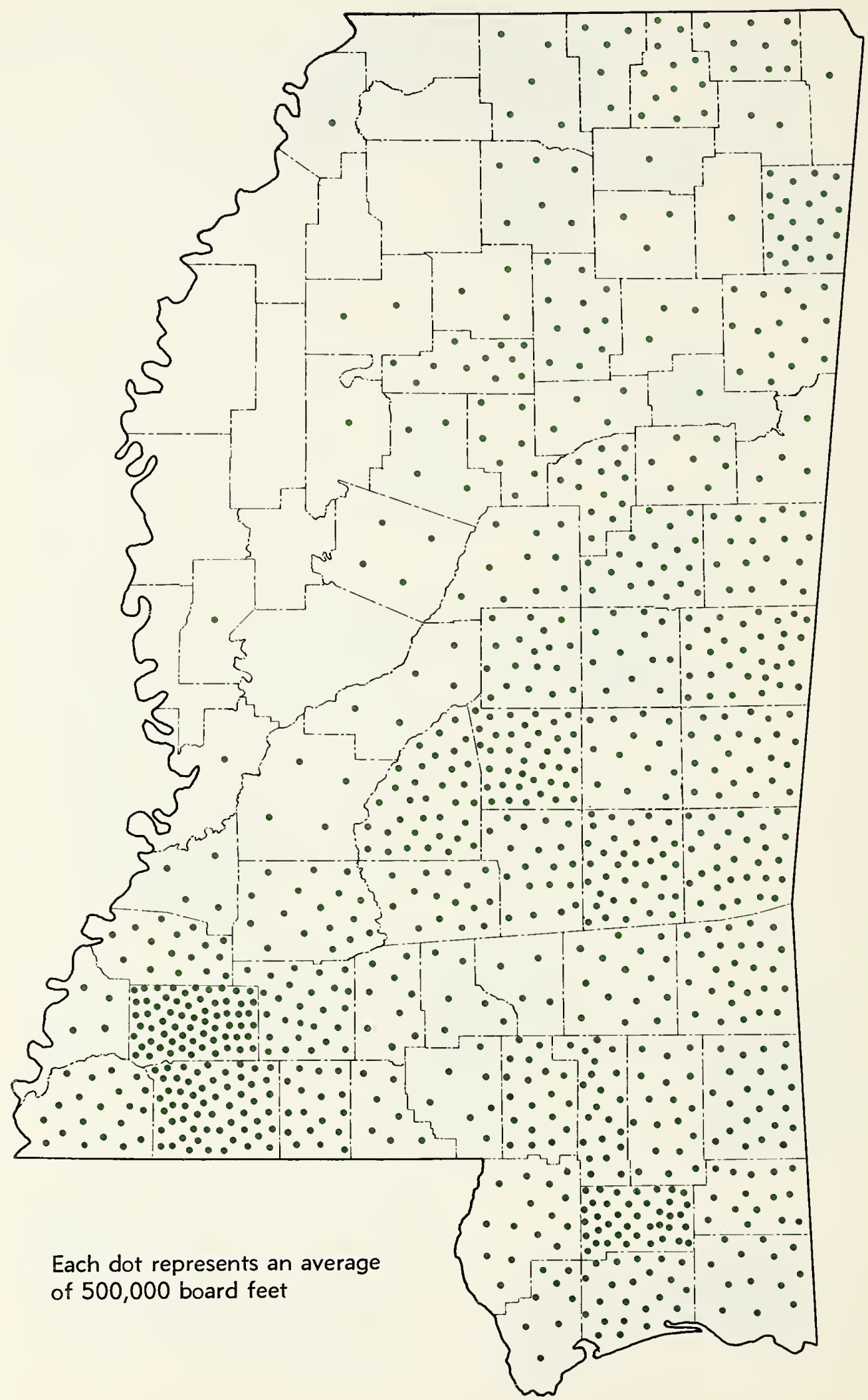

Figure 29. Output of industrial softwood products (except pulpwood), 1959. Source: State Tax Commission. 


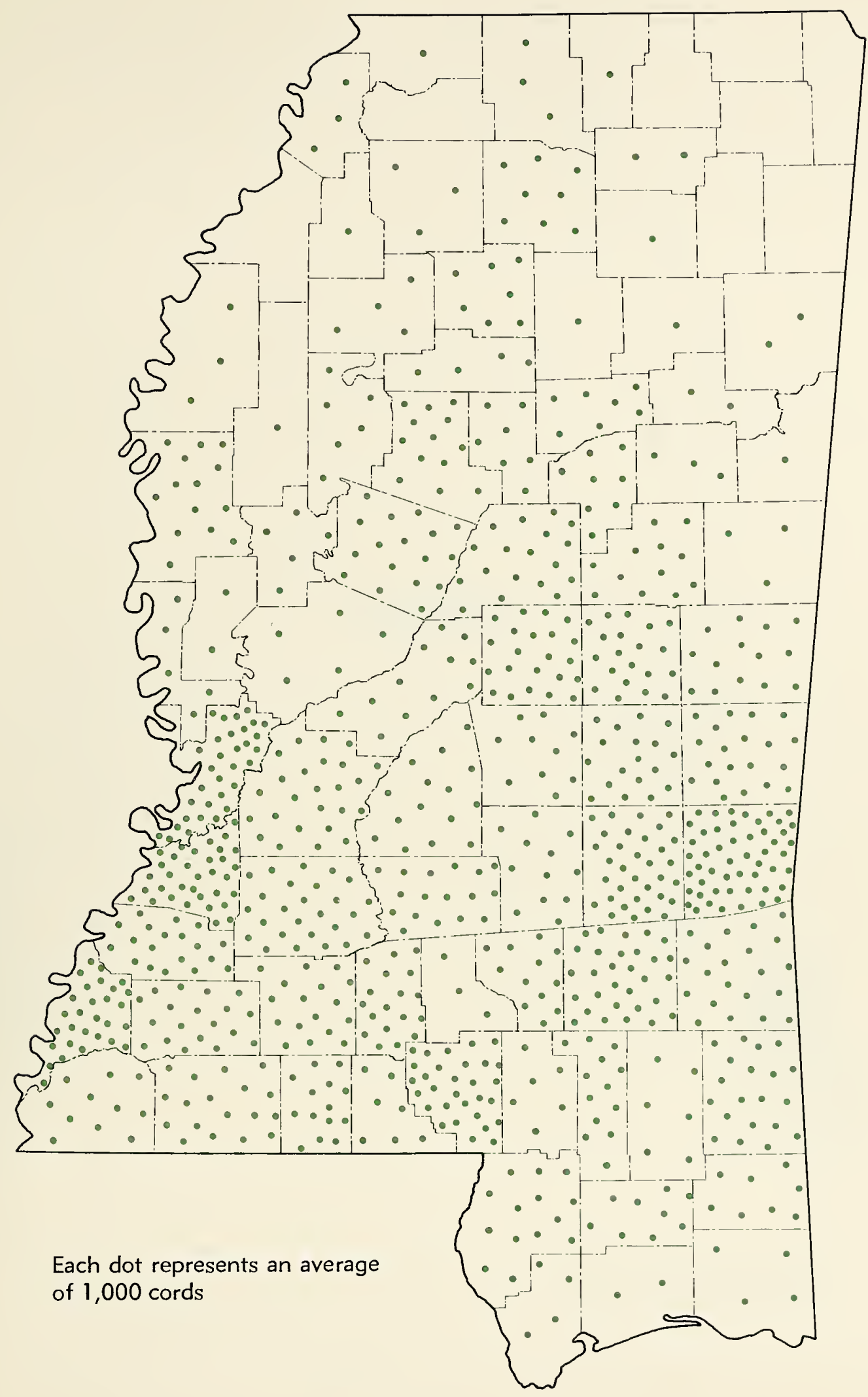

Figure 30. Output of hardwood pulpwood, 1959. Source: State Tax Commission. 


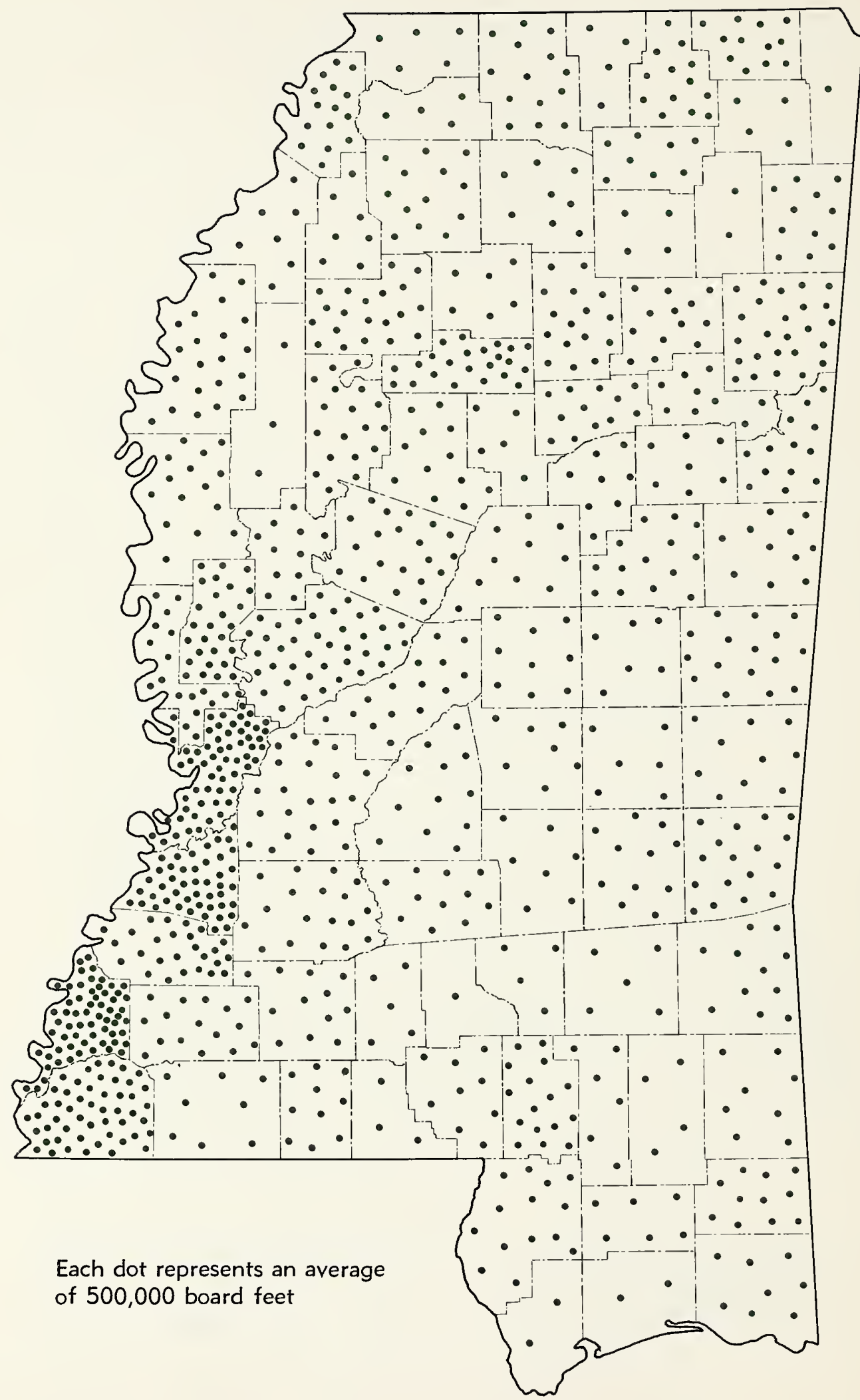

Figure 31. Output of industrial hardwood products (except pulpwood), 1959. Source: State Tax Commission. 
Tables 
Table 2. Growing stock volume by species group and county

\begin{tabular}{|c|c|c|c|c|c|c|c|c|c|c|}
\hline \multirow[b]{2}{*}{ County } & \multirow{2}{*}{$\begin{array}{c}\text { All } \\
\text { species }\end{array}$} & \multicolumn{3}{|c|}{ Softwood } & \multicolumn{3}{|c|}{$\begin{array}{c}\text { Soft } \\
\text { hardwood }\end{array}$} & \multicolumn{3}{|c|}{$\begin{array}{c}\text { Hard } \\
\text { hardwood }\end{array}$} \\
\hline & & Total & Pine & Other & Total & Gum & Other $^{1}$ & Total & Oak & Other \\
\hline & \multicolumn{10}{|c|}{------------ Million cubic feet ------------} \\
\hline Adams & 116.6 & 29.4 & 29.4 & $\ldots$ & 34.6 & 13.7 & 20.9 & 52.6 & 26.6 & 26.0 \\
\hline Alcorn & 42.1 & 9.6 & 9.0 & .6 & 9.3 & 5.1 & 4.2 & 23.2 & 16.2 & 7.0 \\
\hline Amite & 129.8 & 85.7 & 85.5 & .2 & 11.3 & 9.5 & 1.8 & 32.8 & 27.6 & 5.2 \\
\hline Attala & 68.8 & 22.1 & 21.0 & 1.1 & 22.6 & 19.0 & 3.6 & 24.1 & 15.2 & 8.9 \\
\hline Benton & 60.4 & 21.7 & 21.6 & .1 & 11.8 & 7.6 & 4.2 & 26.9 & 19.0 & 7.9 \\
\hline Bolivar & 60.1 & 7.7 & & 7.7 & 33.0 & 6.7 & 26.3 & 19.4 & 5.3 & 14.1 \\
\hline Calhoun & 76.2 & 32.9 & 32.9 & $\ldots$ & 13.5 & 12.0 & 1.5 & 29.8 & 21.9 & 7.9 \\
\hline Carroll & 67.0 & 4.0 & 4.0 & $\ldots$ & 23.4 & 19.3 & 4.1 & 39.6 & 27.2 & 12.4 \\
\hline Chickasaw & 32.4 & 13.5 & 13.5 & $\ldots$ & 3.0 & 3.0 & $\ldots$ & 15.9 & 12.4 & 3.5 \\
\hline Choctaw & 59.1 & 30.6 & 30.6 & & 12.5 & 9.7 & 2.8 & 16.0 & 13.3 & 2.7 \\
\hline Claiborne & 129.4 & 12.8 & 12.2 & .6 & 49.8 & 29.8 & 20.0 & 66.8 & 28.7 & 38.1 \\
\hline Clarke & 188.9 & 126.6 & 126.3 & .3 & 25.7 & 20.9 & 4.8 & 36.6 & 27.3 & 9.3 \\
\hline Clay & 73.5 & 4.4 & 4.1 & .3 & 9.2 & 7.1 & 2.1 & 59.9 & 44.8 & 15.1 \\
\hline Coahoma & 50.8 & 1.3 & $\ldots$ & 1.3 & 14.1 & 2.3 & 11.8 & 35.4 & 5.5 & 29.9 \\
\hline Copiah & 174.6 & 94.9 & 94.5 & .4 & 33.5 & 27.9 & 5.6 & 46.2 & 29.0 & 17.2 \\
\hline Covington & 61.2 & 15.5 & 15.5 & $\ldots$ & 29.0 & 21.6 & 7.4 & 16.7 & 10.4 & 6.3 \\
\hline De Soto & 43.2 & 1.6 & $\ldots$ & 1.6 & 15.8 & 11.3 & 4.5 & 25.8 & 10.9 & 14.9 \\
\hline Forrest & 82.2 & 58.1 & 58.1 & $\ldots$ & 16.2 & 10.4 & 5.8 & 7.9 & 6.0 & 1.9 \\
\hline Franklin & 191.8 & 134.5 & 134.5 & $\ldots$ & 19.7 & 15.2 & 4.5 & 37.6 & 23.0 & 14.6 \\
\hline George & 125.3 & 75.3 & 71.8 & 3.5 & 31.6 & 16.9 & 14.7 & 18.4 & 9.7 & 8.7 \\
\hline Greene & 141.0 & 84.5 & 83.6 & .9 & 27.7 & 19.6 & 8.1 & 28.8 & 24.0 & 4.8 \\
\hline Grenada & 51.2 & 16.2 & 15.8 & .4 & 14.9 & 14.5 & .4 & 20.1 & 10.5 & 9.6 \\
\hline Hancock & 74.4 & 43.6 & 43.3 & .3 & 27.8 & 20.3 & 7.5 & 3.0 & 3.0 & \\
\hline Harrison & 123.4 & 96.4 & 96.4 & $\ldots$ & 23.0 & 10.1 & 12.9 & 4.0 & 1.2 & 2.8 \\
\hline Hinds & 82.6 & 15.2 & 14.5 & .7 & 25.2 & 18.9 & 6.3 & 42.2 & 25.0 & 17.2 \\
\hline Holmes & 82.1 & 21.6 & 20.8 & .8 & 26.0 & 18.0 & 8.0 & 34.5 & 24.1 & 10.4 \\
\hline Humphreys & 35.8 & $\ldots$ & $\ldots$ & $\ldots$ & 6.1 & 6.1 & $\ldots$ & 29.7 & 24.7 & 5.0 \\
\hline Issaquena & 84.0 & 3.1 & & 3.1 & 15.1 & 5.1 & 10.0 & 65.8 & 24.1 & 41.7 \\
\hline Itawamba , & 76.8 & 22.0 & 21.9 & .1 & 22.8 & 15.5 & 7.3 & 32.0 & 16.8 & 15.2 \\
\hline Jackson & 159.9 & 90.3 & 86.3 & 4.0 & 55.5 & 44.9 & 10.6 & 14.1 & 9.8 & 4.3 \\
\hline Jasper & 191.2 & 113.7 & 111.9 & 1.8 & 41.0 & 29.7 & 11.3 & 36.5 & 19.8 & 16.7 \\
\hline Jefferson & 165.9 & 101.3 & 63.4 & 37.9 & 28.7 & 17.9 & 10.8 & 35.9 & 16.8 & 19.1 \\
\hline Jefferson Davis & 62.4 & 23.6 & 23.6 & $\ldots$ & 21.5 & 16.1 & 5.4 & 17.3 & 10.8 & 6.5 \\
\hline Jones & 115.4 & 64.2 & 64.2 & $\ldots$ & 22.0 & 11.3 & 10.7 & 29.2 & 22.9 & 6.3 \\
\hline Kemper & 143.9 & 69.3 & 68.2 & 1.1 & 42.7 & 39.9 & 2.8 & 31.9 & 20.7 & 11.2 \\
\hline Lafayette & 117.5 & 38.9 & 38.8 & .1 & 21.2 & 17.8 & 3.4 & 57.4 & 45.1 & 12.3 \\
\hline Lamar & 109.9 & 76.5 & 76.5 & $\ldots$ & 21.5 & 9.3 & 12.2 & 11.9 & 9.5 & 2.4 \\
\hline Lauderdale & 163.5 & 91.7 & 91.7 & $\ldots$ & 26.3 & 21.1 & 5.2 & 45.5 & 30.1 & 15.4 \\
\hline Lawrence & 96.7 & 43.6 & 43.6 & $\ldots$ & 14.1 & 12.0 & 2.1 & 39.0 & 26.2 & 12.8 \\
\hline Leake & 95.5 & 52.4 & 52.3 & .1 & 15.6 & 13.5 & 2.1 & 27.5 & 24.8 & 2.7 \\
\hline Lee & 14.4 & 5.2 & 5.2 & $\ldots$ & 1.5 & .7 & .8 & 7.7 & 4.9 & 2.8 \\
\hline Leflore & 31.0 & $\ldots$ & $\ldots$ & $\ldots$ & 9.3 & 9.3 & $\ldots$ & 21.7 & 10.6 & 11.1 \\
\hline
\end{tabular}


Table 2. Growing stock volume by species group and county (Continued)

\begin{tabular}{|c|c|c|c|c|c|c|c|c|c|c|}
\hline \multirow[b]{2}{*}{ County } & \multirow{2}{*}{$\begin{array}{c}\text { All } \\
\text { species }\end{array}$} & \multicolumn{3}{|c|}{ Softwood } & \multicolumn{3}{|c|}{$\begin{array}{l}\text { Soft } \\
\text { hardwood }\end{array}$} & \multicolumn{3}{|c|}{$\begin{array}{l}\text { Hard } \\
\text { hardwood }\end{array}$} \\
\hline & & Total & Pine & Other & Total & Gum & Other ${ }^{1}$ & Total & Oak & Other $^{2}$ \\
\hline & \multicolumn{10}{|c|}{------------- Million cubic feet ---------------} \\
\hline Lincoln & 112.1 & 54.2 & 53.8 & .4 & 22.0 & 12.7 & 9.3 & 35.9 & 23.0 & 12.9 \\
\hline Lowndes & 52.3 & 11.1 & 6.2 & 4.9 & 15.1 & 12.3 & 2.8 & 26.1 & 14.7 & 11.4 \\
\hline Madison & 75.5 & 23.9 & 22.5 & 1.4 & 16.4 & 13.5 & 2.9 & 35.2 & 20.9 & 14.3 \\
\hline Marion & 128.2 & 59.6 & 59.6 & $\ldots$ & 25.2 & 20.1 & 5.1 & 43.4 & 29.6 & 13.8 \\
\hline Marshall & 73.5 & 12.8 & 11.3 & 1.5 & 29.2 & 14.1 & 15.1 & 31.5 & 23.6 & 7.9 \\
\hline Monroe & 79.7 & 20.8 & 20.8 & $\ldots$ & 21.3 & 18.1 & 3.2 & 37.6 & 26.9 & 10.7 \\
\hline Montgomery & 36.9 & 14.5 & 14.5 & $\cdots$ & 6.0 & 5.8 & .2 & 16.4 & 12.1 & 4.3 \\
\hline Neshoba & 135.4 & 56.2 & 56.2 & $\ldots$ & 40.6 & 36.9 & 3.7 & 38.6 & 30.0 & 8.6 \\
\hline Newton & 89.8 & 37.2 & 37.2 & $\ldots$ & 16.4 & 13.0 & 3.4 & 36.2 & 26.3 & 9.9 \\
\hline Noxubee & 102.8 & 52.6 & 52.3 & .3 & 9.3 & 9.3 & $\ldots$ & 40.9 & 29.1 & 11.8 \\
\hline Oktibbeha & 58.0 & 25.7 & 24.1 & 1.6 & 3.1 & 2.4 & .7 & 29.2 & 23.8 & 5.4 \\
\hline Panola & 33.7 & .7 & & .7 & 14.0 & 10.4 & 3.6 & 19.0 & 11.5 & 7.5 \\
\hline Pearl River & 156.2 & 91.0 & 91.0 & $\ldots$ & 53.6 & 24.3 & 29.3 & 11.6 & 9.7 & 1.9 \\
\hline Perry & 152.4 & 113.4 & 112.9 & .5 & 22.5 & 17.0 & 5.5 & 16.5 & 14.5 & 2.0 \\
\hline Pike & $\mathbf{7 7 . 7}$ & 25.0 & 25.0 & $\cdots$ & 20.5 & 18.7 & 1.8 & 32.2 & 23.9 & 8.3 \\
\hline Pontotoc & 38.7 & 14.2 & 14.2 & $\ldots$ & 4.5 & 4.3 & .2 & 20.0 & 10.0 & 10.0 \\
\hline Prentiss & 31.8 & 8.0 & 7.9 & .1 & 6.9 & 6.0 & .9 & 16.9 & 13.4 & 3.5 \\
\hline Quitman & 24.6 & 1.8 & . & 1.8 & 11.2 & 8.4 & 2.8 & 11.6 & 5.0 & 6.6 \\
\hline Rankin & 188.0 & 81.7 & 78.9 & 2.8 & 27.0 & 25.7 & 1.3 & 79.3 & 57.3 & 22.0 \\
\hline Scott & 140.3 & 100.7 & 100.7 & & 14.7 & 13.5 & 1.2 & 24.9 & 17.6 & 7.3 \\
\hline Sharkey & 49.0 & 2.5 & $\ldots$ & 2.5 & 9.9 & 9.6 & .3 & 36.6 & 23.7 & 12.9 \\
\hline Simpson & 94.7 & 41.3 & 41.3 & $\cdots$ & 19.3 & 17.4 & 1.9 & 34.1 & 23.3 & 10.8 \\
\hline Smith & 132.0 & 81.8 & 81.8 & $\ldots$ & 24.4 & 20.7 & 3.7 & 25.8 & 20.7 & 5.1 \\
\hline Stone & 100.7 & 61.6 & 60.3 & 1.3 & 28.7 & 13.0 & 15.7 & 10.4 & 9.9 & .5 \\
\hline Sunflower & 8.6 & 2.6 & $\ldots$ & 2.6 & .6 & $\ldots$ & .6 & 5.4 & 4.7 & .7 \\
\hline Tallahatchie & 46.6 & 8.5 & 4.7 & 3.8 & 11.5 & 11.5 & $\ldots$ & 26.6 & 18.0 & 8.6 \\
\hline Tate & 33.4 & .1 & $\ldots$ & .1 & 14.7 & 11.9 & 2.8 & 18.6 & 4.7 & 13.9 \\
\hline Tippah & 51.3 & 14.7 & 14.7 & $\ldots$ & 9.8 & 7.1 & 2.7 & 26.8 & 19.5 & 7.3 \\
\hline Tishomingo & 79.9 & 39.2 & 39.2 & $\ldots$ & 17.0 & 12.1 & 4.9 & 23.7 & 17.4 & 6.3 \\
\hline Tunica & 59.5 & 2.5 & $\cdots$ & 2.5 & 30.6 & 3.2 & 27.4 & 26.4 & 4.0 & 22.4 \\
\hline Union & 55.7 & 19.3 & 19.3 & .. & 18.4 & 12.8 & 5.6 & 18.0 & 11.9 & 6.1 \\
\hline Walthall & 48.8 & 14.6 & 12.4 & 2.2 & 24.9 & 18.6 & 6.3 & 9.3 & 7.3 & 2.0 \\
\hline Warren & 153.5 & 6.3 & 3.9 & 2.4 & 67.9 & 33.8 & 34.1 & 79.3 & 38.2 & 41.1 \\
\hline Washington & 55.3 & .5 & $\ldots$ & .5 & 27.4 & 7.8 & 19.6 & 27.4 & 10.3 & 17.1 \\
\hline Wayne & 199.6 & 134.5 & 134.5 & $\ldots$ & 24.3 & 17.6 & 6.7 & 40.8 & 31.4 & 9.4 \\
\hline Webster & 42.4 & 18.8 & 18.8 & $\ldots$ & 5.7 & 4.6 & 1.1 & 17.9 & 13.1 & 4.8 \\
\hline Wilkinson & 215.5 & 124.7 & 116.1 & 8.6 & 27.9 & 23.9 & 4.0 & 62.9 & 25.3 & 37.6 \\
\hline Winston & 154.2 & 62.8 & 62.8 & $\ldots$ & 33.2 & 29.1 & 4.1 & 58.2 & 43.5 & 14.7 \\
\hline Yalobusha & 49.0 & 12.2 & 11.7 & .5 & 9.2 & 6.3 & 2.9 & 27.6 & 23.1 & 4.5 \\
\hline Yazoo & 119.8 & 4.2 & 1.5 & 2.7 & 38.6 & 28.0 & 10.6 & 77.0 & 37.4 & 39.6 \\
\hline All counties & $7,589.0$ & $3,313.3$ & $3,198.6$ & 114.7 & $1,752.6$ & $1,216.1$ & 536.5 & $2,523.1$ & $1,595.7$ & 927.4 \\
\hline
\end{tabular}

${ }^{1}$ Includes cottonwood, willow, yellow-poplar, and the like.

2 Includes ash, hickory, sycamore, and the like. 
Table 3. Growing stock volume by diameter group and county

\begin{tabular}{|c|c|c|c|c|c|c|c|c|c|c|}
\hline \multirow[b]{2}{*}{ County } & \multirow[b]{2}{*}{$\begin{array}{c}\text { All } \\
\text { species }\end{array}$} & \multicolumn{3}{|c|}{ Softwood } & \multicolumn{3}{|c|}{ Soft hardwood } & \multicolumn{3}{|c|}{ Hard hardwood } \\
\hline & & Total & $\begin{array}{c}6-12 \\
\text { inches }\end{array}$ & $\begin{array}{c}14 \text { inches } \\
\text { and up }\end{array}$ & Total & $\begin{array}{c}6-12 \\
\text { inches }\end{array}$ & $\begin{array}{l}14 \text { inches } \\
\text { and up }\end{array}$ & Total & $\begin{array}{c}6-12 \\
\text { inches }\end{array}$ & $\begin{array}{c}14 \text { inches } \\
\text { and up }\end{array}$ \\
\hline & \multicolumn{10}{|c|}{-------------- Million cubic feet --------------} \\
\hline Adams & 116.6 & 29.4 & 6.6 & 22.8 & 34.6 & 10.6 & 24.0 & 52.6 & 17.9 & 34.7 \\
\hline Alcorn & 42.1 & 9.6 & 7.7 & 1.9 & 9.3 & 5.2 & 4.1 & 23.2 & 16.7 & 6.5 \\
\hline Amite & 129.8 & 85.7 & 43.0 & 42.7 & 11.3 & 8.2 & 3.1 & 32.8 & 19.7 & 13.1 \\
\hline Attala & 68.8 & 22.1 & 18.4 & 3.7 & 22.6 & 14.4 & 8.2 & 24.1 & 13.2 & 10.9 \\
\hline Benton & 60.4 & 21.7 & 19.0 & 2.7 & 11.8 & 8.1 & 3.7 & 26.9 & 21.4 & 5.5 \\
\hline Bolivar & 60.1 & 7.7 & 2.3 & 5.4 & 33.0 & 8.1 & 24.9 & 19.4 & 8.7 & 10.7 \\
\hline Calhoun & 76.2 & 32.9 & 29.5 & 3.4 & 13.5 & 6.1 & 7.4 & 29.8 & 14.9 & 14.9 \\
\hline Carroll & 67.0 & 4.0 & 3.3 & .7 & 23.4 & 16.3 & 7.1 & 39.6 & 19.1 & 20.5 \\
\hline Chickasaw & 32.4 & 13.5 & 10.0 & 3.5 & 3.0 & 2.4 & .6 & 15.9 & 11.4 & 4.5 \\
\hline Choctaw & 59.1 & 30.6 & 24.4 & 6.2 & 12.5 & 9.3 & 3.2 & 16.0 & 13.9 & 2.1 \\
\hline Claiborne & 129.4 & 12.8 & 7.1 & 5.7 & 49.8 & 11.6 & 38.2 & 66.8 & 28.2 & 38.6 \\
\hline Clarke & 188.9 & 126.6 & 77.6 & 49.0 & 25.7 & 17.0 & 8.7 & 36.6 & 24.5 & 12.1 \\
\hline Clay & 73.5 & 4.4 & 2.9 & 1.5 & 9.2 & 7.3 & 1.9 & 59.9 & 37.1 & 22.8 \\
\hline Coahoma & 50.8 & 1.3 & . & 1.3 & 14.1 & 6.1 & 8.0 & 35.4 & 15.1 & 20.3 \\
\hline Copiah & 174.6 & 94.9 & 34.2 & 60.7 & 33.5 & 19.5 & 14.0 & 46.2 & 22.8 & 23.4 \\
\hline Covington & 61.2 & 15.5 & 7.5 & 8.0 & 29.0 & 14.3 & 14.7 & 16.7 & 7.7 & 9.0 \\
\hline De Soto & 43.2 & 1.6 & .6 & 1.0 & 15.8 & 9.3 & 6.5 & 25.8 & 12.2 & 13.6 \\
\hline Forrest & 82.2 & 58.1 & 43.3 & 14.8 & 16.2 & 10.3 & 5.9 & 7.9 & 3.8 & 4.1 \\
\hline Franklin & 191.8 & 134.5 & 63.0 & 71.5 & 19.7 & 13.3 & 6.4 & 37.6 & 18.6 & 19.0 \\
\hline George & 125.3 & 75.3 & 43.9 & 31.4 & 31.6 & 20.6 & 11.0 & 18.4 & 10.7 & 7.7 \\
\hline Greene & 141.0 & 84.5 & 47.6 & 36.9 & 27.7 & 15.1 & 12.6 & 28.8 & 18.4 & 10.4 \\
\hline Grenada & 51.2 & 16.2 & 10.2 & 6.0 & 14.9 & 6.9 & 8.0 & 20.1 & 11.3 & 8.8 \\
\hline Hancock & 74.4 & 43.6 & 32.9 & 10.7 & 27.8 & 21.4 & 6.4 & 3.0 & 2.1 & .9 \\
\hline Harrison & 123.4 & 96.4 & 74.4 & 22.0 & 23.0 & 13.5 & 9.5 & 4.0 & 3.2 & .8 \\
\hline Hinds & 82.6 & 15.2 & 9.8 & 5.4 & 25.2 & 12.7 & 12.5 & 42.2 & 22.9 & 19.3 \\
\hline Holmes & 82.1 & 21.6 & 16.3 & 5.3 & 26.0 & 9.5 & 16.5 & 34.5 & 13.7 & 20.8 \\
\hline Humphreys & 35.8 & $\ldots$ & $\ldots$ & $\ldots$ & 6.1 & 3.6 & 2.5 & 29.7 & 9.3 & 20.4 \\
\hline Issaquena & 84.0 & 3.1 & .3 & 2.8 & 15.1 & 1.6 & 13.5 & 65.8 & 21.0 & 44.8 \\
\hline Itawamba & 76.8 & 22.0 & 20.2 & 1.8 & 22.8 & 12.5 & 10.3 & 32.0 & 18.8 & 13.2 \\
\hline Jackson & 159.9 & 90.3 & 63.2 & 27.1 & 55.5 & 19.3 & 36.2 & 14.1 & 4.7 & 9.4 \\
\hline Jasper & 191.2 & 113.7 & $\mathbf{5 5 . 0}$ & 58.7 & 41.0 & 19.4 & 21.6 & 36.5 & 19.3 & 17.2 \\
\hline Jefferson & 165.9 & 101.3 & 32.0 & 69.3 & 28.7 & 11.2 & 17.5 & 35.9 & 17.4 & 18.5 \\
\hline Jefferson Davis & 62.4 & 23.6 & 14.9 & 8.7 & 21.5 & 17.5 & 4.0 & 17.3 & 8.9 & 8.4 \\
\hline Jones & 115.4 & 64.2 & 38.8 & 25.4 & 22.0 & 17.7 & 4.3 & 29.2 & 17.5 & 11.7 \\
\hline Kemper & 143.9 & 69.3 & 44.0 & 25.3 & 42.7 & 37.4 & 5.3 & 31.9 & 21.4 & 10.5 \\
\hline Lafayette & 117.5 & 38.9 & 26.0 & 12.9 & 21.2 & 11.5 & 9.7 & 57.4 & 20.3 & 37.1 \\
\hline Lamar & 109.9 & 76.5 & 50.1 & 26.4 & 21.5 & 11.9 & 9.6 & 11.9 & 8.1 & 3.8 \\
\hline Lauderdale & 163.5 & 91.7 & 69.9 & 21.8 & 26.3 & 20.2 & 6.1 & 45.5 & 33.1 & 12.4 \\
\hline Lawrence & 96.7 & 43.6 & 31.2 & 12.4 & 14.1 & 7.7 & 6.4 & 39.0 & 21.3 & 17.7 \\
\hline Leake & 95.5 & 52.4 & 40.9 & 11.5 & 15.6 & 12.1 & 3.5 & 27.5 & 19.0 & 8.5 \\
\hline Lee & 14.4 & 5.2 & 1.7 & 3.5 & 1.5 & .8 & .7 & 7.7 & 3.8 & 3.9 \\
\hline Leflore & 31.0 & $\ldots$ & $\ldots$ & $\ldots$ & 9.3 & 4.0 & 5.3 & 21.7 & 8.3 & 13.4 \\
\hline
\end{tabular}


Table 3. Growing stock volume by diameter group and county (Continued)

\begin{tabular}{|c|c|c|c|c|c|c|c|c|c|c|}
\hline \multirow[b]{2}{*}{ County } & \multirow[b]{2}{*}{$\underset{\text { species }}{\text { All }}$} & \multicolumn{3}{|c|}{ Softwood } & \multicolumn{3}{|c|}{ Soft hardwood } & \multicolumn{3}{|c|}{ Hard hardwood } \\
\hline & & Total & $\begin{array}{c}6-12 \\
\text { inches }\end{array}$ & $\begin{array}{l}14 \text { inches } \\
\text { and up }\end{array}$ & Total & $\begin{array}{c}6-12 \\
\text { inches }\end{array}$ & $\begin{array}{c}14 \text { inches } \\
\text { and up }\end{array}$ & Total & $\begin{array}{c}6-12 \\
\text { inches }\end{array}$ & $\begin{array}{l}14 \text { inches } \\
\text { and up }\end{array}$ \\
\hline & -- & --- & --- & ---1 & illion & ibic fec & $t----$ & --- & --- & --- \\
\hline Lincoln & 112.1 & 54.2 & 24.5 & 29.7 & 22.0 & 11.3 & 10.7 & 35.9 & 17.2 & 18.7 \\
\hline Lowndes & 52.3 & 11.1 & 5.0 & 6.1 & 15.1 & 10.7 & 4.4 & 26.1 & 18.8 & 7.3 \\
\hline Madison & 75.5 & 23.9 & 10.7 & 13.2 & 16.4 & 7.9 & 8.5 & 35.2 & 19.0 & 16.2 \\
\hline Marion & 128.2 & 59.6 & 31.3 & 28.3 & 25.2 & 13.6 & 11.6 & 43.4 & 24.8 & 18.6 \\
\hline Marzhall & 73.5 & 12.8 & 7.0 & 5.8 & 29.2 & 15.9 & 13.3 & 31.5 & 11.0 & 20.5 \\
\hline Monroe & 79.7 & 20.8 & 9.0 & 11.8 & 21.3 & 16.3 & 5.0 & 37.6 & 26.5 & 11.1 \\
\hline Montgomery & 36.9 & 14.5 & 9.8 & 4.7 & 6.0 & 5.6 & .4 & 16.4 & 8.6 & 7.8 \\
\hline Neshoba & 135.4 & 56.2 & 38.0 & 18.2 & 40.6 & 27.5 & 13.1 & 38.6 & 22.3 & 16.3 \\
\hline Newton & 89.8 & 37.2 & 30.8 & 6.4 & 16.4 & 11.3 & 5.1 & 36.2 & 16.5 & 19.7 \\
\hline Noxubee & 102.8 & 52.6 & 30.2 & 22.4 & 9.3 & 8.0 & 1.3 & 40.9 & 28.2 & 12.7 \\
\hline Oktibbeha & 58.0 & 25.7 & 11.1 & 14.6 & 3.1 & 2.7 & .4 & 29.2 & 21.6 & 7.6 \\
\hline Panola & 33.7 & $\begin{array}{lll}.7 & r & \end{array}$ & .7 & & 14.0 & 7.4 & 6.6 & 19.0 & 8.1 & 10.9 \\
\hline Pearl River & 156.2 & 91.0 & 57.1 & 33.9 & 53.6 & 30.5 & 23.1 & 11.6 & 6.4 & 5.2 \\
\hline Perry & 152.4 & 113.4 & 70.6 & 42.8 & 22.5 & 16.3 & 6.2 & 16.5 & 9.9 & 6.6 \\
\hline Pike & 77.7 & 25.0 & 18.4 & 6.6 & 20.5 & 9.7 & 10.8 & 32.2 & 12.9 & 19.3 \\
\hline Pontotoc & 38.7 & 14.2 & 12.2 & 2.0 & 4.5 & 2.8 & 1.7 & 20.0 & 15.4 & 4.6 \\
\hline Prentiss & 31.8 & 8.0 & 7.8 & .2 & 6.9 & 5.1 & 1.8 & 16.9 & 12.2 & 4.7 \\
\hline Quitman & 24.6 & 1.8 & $\ldots$ & 1.8 & 11.2 & 2.6 & 8.6 & 11.6 & 6.8 & 4.8 \\
\hline Rankin & 188.0 & 81.7 & 49.8 & 31.9 & 27.0 & 18.3 & 8.7 & 79.3 & 40.8 & 38.5 \\
\hline Scott & 140.3 & 100.7 & 61.4 & 39.3 & 14.7 & 8.5 & 6.2 & 24.9 & 17.5 & 7.4 \\
\hline Sharkey & 49.0 & 2.5 & & 2.5 & 9.9 & 1.9 & 8.0 & 36.6 & 9.3 & 27.3 \\
\hline Simpson & 94.7 & 41.3 & 19.9 & 21.4 & 19.3 & 14.5 & 4.8 & 34.1 & 23.8 & 10.3 \\
\hline Smith & 132.0 & 81.8 & 59.7 & 22.1 & 24.4 & 19.6 & 4.8 & 25.8 & 18.9 & 6.9 \\
\hline Stone & 100.7 & 61.6 & 36.5 & 25.1 & 28.7 & 19.8 & 8.9 & 10.4 & 6.8 & 3.6 \\
\hline Sunflower & 8.6 & 2.6 & .7 & 1.9 & .6 & $\ldots$ & .6 & 5.4 & 4.2 & 1.2 \\
\hline Tallahatchie & 46.6 & 8.5 & 6.9 & 1.6 & 11.5 & 4.1 & 7.4 & 26.6 & 9.0 & 17.6 \\
\hline Tate & 33.4 & .1 & .1 & $\ldots$ & 14.7 & 6.4 & 8.3 & 18.6 & 13.1 & 5.5 \\
\hline Tippah & 51.3 & 14.7 & 14.1 & .6 & 9.8 & 6.3 & 3.5 & 26.8 & 16.2 & 10.6 \\
\hline Tishomingo & 79.9 & 39.2 & 30.4 & 8.8 & 17.0 & 8.2 & 8.8 & 23.7 & 14.5 & 9.2 \\
\hline Tunica & 59.5 & 2.5 & .2 & 2.3 & 30.6 & 5.9 & 24.7 & 26.4 & 8.4 & 18.0 \\
\hline Union & 55.7 & 19.3 & 16.2 & 3.1 & 18.4 & 12.3 & 6.1 & 18.0 & 9.2 & 8.8 \\
\hline Walthall & 48.8 & 14.6 & 8.2 & 6.4 & 24.9 & 13.6 & 11.3 & 9.3 & 6.4 & 2.9 \\
\hline Warren & 153.5 & 6.3 & 1.8 & 4.5 & 67.9 & 20.3 & 47.6 & 79.3 & 25.2 & 54.1 \\
\hline Washington & 55.3 & .5 & & .5 & 27.4 & 7.4 & 20.0 & 27.4 & 9.7 & 17.7 \\
\hline Wayne & 199.6 & 134.5 & 85.7 & 48.8 & 24.3 & 18.1 & 6.2 & 40.8 & 29.8 & 11.0 \\
\hline Webster & 42.4 & 18.8 & 16.6 & 2.2 & 5.7 & 4.4 & 1.3 & 17.9 & 14.0 & 3.9 \\
\hline Wilkinson & 215.5 & 124.7 & 52.2 & 72.5 & 27.9 & 15.9 & 12.0 & 62.9 & 24.0 & 38.9 \\
\hline Winston & 154.2 & 62.8 & 41.5 & 21.3 & 33.2 & 16.6 & 16.6 & 58.2 & 35.9 & 22.3 \\
\hline Yalobusha & 49.0 & 12.2 & 7.7 & 4.5 & 9.2 & 7.0 & 2.2 & 27.6 & 17.0 & 10.6 \\
\hline Yazoo & 119.8 & 4.2 & 1.6 & 2.6 & 38.6 & 14.3 & 24.3 & 77.0 & $25: 4$ & 51.6 \\
\hline Total & $7,589.0$ & $3,313.3$ & $2,009.1$ & $1,304.2$ & $1,752.6$ & 954.1 & 798.5 & $2,523.1$ & $1,326.7$ & $1,196.4$ \\
\hline
\end{tabular}


Table 4. Sawtimber volume by species group and county

\begin{tabular}{|c|c|c|c|c|c|c|c|c|c|c|}
\hline \multirow[b]{2}{*}{ County } & \multirow{2}{*}{$\begin{array}{c}\text { All } \\
\text { species }\end{array}$} & \multicolumn{3}{|c|}{ Softwood } & \multicolumn{3}{|c|}{$\begin{array}{c}\text { Soft } \\
\text { hardwood }\end{array}$} & \multicolumn{3}{|c|}{$\begin{array}{c}\text { Hard } \\
\text { hardwood }\end{array}$} \\
\hline & & Total & Pine & Other & Total & Gum & Other ${ }^{1}$ & Total & Oak & Other : \\
\hline & \multicolumn{10}{|c|}{ 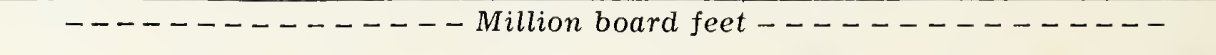 } \\
\hline Adams & 493.2 & 155.2 & 155.2 & $\ldots$ & 141.7 & 47.4 & 94.3 & 196.3 & 106.6 & 89.7 \\
\hline Alcorn & 102.5 & 21.1 & 17.2 & 3.9 & 31.0 & 15.0 & 16.0 & 50.4 & 36.1 & 14.3 \\
\hline Amite & 501.8 & 394.6 & 394.6 & & 23.0 & 19.0 & 4.0 & 84.2 & 70.9 & 13.3 \\
\hline Attala & 160.3 & 50.9 & 45.2 & 5.7 & 43.7 & 34.8 & 8.9 & 65.7 & 44.5 & 21.2 \\
\hline Benton & 147.3 & 78.0 & 78.0 & & 24.6 & 13.8 & 10.8 & 44.7 & 38.9 & 5.8 \\
\hline Bolivar & 240.7 & 39.7 & $\ldots$ & 39.7 & 143.3 & 28.3 & 115.0 & 57.7 & 17.4 & 40.3 \\
\hline Calhoun & 234.6 & 92.1 & 92.1 & .. & 48.7 & 39.6 & 9.1 & 93.8 & 71.7 & 22.1 \\
\hline Carroll & 176.8 & 7.5 & 7.5 & $\ldots$ & 44.7 & 37.8 & 6.9 & 124.6 & 84.0 & 40.6 \\
\hline Chickasaw & 72.1 & 44.3 & 44.3 & .. & 2.9 & 2.9 & & 24.9 & 19.8 & 5.1 \\
\hline Choctaw & 140.7 & 91.7 & 91.7 & $\ldots$ & 28.1 & 16.7 & 11.4 & 20.9 & 18.0 & 2.9 \\
\hline Claiborne & 501.8 & 56.6 & 53.8 & 2.8 & 220.3 & 121.8 & 98.5 & 224.9 & 111.6 & 113.3 \\
\hline Clarke & 735.9 & 597.5 & 596.0 & 1.5 & 65.5 & 50.3 & 15.2 & 72.9 & 46.0 & 26.9 \\
\hline Clay & 192.5 & 19.6 & 18.0 & 1.6 & 15.7 & 15.7 & $\ldots$ & 157.2 & 116.9 & 40.3 \\
\hline Coahoma & 173.6 & 6.5 & $\ldots$ & 6.5 & 49.0 & 3.4 & 45.6 & 118.1 & 13.9 & 104.2 \\
\hline Copiah & 701.7 & 480.2 & 479.4 & .8 & 86.7 & 68.6 & 18.1 & 134.8 & 92.8 & 42.0 \\
\hline Covington & 201.3 & 63.7 & 63.7 & $\ldots$ & 85.5 & 57.5 & 28.0 & 52.1 & 28.8 & 23.3 \\
\hline De Soto & 130.3 & 5.6 & $\ldots$ & 5.6 & 41.8 & 32.8 & 9.0 & 82.9 & 36.1 & 46.8 \\
\hline Forrest & 280.2 & 221.1 & 221.1 & $\ldots$ & 37.4 & 22.7 & 14.7 & 21.7 & 18.6 & 3.1 \\
\hline Franklin & 768.7 & 606.4 & 606.4 & $\ldots$ & 45.9 & 25.6 & 20.3 & 116.4 & 67.4 & 49.0 \\
\hline George & 430.2 & 299.2 & 281.4 & 17.8 & 87.9 & 37.0 & 50.9 & 43.1 & 18.4 & 24.7 \\
\hline Greene & 545.7 & 377.1 & 372.5 & 4.6 & 89.3 & 73.1 & 16.2 & 79.3 & 65.6 & 13.7 \\
\hline Grenada & 154.2 & 51.3 & 51.3 & $\ldots$ & 52.0 & 52.0 & & 50.9 & 28.2 & 22.7 \\
\hline Hancock & 220.8 & 166.4 & 166.4 & $\ldots$ & 49.6 & 33.3 & 16.3 & 4.8 & 4.8 & 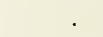 \\
\hline Harrison & 422.1 & 352.5 & 352.5 & $\ldots$ & 63.8 & 22.8 & 41.0 & 5.8 & 2.9 & 2.9 \\
\hline Hinds & 258.3 & 63.4 & 61.4 & 2.0 & 78.0 & 56.4 & 21.6 & 116.9 & 78.3 & 38.6 \\
\hline Holmes & 275.6 & 78.2 & 75.5 & 2.7 & 90.1 & 62.1 & 28.0 & 107.3 & 78.6 & 28.7 \\
\hline Humphreys & 110.6 & $\cdots$ & & $\cdots$ & 16.2 & 16.2 & $\cdots$ & 94.4 & 76.6 & 17.8 \\
\hline Issaquena & 308.5 & 16.2 & & 16.2 & 69.5 & 22.7 & 46.8 & 222.8 & 82.1 & 140.7 \\
\hline Itawamba & 192.3 & 40.3 & 39.9 & .4 & 77.6 & 53.7 & 23.9 & 74.4 & 31.3 & 43.1 \\
\hline Jackson & 623.5 & 349.8 & 325.7 & 24.1 & 218.8 & 174.0 & 44.8 & 54.9 & 40.3 & 14.6 \\
\hline Jasper & 755.5 & 512.2 & 501.9 & 10.3 & 147.0 & 93.0 & 54.0 & 96.3 & 48.3 & 48.0 \\
\hline Jefferson & 717.7 & 521.2 & 310.6 & 210.6 & 102.0 & 54.6 & 47.4 & 94.5 & 41.3 & 53.2 \\
\hline Jefferson Davis & 177.3 & 79.3 & 79.3 & $\ldots$ & 48.4 & 35.5 & 12.9 & 49.6 & 26.5 & 23.1 \\
\hline Jones & 367.2 & 260.6 & 260.6 & $\ldots$ & 33.6 & 28.3 & 5.3 & 73.0 & 52.9 & 20.1 \\
\hline Kemper & 380.2 & 255.6 & 255.6 & $\ldots$ & 58.7 & 56.4 & 2.3 & 65.9 & 38.7 & 27.2 \\
\hline Lafayette & 430.5 & 162.8 & 162.8 & $\ldots$ & 61.7 & 55.1 & 6.6 & 206.0 & 160.1 & 45.9 \\
\hline Lamar & 388.8 & 318.4 & 318.4 & $\ldots$ & 52.4 & 19.5 & 32.9 & 18.0 & 11.3 & 6.7 \\
\hline Lauderdale & 454.2 & 323.7 & 323.7 & $\ldots$ & 49.0 & 40.2 & 8.8 & 81.5 & 49.1 & 32.4 \\
\hline Lawrence . & 295.9 & 144.4 & 144.4 & .. & 34.8 & 30.0 & 4.8 & 116.7 & 61.4 & 55.3 \\
\hline Leake & 234.8 & 155.3 & 155.3 & $\ldots$ & 33.6 & 29.7 & 3.9 & 45.9 & 40.3 & 5.6 \\
\hline Lee & 51.5 & 24.3 & 24.3 & $\ldots$ & 3.0 & 1.7 & 1.3 & 24.2 & 16.9 & 7.3 \\
\hline Leflore & 80.0 & & & $\ldots$ & 21.3 & 21.3 & $\ldots$ & 58.7 & 27.5 & 31.2 \\
\hline Lincoln & 418.5 & 245.8 & 244.3 & 1.5 & 70.0 & 39.1 & 30.9 & 102.7 & 58.9 & 43.8 \\
\hline Lowndes & 128.5 & 47.6 & 24.7 & 22.9 & 31.4 & 25.4 & 6.0 & 49.5 & 25.0 & 24.5 \\
\hline
\end{tabular}


Table 4. Sawtimber volume by species group and county (Continued)

\begin{tabular}{|c|c|c|c|c|c|c|c|c|c|c|}
\hline \multirow[b]{2}{*}{ County } & \multirow{2}{*}{$\underset{\text { species }}{\text { All }}$} & \multicolumn{3}{|c|}{ Softwood } & \multicolumn{3}{|c|}{$\begin{array}{c}\text { Soft } \\
\text { hardwood }\end{array}$} & \multicolumn{3}{|c|}{$\begin{array}{c}\text { Hard } \\
\text { hardwood }\end{array}$} \\
\hline & & Total & Pine & Other & Total & Gum & Other $^{1}$ & Total & Oak & Other $^{2}$ \\
\hline & \multicolumn{10}{|c|}{------------- Million board feet $-----------\cdots$} \\
\hline Madison & 268.5 & 112.9 & 107.1 & 5.8 & 51.7 & 45.4 & 6.3 & 103.9 & 69.8 & 34.1 \\
\hline Marion & 474.7 & 271.2 & 271.2 & $\ldots$ & 86.7 & 67.4 & 19.3 & 116.8 & 78.9 & 37.9 \\
\hline Marshall & 257.2 & 49.1 & 43.8 & 5.3 & 88.2 & 47.1 & 41.1 & 119.9 & 98.4 & 21.5 \\
\hline Monroe & 185.8 & 85.3 & 85.3 & $\ldots$ & 29.1 & 27.1 & 2.0 & 71.4 & 48.5 & 22.9 \\
\hline Montgomery & 96.4 & 48.5 & 48.5 & $\ldots$ & 4.1 & 4.1 & $\ldots$ & 43.8 & 29.1 & 14.7 \\
\hline Neshoba & 471.2 & 220.2 & 220.2 & $\ldots$ & 120.5 & 113.5 & 7.0 & 130.5 & 103.3 & 27.2 \\
\hline Newton & 245.7 & 100.2 & 100.2 & $\ldots$ & 44.4 & 33.2 & 11.2 & 101.1 & 69.7 & 31.4 \\
\hline Noxubee & 342.7 & 233.0 & 231.5 & 1.5 & 9.3 & 9.3 & $\ldots$ & 100.4 & 69.2 & 31.2 \\
\hline Oktibbeha & 162.0 & 117.0 & 111.8 & 5.2 & 2.5 & $\ldots$ & 2.5 & 42.5 & 34.1 & 8.4 \\
\hline Panola & 89.5 & 1.0 & & 1.0 & 31.9 & 24.7 & 7.2 & 56.6 & 36.4 & 20.2 \\
\hline Pearl River & 556.2 & 412.6 & 412.6 & $\ldots$ & 117.9 & 43.0 & 74.9 & 25.7 & 20.6 & 5.1 \\
\hline Perry & 565.6 & 482.7 & 479.9 & 2.8 & 43.3 & 38.5 & 4.8 & 39.6 & 32.6 & 7.0 \\
\hline Pike & 242.6 & 86.4 & 86.4 & $\ldots$ & 56.2 & 50.3 & 5.9 & 100.0 & 69.4 & 30.6 \\
\hline Pontotoc & 101.3 & 53.8 & 53.8 & 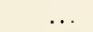 & 6.9 & 6.9 & $\ldots$ & 40.6 & 20.8 & 19.8 \\
\hline Prentiss & 53.6 & 11.7 & 11.7 & $\ldots$ & 10.4 & 8.8 & 1.6 & 31.5 & 26.6 & 4.9 \\
\hline Quitman & 77.4 & 11.5 & $\ldots$ & 11.5 & 36.2 & 25.6 & 10.6 & 29.7 & 10.4 & 19.3 \\
\hline Rankin & 597.7 & 314.2 & 297.1 & 17.1 & 51.1 & 49.1 & 2.0 & 232.4 & 160.2 & 72.2 \\
\hline Scott & 471.4 & 369.8 & 369.8 & & 49.2 & 49.2 & $\ldots$ & 52.4 & 38.1 & 14.3 \\
\hline Sharkey & 167.8 & 11.7 & & 11.7 & 33.9 & 33.9 & $\ldots$ & 122.2 & 86.1 & 36.1 \\
\hline Simpson & 312.1 & 182.5 & 182.5 & $\ldots$ & 51.0 & 48.9 & 2.1 & 78.6 & 59.7 & 18.9 \\
\hline Smith & 347.7 & 270.4 & 270.4 & $\ldots$ & 33.9 & 29.9 & 4.0 & 43.4 & 34.1 & 9.3 \\
\hline Stone & 360.6 & 265.9 & 261.3 & 4.6 & 71.7 & 30.3 & 41.4 & 23.0 & 22.1 & .9 \\
\hline Sunflower & 26.1 & 15.1 & $\ldots$ & 15.1 & 2.2 & ... & 2.2 & 8.8 & 8.8 & $\ldots$ \\
\hline Tallahatchie & 145.7 & 28.7 & 18.3 & 10.4 & 38.1 & 38.1 & & 78.9 & 49.6 & 29.3 \\
\hline Tate & 80.3 & $\ldots$ & & $\ldots$ & 48.4 & 34.7 & 13.7 & 31.9 & 4.7 & 27.2 \\
\hline Tippah & 105.9 & 27.4 & 27.4 & $\ldots$ & 23.6 & 19.0 & 4.6 & 54.9 & 42.1 & 12.8 \\
\hline Tishomingo & 263.1 & 138.5 & $138.5^{\circ}$ & $\ldots$ & 54.8 & 43.2 & 11.6 & 69.8 & 52.4 & 17.4 \\
\hline Tunica & 252.5 & 14.3 & $\ldots$ & 14.3 & 145.4 & 10.0 & 135.4 & 92.8 & 7.2 & 85.6 \\
\hline Union & 145.4 & 57.3 & 57.3 & $\ldots$ & 42.0 & 24.2 & 17.8 & 46.1 & 33.7 & 12.4 \\
\hline Walthall & 156.3 & 72.1 & 58.2 & 13.9 & 68.7 & 56.5 & 12.2 & 15.5 & 11.4 & 4.1 \\
\hline Warren & 597.3 & 30.7 & 24.4 & 6.3 & 286.6 & 125.9 & 160.7 & 280.0 & 136.3 & 143.7 \\
\hline Washington & 206.8 & 2.5 & & 2.5 & 109.5 & 30.1 & 79.4 & 94.8 & 38.4 & 56.4 \\
\hline Wayne & 732.5 & 598.2 & 598.2 & $\ldots$ & 59.5 & 44.9 & 14.6 & 74.8 & 53.5 & 21.3 \\
\hline Webster & 99.3 & 63.1 & 63.1 & $\ldots$ & 8.8 & 1.8 & 7.0 & 27.4 & 25.2 & 2.2 \\
\hline Wilkinson & 869.1 & 588.1 & 545.2 & 42.9 & 78.5 & 68.4 & 10.1 & 202.5 & 84.6 & 117.9 \\
\hline Winston & 524.2 & 261.3 & 261.3 & $\ldots$ & 111.1 & 90.7 & 20.4 & 151.8 & 119.1 & 32.7 \\
\hline Yalobusha & 107.1 & 32.9 & 31.9 & 1.0 & 10.0 & 8.2 & 1.8 & 64.2 & 54.4 & 9.8 \\
\hline Yazoo & 409.0 & 17.7 & 6.7 & 11.0 & 116.3 & 84.3 & 32.0 & 275.0 & 129.8 & 145.2 \\
\hline All counties & $25,546.7$ & $13,537.4$ & $12,972.3$ & 565.1 & $5,052.8$ & $3,253.0$ & $1,799.8$ & $6,956.5$ & $4,274.6$ & $2,681.9$ \\
\hline
\end{tabular}

1 Includes cottonwood, willow, yellow-poplar, and the like.

${ }^{2}$ Includes ash, hickory, sycamore, and the like. 
Table 5. Sawtimber volume by diameter group and county

\begin{tabular}{|c|c|c|c|c|c|c|c|c|c|c|}
\hline \multirow[b]{2}{*}{ County } & \multirow[b]{2}{*}{$\begin{array}{c}\text { All } \\
\text { species }\end{array}$} & \multicolumn{3}{|c|}{ Softwood } & \multicolumn{3}{|c|}{ Soft hardwood } & \multicolumn{3}{|c|}{ Hard hardwood } \\
\hline & & Total & $\begin{array}{l}10-14 \\
\text { inches }\end{array}$ & $\begin{array}{l}16 \text { inches } \\
\text { and up }\end{array}$ & Total & $\begin{array}{l}12-14 \\
\text { inches }\end{array}$ & $\begin{array}{l}16 \text { inches } \\
\text { and up }\end{array}$ & Total & $\begin{array}{l}12-14 \\
\text { inches }\end{array}$ & $\begin{array}{l}16 \text { inches } \\
\text { and up }\end{array}$ \\
\hline & -- & --- & --- & $----M$ & llion $b$ & ard fee & ---- & --- & ---1 & -- \\
\hline Adams & 493.2 & 155.2 & 45.7 & 109.5 & 141.7 & 20.6 & 121.1 & 196.3 & 63.2 & 133.1 \\
\hline Alcorn & 102.5 & 21.1 & 17.2 & 3.9 & 31.0 & 20.8 & 10.2 & 50.4 & 30.7 & 19.7 \\
\hline Amite & 501.8 & 394.6 & 190.6 & 204.0 & 23.0 & 17.6 & 5.4 & 84.2 & 35.8 & 48.4 \\
\hline Attala & 160.3 & 50.9 & 40.1 & 10.8 & 43.7 & 20.9 & 22.8 & 65.7 & 38.7 & 27.0 \\
\hline Benton & 147.3 & 78.0 & 78.0 & & 24.6 & 13.1 & 11.5 & 44.7 & 31.9 & 12.8 \\
\hline Bolivar & 240.7 & 39.7 & 12.5 & 27.2 & 143.3 & 23.1 & 120.2 & 57.7 & 11.8 & 45.9 \\
\hline Calhoun & 234.6 & 92.1 & 83.8 & 8.3 & 48.7 & 30.5 & 18.2 & 93.8 & 35.4 & 58.4 \\
\hline Carroll & 176.8 & 7.5 & 5.2 & 2.3 & 44.7 & 31.6 & 13.1 & 124.6 & 51.9 & 72.7 \\
\hline Chickasaw & 72.1 & 44.3 & 26.5 & 17.8 & 2.9 & 1.1 & 1.8 & 24.9 & 13.8 & 11.1 \\
\hline Choctaw & 140.7 & 91.7 & 65.5 & 26.2 & 28.1 & 23.3 & 4.8 & 20.9 & 17.1 & 3.8 \\
\hline Claiborne & 501.8 & 56.6 & 23.6 & 33.0 & 220.3 & 60.6 & 159.7 & 224.9 & 101.6 & 123.3 \\
\hline Clarke & 735.9 & 597.5 & 382.2 & 215.3 & 65.5 & 42.2 & 23.3 & 72.9 & 36.1 & 36.8 \\
\hline Clay & 192.5 & 19.6 & 16.3 & 3.3 & 15.7 & 8.0 & 7.7 & 157.2 & 93.4 & 63.8 \\
\hline Coahoma & 173.6 & 6.5 & 2.2 & 4.3 & 49.0 & 22.3 & 26.7 & 118.1 & 36.8 & 81.3 \\
\hline Copiah & 701.7 & 480.2 & 129.6 & 350.6 & 86.7 & 41.9 & 44.8 & 134.8 & 46.4 & 88.4 \\
\hline Covington & 201.3 & 63.7 & 32.6 & 31.1 & 85.5 & 38.8 & 46.7 & 52.1 & 25.2 & 26.9 \\
\hline De Soto & 130.3 & 5.6 & 2.5 & 3.1 & 41.8 & 17.3 & 24.5 & 82.9 & 35.2 & 47.7 \\
\hline Forrest & 280.2 & 221.1 & 159.6 & 61.5 & 37.4 & 22.7 & 14.7 & 21.7 & 12.0 & 9.7 \\
\hline Franklin & 768.7 & 606.4 & 307.8 & 298.6 & 45.9 & 15.6 & 30.3 & 116.4 & 54.6 & 61.8 \\
\hline George & 430.2 & 299.2 & 202.3 & 96.9 & 87.9 & 42.8 & 45.1 & 43.1 & 18.4 & 24.7 \\
\hline Greene & 545.7 & 377.1 & 252.9 & 124.2 & 89.3 & 50.3 & 39.0 & 79.3 & 38.4 & 40.9 \\
\hline Grenada & 154.2 & 51.3 & 30.4 & 20.9 & 52.0 & 29.8 & 22.2 & 50.9 & 18.3 & 32.6 \\
\hline Hancock & 220.8 & 166.4 & 125.6 & 40.8 & 49.6 & 36.6 & 13.0 & 4.8 & 4.8 & \\
\hline Harrison & 422.1 & 352.5 & 274.0 & 78.5 & 63.8 & 31.0 & 32.8 & 5.8 & 4.1 & 1.7 \\
\hline Hinds & 258.3 & 63.4 & 39.3 & 24.1 & 78.0 & 48.7 & 29.3 & 116.9 & 48.6 & 68.3 \\
\hline Holmes & 275.6 & 78.2 & 64.0 & 14.2 & 90.1 & 20.3 & 69.8 & 107.3 & 49.3 & 58.0 \\
\hline Humphreys & 110.6 & $\ldots$ & $\ldots$ & $\ldots$ & 16.2 & 5.0 & 11.2 & 94.4 & 24.1 & 70.3 \\
\hline Issaquena & 308.5 & 16.2 & 1.3 & 14.9 & 69.5 & 6.7 & 62.8 & 222.8 & 45.7 & 177.1 \\
\hline Itawamba & 192.3 & 40.3 & 36.5 & 3.8 & 77.6 & 34.1 & 43.5 & 74.4 & 37.2 & 37.2 \\
\hline Jackson & 623.5 & 349.8 & 274.6 & 75.2 & 218.8 & 67.4 & 151.4 & 54.9 & 18.4 & 36.5 \\
\hline Jasper & 755.5 & 512.2 & 280.4 & 231.8 & 147.0 & 57.7 & 89.3 & 96.3 & 44.4 & 51.9 \\
\hline Jefferson & 717.7 & 521.2 & 212.8 & 308.4 & 102.0 & 40.4 & 61.6 & 94.5 & 25.2 & 69.3 \\
\hline Jefferson Davis & 177.3 & 79.3 & 48.4 & 30.9 & 48.4 & 35.9 & 12.5 & 49.6 & 24.6 & 25.0 \\
\hline Jones & 367.2 & 260.6 & 156.1 & 104.5 & 33.6 & 29.6 & 4.0 & 73.0 & 47.7 & 25.3 \\
\hline Kemper & 380.2 & 255.6 & 160.5 & 95.1 & 58.7 & 47.3 & 11.4 & 65.9 & 35.4 & 30.5 \\
\hline Lafayette & 430.5 & 162.8 & 125.0 & 37.8 & 61.7 & 25.2 & 36.5 & 206.0 & 65.1 & 140.9 \\
\hline Lamar & 388.8 & 318.4 & 235.4 & 83.0 & 52.4 & 30.2 & 22.2 & 18.0 & 7.2 & 10.8 \\
\hline Lauderdale & 454.2 & 323.7 & 274.4 & 49.3 & 49.0 & 34.2 & 14.8 & 81.5 & 54.9 & 26.6 \\
\hline Lawrence. & 295.9 & 144.4 & 102.8 & 41.6 & 34.8 & 26.0 & 8.8 & 116.7 & 44.1 & 72.3 \\
\hline Leake & 234.8 & 155.3 & 99.5 & 55.8 & 33.6 & 27.6 & 6.0 & 45.9 & 19.4 & 26.5 \\
\hline Lee & 51.5 & 24.3 & 7.5 & 16.8 & 3.0 & & 3.0 & 24.2 & 11.8 & 12.4 \\
\hline Leflore & 80.0 & $\ldots$ & $\ldots$ & $\ldots$ & 21.3 & 3.3 & 18.0 & 58.7 & 15.3 & 43.4 \\
\hline
\end{tabular}


Table 5. Sawtimber volume by diameter group and county (Continued)

\begin{tabular}{|c|c|c|c|c|c|c|c|c|c|c|}
\hline \multirow[b]{2}{*}{ County } & \multirow[b]{2}{*}{$\underset{\text { species }}{\text { All }}$} & \multicolumn{3}{|c|}{ Softwood } & \multicolumn{3}{|c|}{ Soft hardwood } & \multicolumn{3}{|c|}{ Hard hardwood } \\
\hline & & Total & $\begin{array}{l}10-14 \\
\text { inches }\end{array}$ & $\begin{array}{l}16 \text { inches } \\
\text { and up }\end{array}$ & Total & $\begin{array}{l}12-14 \\
\text { inches }\end{array}$ & $\begin{array}{l}16 \text { inches } \\
\text { and up }\end{array}$ & Total & $\begin{array}{c}12-14 \\
\text { inches }\end{array}$ & $\begin{array}{l}16 \text { inches } \\
\text { and up }\end{array}$ \\
\hline & \multicolumn{10}{|c|}{--------------- Million board feet ---------------} \\
\hline Lincoln & 418.5 & 245.8 & 115.8 & 130.0 & 70.0 & 45.0 & 25.0 & 102.7 & 42.2 & 60.5 \\
\hline Lowndes & 128.5 & 47.6 & 21.8 & 25.8 & 31.4 & 19.4 & 12.0 & 49.5 & 29.4 & 20.1 \\
\hline Madison & 268.5 & 112.9 & 69.0 & 43.9 & 51.7 & 11.0 & 40.7 & 103.9 & 52.1 & 51.8 \\
\hline Marion & 474.7 & 271.2 & 170.6 & 100.6 & 86.7 & 50.4 & 36.3 & 116.8 & 48.1 & 68.7 \\
\hline Marshall & 257.2 & 49.1 & 31.3 & 17.8 & 88.2 & 41.6 & 46.6 & 119.9 & 49.1 & 70.8 \\
\hline Monroe & 185.8 & 85.3 & 36.2 & 49.1 & 29.1 & 21.9 & 7.2 & 71.4 & 48.2 & 23.2 \\
\hline Montgomery & 96.4 & 48.5 & 27.7 & 20.8 & 4.1 & 4.1 & $\ldots$ & 43.8 & 25.4 & 18.4 \\
\hline Neshoba & 471.2 & 220.2 & 184.4 & 35.8 & 120.5 & 83.9 & 36.6 & 130.5 & 66.6 & 63.9 \\
\hline Newton & 245.7 & 100.2 & 81.0 & 19.2 & 44.4 & 29.5 & 14.9 & 101.1 & 36.2 & 64.9 \\
\hline Noxubee & 342.7 & 233.0 & 155.3 & 77.7 & 9.3 & 9.3 & $\ldots$ & 100.4 & 60.6 & 39.8 \\
\hline Oktibbeha & 162.0 & 117.0 & 64.4 & 52.6 & 2.5 & $\ldots$ & 2.5 & 42.5 & 15.2 & 27.3 \\
\hline Panola & 89.5 & 1.0 & 1.0 & & 31.9 & 10.8 & 21.1 & 56.6 & 21.5 & 35.1 \\
\hline Pearl River & 556.2 & 412.6 & 341.0 & 71.6 & 117.9 & 60.2 & 57.7 & 25.7 & 6.0 & 19.7 \\
\hline Perry & 565.6 & 482.7 & 286.9 & 195.8 & 43.3 & 30.4 & 12.9 & 39.6 & 24.3 & 15.3 \\
\hline Pike & 242.6 & 86.4 & 56.8 & 29.6 & 56.2 & 14.8 & 41.4 & 100.0 & 37.4 & 62.6 \\
\hline Pontotoc & 101.3 & 53.8 & 48.4 & 5.4 & 6.9 & & 6.9 & 40.6 & 24.3 & 16.3 \\
\hline Prentiss & 53.6 & 11.7 & 10.8 & .9 & 10.4 & 10.4 & $\ldots$ & 31.5 & 17.6 & 13.9 \\
\hline Quitman & 77.4 & 11.5 & $\ldots$ & 11.5 & 36.2 & 11.3 & 24.9 & 29.7 & 13.3 & 16.4 \\
\hline Rankin & 597.7 & 314.2 & 191.7 & 122.5 & 51.1 & 17.0 & 34.1 & 232.4 & 103.1 & 129.3 \\
\hline Scott & 471.4 & 369.8 & 217.6 & 152.2 & 49.2 & 39.7 & 9.5 & 52.4 & 34.2 & 18.2 \\
\hline Sharkey & 167.8 & 11.7 & & 11.7 & 33.9 & 11.3 & 22.6 & 122.2 & 24.2 & 98.0 \\
\hline Simpson & 312.1 & 182.5 & 108.9 & 73.6 & 51.0 & 35.1 & 15.9 & 78.6 & 53.1 & 25.5 \\
\hline Smith & 347.7 & 270.4 & 182.5 & 87.9 & 33.9 & 20.2 & 13.7 & 43.4 & 22.8 & 20.6 \\
\hline Stone & 360.6 & 265.9 & 173.5 & 92.4 & 71.7 & 48.6 & 23.1 & 23.0 & 11.9 & 11.1 \\
\hline Sunflower & 26.1 & 15.1 & 2.3 & 12.8 & 2.2 & 2.2 & & 8.8 & 4.8 & 4.0 \\
\hline Tallahatchie & 145.7 & 28.7 & 25.7 & 3.0 & 38.1 & 20.3 & 17.8 & 78.9 & 16.9 & 62.0 \\
\hline Tate & 80.3 & & & $\ldots$ & 48.4 & 22.8 & 25.6 & 31.9 & 18.5 & 13.4 \\
\hline Tippah & 105.9 & 27.4 & 27.4 & & 23.6 & 5.1 & 18.5 & 54.9 & 28.3 & 26.6 \\
\hline Tishomingo & 263.1 & 138.5 & 102.7 & 35.8 & 54.8 & 31.4 & 23.4 & 69.8 & 37.8 & 32.0 \\
\hline Tunica & 252.5 & 14.3 & 3.7 & 10.6 & 145.4 & 39.7 & 105.7 & 92.8 & 18.7 & 74.1 \\
\hline Union & 145.4 & 57.3 & 57.3 & $\ldots$ & 42.0 & 31.2 & 10.8 & 46.1 & 23.8 & 22.3 \\
\hline Walthall & 156.3 & 72.1 & 38.5 & 33.6 & 68.7 & 47.4 & 21.3 & 15.5 & 5.4 & 10.1 \\
\hline Warren & 597.3 & 30.7 & 4.3 & 26.4 & 286.6 & 76.6 & 210.0 & 280.0 & 79.2 & 200.8 \\
\hline Washington & 206.8 & 2.5 & .9 & 1.6 & 109.5 & 26.0 & 83.5 & 94.8 & 19.7 & 75.1 \\
\hline Wayne & 732.5 & 598.2 & 420.0 & 178.2 & 59.5 & 40.6 & 18.9 & 74.8 & 42.7 & 32.1 \\
\hline Webster & 99.3 & 63.1 & 52.0 & 11.1 & 8.8 & 4.1 & 4.7 & 27.4 & 15.2 & 12.2 \\
\hline Wilkinson & 869.1 & 588.1 & 264.3 & 323.8 & 78.5 & 38.6 & 39.9 & 202.5 & 53.4 & 149.1 \\
\hline Winston & 524.2 & 261.3 & 181.3 & 80.0 & 111.1 & 48.9 & 62.2 & 151.8 & 87.4 & 64.4 \\
\hline Yalobusha & 107.1 & 32.9 & 14.9 & 18.0 & 10.0 & 6.5 & 3.5 & 64.2 & 36.3 & 27.9 \\
\hline Yazoo & 409.0 & 17.7 & 5.3 & 12.4 & 116.3 & 31.4 & 84.9 & 275.0 & 66.6 & 208.4 \\
\hline Total & $25,546.7$ & $13,537.4$ & $8,402.4$ & $5,135.0$ & $5,052.8$ & $2,300.8$ & $2,752.0$ & $6,956.5$ & $2,895.8$ & $4,060.7$ \\
\hline
\end{tabular}


Table 6. Land area and commercial forest by county

\begin{tabular}{|c|c|c|c|c|c|c|c|}
\hline \multirow[t]{2}{*}{ County } & \multirow{2}{*}{$\begin{array}{c}\text { All land } \\
\begin{array}{c}\text { Thousand } \\
\text { acres }\end{array}\end{array}$} & \multicolumn{2}{|c|}{ Commercial forest } & \multirow[t]{2}{*}{ County } & \multirow{2}{*}{$\begin{array}{c}\text { All land } \\
\text { Thousand } \\
\text { acres }\end{array}$} & \multicolumn{2}{|c|}{ Commercial forest } \\
\hline & & $\begin{array}{c}\text { Thousand } \\
\text { acres }\end{array}$ & Percent & & & $\begin{array}{c}\text { Thousand } \\
\text { acres }\end{array}$ & Percent \\
\hline Adams & 286.7 & 216.8 & 75.6 & Lincoln & 375.0 & 234.4 & 62.5 \\
\hline Alcorn & 259.2 & 134.3 & 51.8 & Lowndes & 325.1 & 144.4 & 44.4 \\
\hline Amite & 466.6 & 304.2 & 65.2 & & & & \\
\hline Attala & 463.4 & 276.4 & 59.6 & $\begin{array}{l}\text { Madison } \\
\text { Marion }\end{array}$ & $\begin{array}{l}480.6 \\
352.0\end{array}$ & $\begin{array}{l}197.6 \\
239.4\end{array}$ & $\begin{array}{l}41.1 \\
68.0\end{array}$ \\
\hline Benton & 263.7 & 174.7 & 66.2 & Marshall & 443.6 & 184.7 & 41.6 \\
\hline Bolivar & 586.9 & 107.7 & 18.4 & Monroe & 492.2 & 264.7 & 53.8 \\
\hline Calhoun & 369.2 & 209.1 & 56.6 & Montgomery & 257.9 & 154.0 & 59.7 \\
\hline Carroll & 408.3 & 213.5 & 52.3 & Neshoba & 363.5 & 199.6 & 54.9 \\
\hline Chickasaw & 323.8 & 150.4 & 46.4 & Newton & 371.2 & 226.1 & 60.9 \\
\hline Choctaw & 266.9 & 185.6 & 69.5 & Noxubee & 444.8 & 214.4 & 48.2 \\
\hline Claiborne & 311.0 & 223.5 & 71.9 & & & & \\
\hline Clarke & 446.1 & 332.5 & 74.5 & Oktibbeha & 290.6 & 150.8 & 51.9 \\
\hline Clay & 265.0 & 121.0 & 45.7 & Panola & 436.5 & 135.3 & 31.0 \\
\hline Coahoma & 364.8 & 94.1 & 25.8 & Pearl River & 530.0 & 348.7 & $\begin{array}{l}31.0 \\
65.8\end{array}$ \\
\hline Copiah & 499.9 & 338.4 & 67.7 & Perry & 417.9 & 327.6 & 78.4 \\
\hline Covington & 266.2 & 149.1 & 56.0 & Pike & 262.4 & 142.0 & 54.1 \\
\hline De Soto & 283.5 & 74.7 & 26.3 & $\begin{array}{l}\text { Pontotoc } \\
\text { Prentiss }\end{array}$ & $\begin{array}{l}320.6 \\
267.5\end{array}$ & $\begin{array}{l}143.1 \\
137.0\end{array}$ & $\begin{array}{l}44.6 \\
51.2\end{array}$ \\
\hline $\begin{array}{l}\text { Forrest } \\
\text { Franklin }\end{array}$ & $\begin{array}{l}300.2 \\
363.5\end{array}$ & $\begin{array}{l}210.4 \\
288.2\end{array}$ & $\begin{array}{l}70.1 \\
79.3\end{array}$ & Quitman & 263.7 & 64.3 & 24.4 \\
\hline George & 307.8 & 251.5 & 81.7 & Rankin & 512.0 & 359.9 & 70.3 \\
\hline Greene & 465.9 & 390.4 & 83.8 & & & & \\
\hline Grenada & 251.0 & 165.8 & 66.1 & $\begin{array}{l}\text { Scott } \\
\text { Sharkey }\end{array}$ & $\begin{array}{l}393.6 \\
279.0\end{array}$ & $\begin{array}{l}253.8 \\
132.1\end{array}$ & $\begin{array}{l}64.5 \\
47.3\end{array}$ \\
\hline Hancock & 310.4 & 249.3 & 80.3 & Simpson & 375.7 & 252.8 & 67.3 \\
\hline Harrison & 374.4 & 285.4 & 76.2 & Smith & 410.9 & 258.0 & 62.8 \\
\hline Hinds & 561.3 & 241.9 & 43.1 & Stone & 286.7 & 247.2 & 86.2 \\
\hline Holmes & 489.0 & 222.9 & 45.6 & Sunflower & 443.5 & 49.3 & 11.1 \\
\hline Humphreys & 262.4 & 101.0 & 38.5 & Tallahatchie & 412.2 & 150.7 & 36.6 \\
\hline Issaquena & 265.6 & 160.7 & 60.5 & Tate & 245.1 & 68.7 & 28.0 \\
\hline Itawamba & 346.2 & 226.7 & 65.5 & Tippah & 297.0 & 162.4 & 54.7 \\
\hline & & & & Tishomingo & 288.6 & 195.2 & 67.6 \\
\hline Jackson & 476.2 & 380.2 & 79.8 & Tunica & 293.1 & 91.4 & 31.2 \\
\hline Jasper & 437.1 & 288.1 & 65.9 & & & & \\
\hline Jefferson & 332.8 & 231.4 & 69.5 & Union & 270.1 & 122.5 & 45.4 \\
\hline Jefferson Davis & 265.0 & 145.2 & 54.8 & & 257.9 & 133.6 & 51.8 \\
\hline Jones & 451.8 & 300.5 & 66.5 & $\begin{array}{l}\text { Waithan } \\
\text { Warren }\end{array}$ & 362.2 & $\begin{array}{l}130.0 \\
233.2\end{array}$ & 64.4 \\
\hline Kemper & 484.5 & 332.3 & 68.6 & $\begin{array}{l}\text { Washington } \\
\text { Wayne }\end{array}$ & $\begin{array}{l}465.9 \\
529.3\end{array}$ & $\begin{array}{l}108.3 \\
434.6\end{array}$ & $\begin{array}{l}23.2 \\
82.1\end{array}$ \\
\hline Lafayette & 387.8 & 236.3 & 60.9 & Webster & 266.2 & 176.5 & 66.3 \\
\hline Lamar & 320.0 & 248.3 & 77.6 & Wilkinson & 432.0 & 328.3 & 76.0 \\
\hline Lauderdale & 461.4 & 329.9 & 71.5 & Winston & 387.8 & 244.2 & 63.0 \\
\hline Lawrence : & 277.1 & 192.0 & 69.3 & & & & \\
\hline Leake & 375.0 & 224.4 & 59.8 & $\begin{array}{l}\text { Yalobusha } \\
\text { Yazoo }\end{array}$ & $\begin{array}{l}282.9 \\
600.4\end{array}$ & $\begin{array}{l}184.2 \\
307.1\end{array}$ & $\begin{array}{l}65.1 \\
51.1\end{array}$ \\
\hline $\begin{array}{l}\text { Lee } \\
\text { Leflore }\end{array}$ & $\begin{array}{l}291.2 \\
376.3\end{array}$ & $\begin{array}{l}88.4 \\
94.3\end{array}$ & $\begin{array}{l}30.4 \\
25.1\end{array}$ & All counties & $30,152.3$ & $17,193.6$ & 57.0 \\
\hline
\end{tabular}




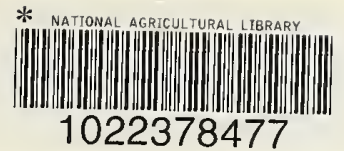


